INTERNATIONAL MONETARY FUND

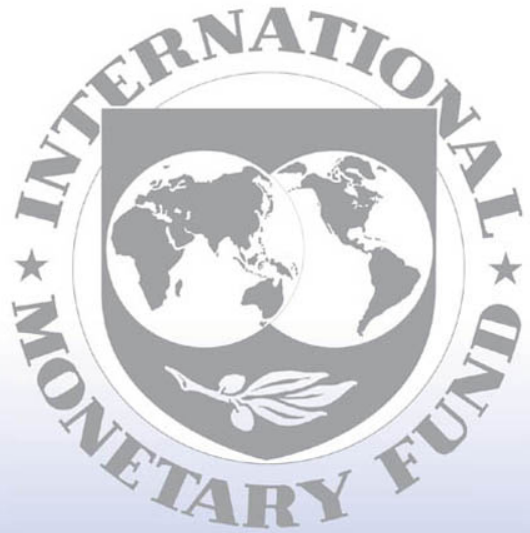

Staff

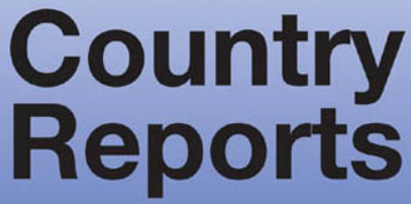




\title{
Republic of Congo: Enhanced Heavily Indebted Poor Countries Initiative- Completion Point Document and Multilateral Debt Relief Initiative
}

This paper was prepared by the staffs of the International Monetary Fund and the World Bank in connection with the Executive Board's consideration of the Republic of Congo's eligibility for assistance under the Enhanced Heavily Indebted Poor Countries Initiative. It is based on the information available at the time when it was completed on January 6, 2010. The views expressed in this document are those of the staff team and do not necessarily reflect the views of the Republic of Congo or the Executive Board of the IMF.

The policy of publication of staff reports and other documents by the IMF allows for the deletion of market-sensitive information.

\author{
Copies of this report are available to the public from \\ International Monetary Fund $\bullet$ Publication Services \\ 700 19th Street, N.W. • Washington, D.C. 20431 \\ Telephone: (202) 623-7430 • Telefax: (202) 623-7201 \\ E-mail: publications@imf.org • Internet: http://www.imf.org
}

\author{
International Monetary Fund \\ Washington, D.C.
}


INTERNATIONAL DEVELOPMENT ASSOCIATION AND

INTERNATIONAL MONETARY FUND

\author{
REPUBLIC OF CONGO
}

\title{
Enhanced Heavily Indebted Poor Countries (HIPC) Initiative Completion Point Document and Multilateral Debt Relief Initiative (MDRI)
}

Prepared by the Staffs of the International Development Association and the International Monetary Fund

Approved by Obiageli K. Ezekwesili and Otaviano Canuto (IDA)

Sharmini Coorey and Dhaneshwar Ghura (IMF)

January 6,2010 
Acronyms $\underline{4}$

Executive Summary $\underline{5}$

I. Introduction. $\underline{6}$

II. Assessment of Requirements for Reaching the Completion Point
A. PRSP and Poverty Monitoring.....
B. Macroeconomic Performance
C. Public Expenditure Prioritization.
D. Public Financial Management
E. Governance
F. Structural Reforms
$\frac{27}{27}$
G. Social Sector Reforms.
H. Debt Management..... .$\underline{29}$

III. Updated Debt Relief and Debt Sustainability Analysis .29

A. Data Reconciliation..............................................................................

B. Status of Creditor Participation in the Enhanced HIPC Initiative ...................

C. Debt Outlook after HIPC Assistance and Consideration for Exceptional

Topping-Up of HIPC Assistance. .$\underline{33}$

D. Creditor Participation in the Multilateral Debt Relief Initiative ..................... $\frac{35}{36}$

E. Debt Sustainability Outlook, 2009-28...................................................

F. Sensitivity Analysis ...................................................................

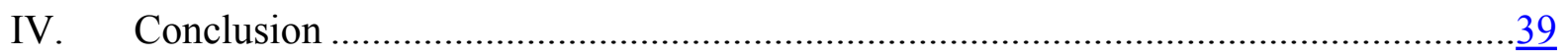

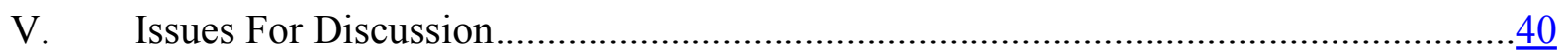

Boxes

1. Status of Floating Completion Point Triggers …................................................... $\frac{8}{8}$

2. Baseline Macroeconomic Assumptions ............................................................ 37

Figures

1. Composition of the Stock of External Debt by Creditor Group ................................41

2. External Debt and Debt Service Indicators for Medium-and Long-Term Public Sector Debt, 2009-28........................................................................ 42

3. Sensitivity Analysis, 2009-28 .................................................................

Tables

1. Revised Nominal Stocks and Net Present Value of Debt at Decision Point by Creditor Groups as of end-December 2004 
2. Estimated Assistance at Decision Point (Amended) ...................................................45

3. Comparison of Discount Rate and Exchange Rate Assumptions .................................46

4. Status of Creditor Participation Under the Enhanced HIPC Initiative ………..............47

5. Nominal and Net Present Value of External Debt Outstanding



6. Net Present Value of External Debt..................................................................

7. External Debt Service after Full Implementation of Debt-Relief Mechanisms.............50

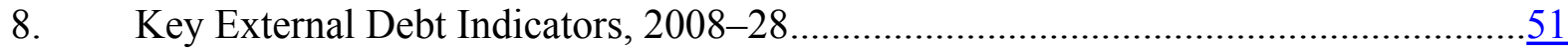

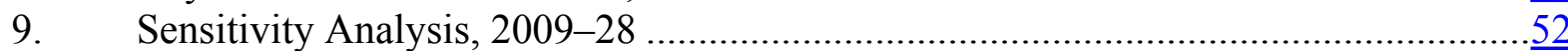

10. Delivery of IMF Assistance Under the Enhanced HIPC Initiative and the

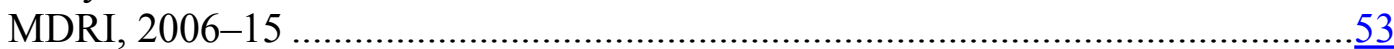

11. Delivery of World Bank HIPC Assistance and MDRI to 2006-44 .............................

12. Paris Club Creditors' Delivery of Debt Relief Under Bilateral Initiatives

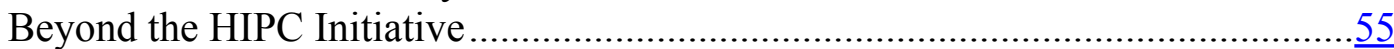

13. HIPC Initiative: Status of Country Cases under the Initiative, March 31, 2009 ......... $\underline{56}$

Appendices

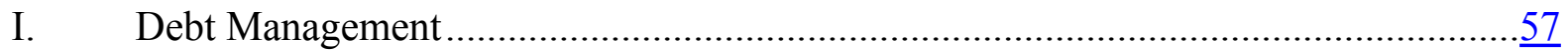

II. Debt Sustainability Analysis using the Low-Income Country Framework .................. 


\section{ACRONYMS}

\begin{tabular}{ll} 
AfDB & African Development Bank \\
AfDF & Africa Development Fund \\
APR & Annual Progress Report \\
ARMP & Agence de Regulation des Marchés Publics (Public Procurement Regulatory \\
& Authority) \\
ARV & Anti Retro Viral \\
BEAC & Banque des États de l'Afrique Centrale (Bank of Central African States) \\
CEMAC & Communauté Économique Monétaire de l'Afrique Centrale \\
& (Central African Economic and Monetary Community) \\
CFAA & Country Financial Accountability Assessment \\
DGMP & Public Procurement General Directorate \\
DMFAS & Debt Management and Financial Analysis System \\
DSA & Debt Sustainability Analysis \\
DTIS & Diagnostic Trade Integration Study \\
EC & European Commission \\
EITI & Extractive Industries Transparency Initiative \\
EU & European Union \\
GDP & Gross Domestic Product \\
HIPC & Heavily Indebted Poor Countries \\
HIV/AIDS & Human Immunodeficiency Virus/Acquired Immunodeficiency Syndrome \\
IDA & International Development Association \\
IMF & International Monetary Fund \\
JSAN & Joint Staff Advisory Note \\
LDP & Letter of Development Policy \\
LICUS & Low Income Countries under Stress \\
MDGs & Millennium Development Goals \\
MDRI & Multilateral Debt Relief Initiative \\
NGO & Non-Governmental Organization \\
NPV & Net Present Value \\
PFM & Public Financial Management \\
PRGF & Poverty Reduction and Growth Facility \\
PRS & Poverty Reduction Strategy \\
PRSP & Poverty Reduction Strategy Paper \\
UN & United Nations \\
UNDP & United Nations Development Program \\
VAT & Value Added Tax \\
& \\
\hline
\end{tabular}




\section{EXECUTIVE SUMMARY}

In March 2006, the Executive Boards of IDA and the IMF agreed that the Republic of Congo (Congo) had met the requirements for reaching the decision point under the enhanced Initiative for Heavily Indebted Poor Countries (HIPC). The amount of debt relief committed at the decision point was US\$1,679 million in net present value (NPV) terms at the end of 2004, calculated to reduce the NPV of eligible external debt to below the threshold of 250 percent of fiscal revenue at end-2004.

In the view of the IDA and IMF staffs, Congo has fulfilled all of the conditions to reach the completion point. All key decisions, actions, and measures required to achieve the floating completion point triggers have been taken, including a satisfactory track record of implementation in public investment management, procurement, governance and anticorruption and oil sector management.

As a result of the debt reconciliation exercise for the completion point, the NPV of eligible external debt at end-2004 after traditional debt relief has been revised downward from US\$ 5.2 billion to US\$ 5.1 billion. The common reduction factor has declined from 32.4 percent to 31.1 percent. Consequently the required HIPC assistance in end-2004 NPV terms has been revised downward from US\$ 1,679 million at the decision point to US\$ 1,575 million. So far, financing assurances have been provided by creditors representing 80.6 percent of HIPC debt relief estimated at decision point.

Upon reaching the completion point under the enhanced HIPC Initiative, Congo will also qualify for additional debt relief under the Multilateral Debt Relief Initiative (MDRI). Debt relief under the MDRI would imply a stock of debt reduction of US\$ 177.7 million (net of HIPC assistance) in nominal terms, saving the country US\$ 201.3 million of debt service through 2043. This additional relief would be provided via debt stock reductions at the Completion Point by IDA (US\$ 161.2 million), the AfDB (US\$ 9.1 million), and the IMF (US\$ 7.4 million).

Full delivery of HIPC assistance together with additional bilateral assistance beyond HIPC and MDRI debt relief at the completion point would reduce Congo's external debt burden significantly. The NPV of debt-to-revenue ratio at end-2010 would drop to 39 percent and gradually fall over time under the baseline scenario.

The staffs recommend that the Executive Directors of IDA and the IMF approve the completion point for the Republic of Congo under the enhanced HIPC Initiative. 


\section{INTRODUCTION}

1. This paper discusses the Republic of Congo's (Congo) progress under the enhanced Initiative for Heavily Indebted Poor Countries (HIPC). In the view of the staffs of the International Development Association (IDA) and the International Monetary Fund (IMF), this progress is sufficient for recommending to their respective Boards of Executive Directors the approval of the completion point for Congo under the enhanced HIPC Initiative. The authorities have fully implemented the completion point triggers on the Poverty Reduction Strategy (PRS), macroeconomic stability, public financial management, governance, reforms in the health and education sectors, and debt management; and have also established a satisfactory track record of implementation in public investment management, procurement, and governance and oil sector management.

2. This paper builds on two HIPC progress reports, which were submitted for the Boards in May 2007 and October 2008, respectively. These progress reports highlighted both achievements and difficulties in meeting specific triggers and thereby helped build momentum in moving forward towards completion point.

\section{In March 2006, the Boards of Executive Directors of IDA and the IMF agreed} that Congo had met the requirements for reaching the HIPC decision point. The amount of debt relief committed at the decision point was US\$1,679 million in NPV terms, calculated to reduce the NPV of debt-to-fiscal revenue ratio below the threshold of 250 percent on the basis of end-December 2004 data. Such relief represented an overall reduction of 32.4 percent in the NPV of all public- and publicly-guaranteed external debt as of end-December 2004, after application of traditional debt relief mechanisms. At the same time, the two Boards approved interim debt relief to Congo. Executive Directors had determined that the floating completion point would be reached when the triggers in Box 3 of the Decision Point Document will have been met.

4. This paper is organized as follows. Section II assesses Congo's performance in meeting the requirements for reaching the completion point under the enhanced HIPC Initiative. Section III provides an updated debt relief and debt sustainability analysis (DSA), including the status of creditor participation, and delivery of debt relief under the HIPC and MDRI Initiatives. Section IV summarizes the main conclusions, and Section V presents issues for discussion by Executive Directors.

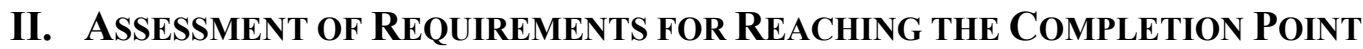

5. In the view of the staffs of IDA and the IMF, Congo has met in full all of the triggers for reaching the completion point (Box 1). All key decisions, actions, and measures required to observe the triggers have been taken, including a satisfactory track record of implementation for public investment management (trigger 4.ii), procurement (trigger 4.iii), governance and anti-corruption (trigger 5), improvement in the internal controls and accounting of the state-owned oil company (SNPC) (trigger 5.i), and oil 
commercialization (trigger 5.ii). To assess the performance of these specific triggers, the staffs and the authorities had agreed on a series of actions and indicators that would constitute satisfactory implementation as detailed below. 


\section{Box 1: Status of Floating Completion Point Triggers}

\begin{tabular}{|l|}
\hline \multicolumn{1}{|c|}{ Trigger } \\
\hline 1. PRSP: Preparation of a full PRSP through a participatory process and satisfactory \\
implementation of its recommended actions for at least one year, as evidenced by an Annual \\
Progress Report (APR) submitted by the government to the staffs of IDA and IMF.
\end{tabular}

2. Macroeconomic stability: Maintenance of macroeconomic stability as evidenced by satisfactory performance under the PRGF-supported program as well as any IMF successor program.

3. Public expenditure priorities: Alignment of public spending priorities in accordance with the priorities identified in the I-PRSP, and, when completed, the PRSP, reflecting emphasis on pro-poor growth.

\section{Public finance management:}

(i) Establishment of a functional classification system for government expenditures, including poverty related expenditures, consistent with the IMF's Government Finance Statistics manual, and preparation of government budgets using this new classification;

(ii) Implementation of a new public investment management system to provide rigorous selection, and efficient execution and monitoring of the projects; submission of draft public investment programs to IDA for review;

(iii) Adoption and satisfactory implementation by the government of a new procurement code (that promotes transparency and competition), in line with international best practice; and

(iv) Adoption by the government of a medium-term expenditure framework (MTEF) for sustainable management of government expenditures and revenues, with technical assistance from IDA and IMF.

\section{Governance and natural resource management}

Governance: Completion of a diagnostic governance and corruption study by an independent group of internationally reputed experts, assisted by a national anti-corruption committee, based on terms of reference prepared in consultation with IDA and IMF staffs. The terms of reference and composition of the national anti-corruption committee will be satisfactory to IDA and IMF staffs. Adoption by the government of an action plan, prepared in consultation with IDA and IMF staffs, to improve governance and reduce corruption, and sustained implementation of such action plan during the completion of the audits referenced in subsections 5 (i) and 5(ii). Assessment of the implementation of the action plan by IDA and IMF staffs on the basis of an independent review by international experts acceptable to IDA and the IMF.

Observed. APR submitted to Boards jointly with the Completion Point document.

Observed. $2^{\text {nd }}$ PRGF review completed on November 30, 2009; and staff's assessment is that the $3^{\text {rd }}$ review could be completed as envisaged in May 2010

Observed. Relative spending on propoor sectors has increased.

Observed. Budget 2009 prepared and executed with the new classification system.

Observed. Public investment management action plan and selected key measures implemented. Draft 2010 investment program submitted to IDA

Observed. New code adopted with application texts. New institutions established. The code has been satisfactorily implemented since October 2009.

Observed. Main elements of MTEF prepared and used as basis for preparation of draft budget 2010. An MTEF committee was formally created, and the government adopted an oil revenue model as basis for the MTEF projection.

Observed. Institutions established and diagnostic study completed. Anticorruption law and the anti-corruption action plan adopted and disseminated; agreed implementation steps taken. 


\begin{tabular}{|c|c|}
\hline \multicolumn{2}{|l|}{ Box 1 (cont.): Status of Floating Completion Point Triggers } \\
\hline Trigger & Status/comments \\
\hline $\begin{array}{l}\text { (ii) Preparation, by an independent firm of international reputation, of a diagnostic study of the } \\
\text { practices for the commercialization of oil by SNPC, based on terms of reference prepared in } \\
\text { consultation with IDA and IMF staffs. Assessment by IDA and IMF staffs, based on } \\
\text { successive audit opinions by an independent firm of international reputation, that the } \\
\text { commercialization of oil by SNPC has been brought into line with international best practice } \\
\text { on the basis of the recommendations of the diagnostic study, and results in competitive and } \\
\text { fair market values to Congo for the oil sold; and }\end{array}$ & $\begin{array}{l}\text { Observed. A diagnostic study was } \\
\text { completed in 2007, and an action } \\
\text { plan adopted in 2009. In the interim, } \\
\text { oil commercialization practices were } \\
\text { improved by increasing the number } \\
\text { of clients, ending prepayment of } \\
\text { cargos, and transferring receipts to } \\
\text { the treasury within } 15 \text { days. A new } \\
\text { set of procedures meeting } \\
\text { international standards was adopted, } \\
\text { an oil commercialization database } \\
\text { was established, and COTRADE was } \\
\text { integrated into SNPC. A statistical } \\
\text { analysis of data shows that prices } \\
\text { received by Congo on oil sales are } \\
\text { broadly in line with those of } \\
\text { international oil companies selling } \\
\text { similar oil on their own behalf. }\end{array}$ \\
\hline
\end{tabular}




\begin{tabular}{|c|c|}
\hline \multicolumn{2}{|l|}{ Box 1 (cont.): Status of Floating Completion Point Triggers } \\
\hline Trigger & Status/comments \\
\hline $\begin{array}{l}\text { Review of forestry sector management and legislation with IDA assistance; adoption by the } \\
\text { government of measures recommended by the review to promote competition, transparency, } \\
\text { and sustainable development in this sector. }\end{array}$ & $\begin{array}{l}\text { Observed. The review was } \\
\text { completed, the forestry code's fiscal } \\
\text { provisions were amended, and } \\
\text { decrees were adopted on i) } \\
\text { transparent competitive concession } \\
\text { award, ii) environmental and social } \\
\text { impact assessment iii) resolution of } \\
\text { conflicting usage of forest lands; and } \\
\text { iv) forest land gazetting procedures. } \\
\text { The fiscal reform package was } \\
\text { submitted to parliament. }\end{array}$ \\
\hline $\begin{array}{l}\text { 7. Social sectors: } \\
\text { Education: Implementation during } 2006 \text { of a strategy to eliminate fictitious workers from the } \\
\text { education budget and increase teacher staff by, at least, 1,000 each year in basic education } \\
\text { until } 2007 \text {. }\end{array}$ & $\begin{array}{l}\text { Observed. Census } \\
\text { recommendations implemented and } \\
\text { more than } 2000 \text { new teachers hired. }\end{array}$ \\
\hline $\begin{array}{l}\text { Health: Increase to, at least, } 60 \text { percent the share of generic drugs in total expenditures on } \\
\text { drugs by the central purchasing agency. }\end{array}$ & $\begin{array}{l}\text { Observed. Sufficient budget } \\
\text { allocations were made in } 2008 \text { and } \\
2009 \text {, although disbursements have } \\
\text { not been timely. An audit to improve } \\
\text { execution is planned. }\end{array}$ \\
\hline $\begin{array}{l}\text { 8. External debt management: } \\
\text { (i) Publication of the quarterly external debt data and projections on a government website; } \\
\text { and }\end{array}$ & $\begin{array}{l}\text { Observed. Quarterly data and } \\
\text { projections are available on the } \\
\text { Ministry of Finance, Budget, and } \\
\text { Public Portfolio web-site. }\end{array}$ \\
\hline $\begin{array}{l}\text { (ii) Centralization of all information on debt, including collateralized debt, in the government's } \\
\text { debt agency (CCA). }\end{array}$ & $\begin{array}{l}\text { Observed. All information on debt } \\
\text { centralized in the CCA. }\end{array}$ \\
\hline
\end{tabular}




\section{A. PRSP and Poverty Monitoring}

\section{Preparation of a full PRSP through a participatory process and satisfactory} implementation of its recommended actions for at least one year, as evidenced by an Annual Progress Report (APR) submitted by the government to the staffs of IDA and IMF.

6. Staffs consider this trigger as met, since a full PRSP was adopted in April 2008 and satisfactorily implemented since then. The PRSP is an important step in consolidating the country's effort toward achieving macroeconomic stability, strengthening economic governance, and program ownership. It represents the first comprehensive national development plan since the end of civil war in 2001 and has been instrumental in guiding Congo's policy framework. The PRSP's main elements include the need to: (i) improve governance and consolidate peace and security; (ii) promote growth and macroeconomic stability; (iii) enhance access to basic social services; (iv) improve the social environment and integration of vulnerable groups into society; and (v) combat HIV/AIDS.

\section{Staffs believe that the PRSP provided a sound basis for strengthening and} diversifying the economy and reducing poverty. ${ }^{1}$ The strategy derives part of its strength from the broad and inclusive preparation process, which involved a series of consultations in different regions with stakeholders from civil society, NGOs, and the private sector. The JSAN also commended the comprehensive poverty diagnosis on which the PRSP was based and welcomed the main elements as appropriate for the country's development objectives. In a number of areas, needed improvements were identified by the staffs in the JSAN.

\section{The 2006 poverty assessment (based on the 2005 poverty survey) significantly} enhanced the understanding the causes, extent and distribution of poverty in Congo, yet will have to be strengthened and updated in the run up to the second PRSP. The 2005 poverty survey had revealed that just over 50 percent of Congolese households live below the poverty line; and that the highest poverty incidence is found in semi-urban and rural areas and almost 60 percent of poor households are headed by women. A new assessment has been launched, which includes a second poverty survey aimed at producing comparable household and expenditure data. This will be critical for strengthening the availability and quality of poverty and social data.

9. Concerning poverty monitoring, efforts for strengthening statistical capacity are underway with an important first step being the adoption of a new statistical framework law in July 2009. This law aims at reorganizing the institutional set-up for collection, treatment and analysis of statistical information, and, in particular enhancing statistical coordination across the public administration. To operationalize the law, a new statistics strategy is being prepared. This is expected to clarify roles and build the capacity of institutions involved in data collection and analysis, which is an important reform area

\footnotetext{
${ }^{1}$ The IDA Executive Directors discussed the PRSP and the Joint Staff Advisory Note (JSAN) in October 2008. Both documents were circulated to IMF Executive Directors for information.
} 
identified in the JSAN. In this regard statistical capacity should be improved in sector ministries as well and data used for monitoring PRSP implementation should also cover administrative elements, such as outputs from public or private sector entities.

\section{Staffs consider that the implementation of the PRSP was satisfactory, as} discussed by the JSAN on the Annual Progress Report (APR). The 2009 APR was adopted by the government in August 2009 and circulated to the Fund and IDA Boards together with this document. The JSAN notes that Congo has continued to progress with its PRSP implementation and it has not been deterred by the global financial crisis. Indeed, the difficult external environment has strengthened the authorities' resolve to diversify the economy, consolidate the fiscal position, and accelerate efforts to rehabilitate the economic infrastructure. Structural reforms have been stepped up, in particular, to enhance public financial management (adoption of a new procurement code, introduction of an MTEF, and a simplified expenditure chain). The APR reflects these advances and incorporates a number of refinements made to the PRSP in the past few months. The APR also lays out a program for further strengthening the strategy, in particular for the monitoring and evaluation (M\&E) framework and the statistical basis in order to monitor progress.

\section{B. Macroeconomic Performance}

Maintenance of macroeconomic stability as evidenced by satisfactory performance under the PRGF-supported program as well as any IMF successor program.

\section{Staffs consider this trigger as met, as performance under the PRGF} arrangement has been satisfactory since its approval in December 2008. The completion of the second review on November 30, 2009 and the fact that the program has remained on track since then, provides a track record of satisfactory performance. Economic policy implementation has strengthened during the past two years, due to closer program monitoring by the authorities and stronger ownership. This has led to an improvement in macroeconomic performance, although the global financial crisis has adversely affected external demand and weakened activity in the non-oil economy this year (Text Table 1). Overall real GDP growth is expected to expand by about $71 / 2$ percent this year increasing to double digits next year, alongside the recovery of the world economy and higher oil production from new fields. Inflation has been above the CEMAC convergence criteria during the past year or more but is trending downward and is projected to fall to about 3 percent by the end of 2010 .

\section{Preliminary fiscal data for end-November 2009 indicate the program remains on} track and the third PRGF review is expected to be completed as envisaged in May 2010. Some budget overruns emerged at end September (equivalent to about 2.6 percent of non-oil GDP) due to the transition to a new government (which took office in late September) and an acceleration of some domestic public investment to take advantage of favorable weather in the dry season. However, these overruns were addressed by end November through the authorities' efforts to maintain strong non-oil tax revenue collections; a stoppage in spending authorizations in mid-November, which allowed only non-discretionary payments to continue to avoid domestic arrears accumulation; and the drawdown of HIPC resources to 
finance capital expenditure in line with the envisaged use of these funds (the use of HIPC, rather than domestic resources, has the impact of reducing the non-oil primary deficit under the program). The non-oil primary fiscal deficit was slightly below the program path at end November (by about CFAF 4 billion) and staff projects the under-execution of the budget to continue through December, enabling the authorities to achieve the program's year-end performance criterion, excluding any outlays to address a refugee crisis in the northeast part of the county. ${ }^{2}$ Indications are that the structural measures under the program are also on track.

13. The fiscal position has improved significantly since the decision point. The basic non-oil primary deficit reached 55.7 percent of non-oil GDP in 2007 but has since declined sharply, and is projected at about 37.3 percent of non-oil GDP in 2009, owing to strong tax revenue collection and expenditure discipline. The tightening of the fiscal stance has not inhibited the increase in pro-growth and pro-poor spending.

\section{The external sector has experienced a mixed performance during the past} several years, largely on account of developments in the oil sector. The external current account has been in deficit since 2007 reflecting the volatility of world oil prices and technical problems that have led to fluctuations in oil production. On the other hand, external indebtedness has been reduced significantly, on account of debt rescheduling and relief from the Paris Club, non-Paris Club creditors, and London Club creditors on favorable terms.

Text Table 1. Republic of Congo: Selected Macroeconomic Indicators, 2004-09

\begin{tabular}{|c|c|c|c|c|c|c|}
\hline & 2004 & 2005 & 2006 & 2007 & 2008 & $\begin{array}{r}2009 \\
\text { (Proj.) }\end{array}$ \\
\hline & \multicolumn{6}{|c|}{ (Annual percentage change, unless otherwise indicated) } \\
\hline \multicolumn{7}{|l|}{ Economic growth and prices } \\
\hline Real GDP & 3.5 & 7.8 & 6.2 & -1.6 & 5.6 & 7.6 \\
\hline Oil & 0.5 & 12.5 & 6.8 & -17.2 & 6.1 & 17.5 \\
\hline Non-oil & 5.0 & 5.4 & 5.9 & 6.6 & 5.4 & 3.5 \\
\hline Consumer prices (end-of-period) & 1.1 & 3.1 & 8.1 & -1.7 & 11.4 & 3.2 \\
\hline \multicolumn{7}{|l|}{ External sector } \\
\hline Exports, f.o.b (CFA francs) & 4.9 & 53.8 & 30.0 & -12.3 & 24.0 & -20.1 \\
\hline Imports, f.o.b (CFA francs) & 16.4 & 34.3 & 42.9 & 5.1 & 24.7 & -8.7 \\
\hline Export volume & -1.5 & 12.1 & 5.4 & -16.9 & 7.2 & 16.1 \\
\hline Import volume & 12.1 & 20.0 & 32.2 & 4.2 & 15.2 & 1.9 \\
\hline \multirow[t]{2}{*}{$\begin{array}{l}\text { Current account balance } \\
\text { (including grants, in percent of GDP) }\end{array}$} & -7.3 & 2.2 & 1.5 & -9.3 & -1.5 & -14.8 \\
\hline & \multicolumn{6}{|c|}{ (Percent of non-oil GDP) } \\
\hline \multicolumn{7}{|l|}{ Government finance } \\
\hline Revenue and grants & 69.9 & 108.2 & 141.5 & 113.5 & 159.3 & 87.4 \\
\hline Oil revenue & 49.7 & 88.6 & 120.6 & 92.3 & 136.0 & 62.7 \\
\hline Non-oil revenue and grants & 19.5 & 19.6 & 20.9 & 21.2 & 23.3 & 24.7 \\
\hline Total expenditure & 61.6 & 67.4 & 88.8 & 86.3 & 79.5 & 71.5 \\
\hline $\begin{array}{l}\text { Overall balance } \\
\text { (including grants, commitment basis) }\end{array}$ & 8.4 & 40.8 & 52.7 & 27.1 & 79.8 & 15.9 \\
\hline Non-oil primary basic balance $(-=$ deficit $)$ & -25.9 & -29.6 & -51.3 & -55.7 & -44.3 & -37.3 \\
\hline
\end{tabular}

\footnotetext{
${ }^{2}$ The fiscal situation at end 2009 and beyond could be adversely affected by a refugee crisis that has worsened recently; the UN estimates that more than 90,000 people have entered Congo to avoid ethnic violence in the Democratic Republic of Congo. The Congolese authorities have provided resources to alleviate the situation, and they and the staff are monitoring developments closely; through the end of November, CFAF 2 billion has been disbursed to address the situation.
} 


\section{Public Expenditure Prioritization}

Alignment of public spending priorities in accordance with the priorities identified in the IPRSP, and, when completed, the PRSP, reflecting emphasis on pro-poor growth.

\section{Staffs consider this trigger as met, since public spending is now better aligned} with the priorities identified in the PRSP. Pro-poor expenditure increased from 4.1 percent of GDP in 2003 to 7.0 percent in 2008 (Text Table 2). Indeed, the proportion of pro-poor expenditure in total public expenditure continued to increase gradually from 13.8 percent of total public expenditure in 2003 to 27.2 percent in 2008 (Text Table 3). Spending on power, water, sanitation, and infrastructure increased from 1.8 percent of GDP in 2005 to 3.4 percent in 2008. The envelope for basic health and education also expanded, but to a lesser extent, rising from 2.1 percent of GDP to 2.8 percent over the same period. In comparison, outlays for agriculture, employment and social protection remained constant as a share of GDP.

Text Table 2. Republic of Congo: Pro-poor Expenditure, 2003-08 (in percent of GDP)

\begin{tabular}{lcccccc}
\hline & 2003 & 2004 & 2005 & 2006 & 2007 & 2008 \\
\hline Basic health and HIVIAIDS & 0.2 & 0.4 & 0.6 & 1.0 & 0.9 & 1.2 \\
Basic education & 1.7 & 1.5 & 1.5 & 1.4 & 1.6 & 1.7 \\
Infrastructure & 0.3 & 1.2 & 1.2 & 1.2 & 1.6 & 2.4 \\
Power, water and sanitation & 0.9 & 0.3 & 0.6 & 1.1 & 2.3 & 1.1 \\
DDR and food for soldiers & 0.9 & 0.7 & 0.7 & 0.8 & 1.5 & 0.7 \\
Employment and social protection & 0.1 & 0.1 & 0.1 & 0.1 & 0.1 & 0.0 \\
Agriculture & 0.0 & 0.0 & 0.1 & 0.1 & 0.1 & 0.1 \\
Total & 4.1 & 4.2 & 4.8 & 5.7 & 8.0 & 7.0 \\
Memorandum item: & & & & & & \\
GDP (in billions of CFA) & 2,032 & 2,456 & 3,211 & 4,043 & 3,664 & 4,802 \\
\hline
\end{tabular}

Sources: Congolese authorities; World Bank and Fund staff estimates.

Text Table 3. Republic of Congo: Pro-poor Expenditure, 2003-08 (in percent of total public expenditure)

\begin{tabular}{lrrrrrr}
\hline & 2003 & 2004 & 2005 & 2006 & 2007 & 2008 \\
\hline Basic health and HIVIAIDS & 0.7 & 1.5 & 2.4 & 3.5 & 2.8 & 4.6 \\
Basic education & 5.6 & 5.6 & 6.2 & 5.3 & 4.9 & 6.4 \\
Infrastructure & 1.0 & 4.5 & 5.2 & 4.4 & 4.9 & 9.3 \\
Power, water and sanitation & 3.1 & 1.2 & 2.8 & 4.1 & 7.0 & 4.1 \\
DDR and food for soldiers & 3.0 & 2.6 & 3.2 & 2.8 & 4.6 & 2.7 \\
Employment and social protection & 0.4 & 0.2 & 0.4 & 0.2 & 0.2 & 0.1 \\
Agriculture & 0.0 & 0.1 & 0.5 & 0.4 & 0.2 & 0.6 \\
Total & 13.8 & 15.7 & 20.7 & 20.7 & 24.4 & 27.2 \\
Memorandum item: & & & & & & \\
Total public expenditure (in billions of CFAF) & 604 & 657 & 745 & 1,113 & 1,201 & 1,238 \\
\hline
\end{tabular}

Sources: Congolese authorities, World Bank and Fund staff estimates. 
16. The ongoing reform of public financial management (see below) is expected to improve monitoring of expenditure. The full PRSP provides medium-term public expenditure projections and identifies those that are pro-poor, although only at an aggregate level. The streamlining and computerization of the budget execution process, to be completed by the end of 2010, should allow for real-time tracking of all outlays, including the use of HIPC debt relief. The use of HIPC resources for public spending commenced in late 2008. These resources have been used to finance pro-growth and pro-poor spending in line with the Initiative.

17. The Government has continued to deposit interim HIPC assistance in the special Treasury account at the regional central bank (BEAC). The special account had an accumulated balance of CFAF 45.9 billion at end-2008 (about US\$ 104 million). In 2008 the authorities met all prerequisites to use the HIPC special account, as the Executive and Consultative Committees on use of HIPC resources are operational and an initial audit of the special account covering the period March 2006 to August 2007 revealed no major problems and confirmed that all the savings were deposited into the account. A second audit reviewed the accounting and use of HIPC funds during the period September 2007 to December 2008. This audit revealed that the savings deposited in the account were generally in order and confirmed the proper utilization of the funds, particularly as regards procurement and financial management. Its only recommendation concerned the need to institute a more regular record keeping on savings realized from debt relief.

18. The use of HIPC resources for public spending commenced only in late 2008, due to some delays in properly setting up the HIPC account. For the first time, the Government allocated CFAF 25 billion of these funds through the 2008 supplemental budget adopted by the Parliament in October 2008, and CFAF 7 billion were actually disbursed at end-year. In the 2009 budget, the interim HIPC relief allocation increased to CFAF 37 billion, composed of CFAF 19 billion for new projects and CFAF 18 billion for the unused budget in 2008 that was brought forward.

\section{Public Financial Management}

19. Staffs consider that the triggers in this area have been met. The adoption in 2008 of a Public Financial Management Improvement Action Plan (PAGGFP) and a Public Investment Management Action Plan (PAGGIP) are particularly important in this regard. These two documents constitute a strong basis for the introduction of fundamental reforms of the public financial management system.

20. These measures were recently complemented with the adoption earlier this year of a decree supporting the rationalization of budget execution procedures (expenditure chain) that will further strengthen reform. While not a trigger in itself, this decree provides a strong basis for implementing changes in public investment management and procurement. It will help to streamline procedures and controls at the commitment stage of the expenditure chain (engagement) and will be further developed through the 
computerization of the main elements of the public financial management system, which is important to enhancing transparency and predictability of expenditure procedures. In addition, a reform of the payment system (Treasury) is under design.

\section{Budget Classification}

Establishment of a functional classification system for government expenditures, including poverty related expenditures, consistent with the IMF's Government Finance Statistics manual, and preparation of government budgets using this new classification.

21. Staffs consider this trigger as met, as a functional classification system was fully effective at the beginning of this year and was used for preparing and executing the 2009 budget. The classification was reformed with technical assistance from the IMF and it is consistent with the Fund's 2001 Government Finance Statistics manual. The new classification system has been implemented at all levels of government. ${ }^{3}$

\section{Public Investment Management}

Implementation of a new public investment management system to provide rigorous selection, and efficient execution and monitoring of the projects; submission of draft public investment programs to IDA for review.

22. On the basis of the implementation record of the public investment management reform, staffs consider this trigger as being met. The authorities have put in place basic reform elements for turning Congo's public investment management into a transparent and effective system, which will appraise and select projects on their expected economic and social costs and benefits, as well as transparently and effectively implements the public investment budget, and closely monitors budget implementation and project execution. This being said, in order to complete and make the new system function well, reform efforts will have to continue, in particular as regards building institutional and human capacity.

\section{In December 2008, the Government adopted a public investment management} action plan. The plan was based on a detailed assessment on existing processes and capacity for managing public investments as well as an in-depth audit of the public investment budget execution in 2006, conducted in the context of the Bank's emergency recovery project. It outlines a comprehensive reform of the whole cycle of publicly funded projects, based on the following principles:

\footnotetext{
${ }^{3}$ The functional classification is used. The authorities are currently working with support from Fund staff to enhance the classification of pro-poor spending using this classification, which would allow for a better mapping from the budget to the PRSP.
} 
- Clarify roles and responsibilities of different actors in public investment management, notably a gradual decentralization that will over time provide the sector ministries with increased authority.

- Introduce a system that provides for a strategic selection of public investment projects, based on an appraisal process that objectively assesses economic, social and environmental costs and benefits.

- Integrate the public investment budget with the overall budget process through the MTEF, and thereby strengthen the multi-year planning horizon for public investments.

- $\quad$ Strengthen transparency and effectiveness in the execution of public investments, through ongoing reforms on procurement and expenditure chain.

24. Based on this comprehensive multi-year action plan, the government implemented a set of priority actions in 2009. These include:

- A decree clarifying the role of the Directors of Planning (DEP) in sector ministries was adopted in August 2009. This decree strengthens the position of the DEP in investment budget programming, project elaboration, appraisal, and monitoring of the investment budget, and project implementation.

- $\quad$ An indicative new budget calendar was adopted in August 2009. This calendar includes the preparation process for the tri-annual public investment program.

- A new system for appraising and selecting new projects has been introduced through a circular letter from the Minister of Planning. At the core of this new system is a project appraisal process that ensures that all projects eligible for budget financing comply with the following requirements: i) project objectives are consistent with national development objectives, ii) technical feasibility is considered, taking into account available resources, iii) costs are estimated in detail and there is evidence that the proposal constitutes a least-cost option, iv) socio-economic returns are considered, as well as social and environmental impact, and v) a credible implementation plan is presented. Project appraisals will be standardized, yet allow for flexibility in order to cater to project size and complexity.

- A project evaluation fund was established, which provides financing and technical support to project appraisals. A proposal on the design of this fund and its institutional anchoring has been adopted. The fund will be in place in early 2010 , ready for the preparation of a new project pipeline for the 2011 budget. In addition, the government met its commitment of providing adequate allocations for or financing of project appraisals in the 2009 and 2010 budgets and of subjecting all new projects larger than CFAF 500 million included in the draft 2010 budget to a technical and economic feasibility study. 
- $\quad$ A report on implementation of the investment budget in the first semester of 2009 was prepared, revealing significant improvements in respecting budget guidelines.

25. Draft public investment budgets have been submitted to IDA every year since the 2007 exercise, and staffs' comments have been taken into account. The exchange was particularly effective in the preparation of the 2009 and 2010 investment budgets, when staffs' detailed comments were shared with the parliament for the budget session.

\section{Procurement}

Adoption and satisfactory implementation by the government of a new procurement code (that promotes transparency and competition), in line with international best practice.

26. The staffs consider this trigger as met, since a new procurement code was adopted and implemented satisfactorily. The new procurement code was adopted in May 2009 with a legal and regulatory framework in line with international best practice. The administrative and institutional elements to support the new code have also been put in place including the relevant secondary legal acts; the creation and staffing of a general public procurement directorate (DGCMP), which is tasked with overall responsibility for public procurement policy; a regulatory authority (ARMP) to oversee the procurement function; and a contract management authority that will handle large and complex contracts on behalf of the contract authority.

\section{The authorities completed all of the administrative elements to support the} satisfactory implementation of the new code. The operational unit of the regulatory body that includes the general directorate and the bidders' complaint unit have been put in place to ensure that effective procedures are implemented for resolving disputes, and any other complaints that may arise during the procurement process. Procurement units have been set up in five line ministries that include Education, Health and Agriculture, and these units have been equipped and staffed.

28. To facilitate implementation, a manual of procedures for executing agencies, standard bidding documents, and a description of the general conditions of contracts have been prepared, and a training program is underway. All key staffs in the new procurement institutions are in position: the Director General of the procurement agency was appointed as the code's regulations require, three key technical directors were recruited, and over 100 trainers have been trained in the new procedures. The staffs judge that the capacity of the procurement agency in terms of processing time and compliance with standards is satisfactory, which has been demonstrated through the tendering of three contracts through 
the new system. ${ }^{4}$ These contract awards were made in full conformity with the legal and regulatory framework of the new code.

\section{Medium Term Expenditure Framework}

\section{Adoption by the government of a medium-term framework (MTEF) for sustainable management of government expenditures and revenues, with technical assistance from IDA and IMF.}

29. Staffs consider this trigger as met, since the main elements of a full MTEF are in place and it was used to prepare the 2010 budget. Recent developments include:

- $\quad$ Adjustments to the MTEF to ensure consistency with the macroeconomic framework underlying the authorities' PRGF arrangement and the draft 2010 budget. An internally consistent macroeconomic framework served as the starting point for the 2010 budget preparation. A technical committee comprising members of the Ministries of Planning and Finance and the BEAC has been established to prepare the macroeconomic framework (in consultation with Fund staff) going forward.

- $\quad$ On the basis of the macroeconomic framework, a central MTEF was prepared with indicative allocations for all sectors over the next three years. This central MTEF was attached to the APR, providing for the first time a comprehensive and coherent translation of the PRSP priorities into budgetary allocations.

- $\quad$ The authorities' progress in preparing sector MTEFs has exceeded expectations. These sector MTEFs contain sector-specific policy objectives, indicators to measure progress (along with targets), and a list of priority programs designed to meet these objectives. The programs are then broken down into specific activities with cost estimates. Initial efforts to develop sector MTEFs in education, health, transport, and agriculture were extended to all of the major ministries ( 20 in total). The efforts to broaden the MTEF are welcome, although detailed strategies and program and costs will need to be developed; such strategies exist now in the education, health, and transport sectors.

- Given the prominence of budgetary oil revenue, the adoption of a new oil revenue model is an important advancement for improving the quality of these projections. The model was developed by international experts using information on field reserves, production profiles, operating costs and oil prices collected from all operators or estimated by the Ministry of Hydrocarbons as necessary, in collaboration with the state-owned oil company. The model can simulate and forecast gross oil revenue received by the Treasury, crude oil transfers to the state-owned oil refinery to

\footnotetext{
${ }^{4}$ More than 300 contracts were sent back to the procuring ministries/agencies by the Director General of the procurement agency, for not complying with the requirements of the new code.
} 
supply the domestic market, SNPC costs to estimate net state revenue, as well as the projection of debt payments. For the implementation of the model, a team comprised of representatives of the concerned agencies was set up to install and manage the model. A core team of government officials has received extensive training and is now able to operate the model. Training activities will continue and will be extended to a wider group of users.

30. In the period ahead, the main challenge will be to further consolidate these elements with a view to ensuring the MTEF informs all future budgets. Among other things, this will require refining the sector MTEFs and full use of the oil revenue model. In this regard, making the inter-ministerial and technical committee permanent could facilitate these efforts.

\section{E. Governance}

\section{Governance and anti-corruption}

Completion of a diagnostic governance and corruption study by an independent group of internationally reputed experts, assisted by a national anti-corruption committee, based on terms of reference prepared in consultation with IDA and IMF staffs. The terms of reference and composition of the national anti-corruption committee will be satisfactory to IDA and IMF staffs. Adoption by the government of an action plan, prepared in consultation with IDA and IMF staffs, to improve governance and reduce corruption, and sustained implementation of such action plan during the completion of the audits referenced in subsections 5(i) and 5(ii). Assessment of the implementation of the action plan by IDA and IMF staffs on the basis of an independent review by international experts acceptable to IDA and the IMF.

31. Staffs consider this trigger as met, since the government has made substantial progress in strengthening the institutional framework for the fight against corruption and improving governance. A governmental Anti-corruption Commission has been established based on terms of reference agreed with IDA and IMF staffs, initially at the level of the Prime Minister, but now placed under the authority of the Presidency. Its mandate is the formulation, coordination and implementation of the government's anti-corruption strategy.

\section{An independent Anti-Corruption Observatory was established by law in} September 2007 and its members were nominated by government decree a month later. The Observatory is chaired by a representative of the ecumenical churches and more than half of its members come from civil society organizations (including trade unions and the EITI committee). The law provides the Observatory with a broad mandate to review governmental initiatives related to governance and corruption, including all audits of stateowned enterprises and procedures for issuing natural resource concessions. Due to the nature of its membership, the Observatory is able to perform its mandate independently, notably to 
critically assess the anti-corruption strategy implemented by the government. Both the Commission and the Observatory have a permanent secretariat located in their respective premises, although the offices of the Observatory are still being upgraded. Appropriate resources for the operational expenditures of both institutions were included in the 2008 and 2009 budgets, but disbursements have not been made in a timely manner.

\section{In February 2009, a diagnostic study on governance and corruption was} completed by a firm of international reputation. The study provides an in-depth assessment of perceived levels of corruption as well as their causes, and offers recommendations on how to address them. The diagnostic study served as the basis for the design of the government's Anti-Corruption action plan.

\section{The Anti-Corruption action plan was adopted by the government in August} 2009 and is currently being implemented, including through a communication program aimed at informing the relevant constituencies of its mandate and activities. The Action Plan was reviewed by an expert of international reputation in March 2009 and found to be satisfactory. The action plan highlighted five sectors most at risk of corruption: oil production and marketing, forestry, public financial management, justice and police, and the social sectors. The action plan addresses specifically each of these five priority sectors and includes actions to reduce the risk of corruption and to enhance governance, as well setting a clear timetable, and the criteria against which implementation will be assessed.

\section{A new Anti-Corruption Law has been adopted by the Parliament to support the} two institutions in their fight against corruption. The Anti-Corruption Law was prepared by an international firm under the supervision of the Anti-Corruption Commission. It was adopted by the Parliament in August 2009. The Law is penal in nature and contributes significantly to consolidating and strengthening the existing legislation on fraud and corruption. It also includes references to international best practices to ensure the conformity of the Congolese legislation to international laws and regulations on corruption.

\section{The Observatory has fulfilled its monitoring mandate so far by providing an} independent evaluation of the progress on key elements of the HIPC-related reform program. While the Observatory has a broad mandate to review any government documents related to issues of governance and corruption, it has been directed through the HIPC conditions to review and comment on documents related to procurement, governance and oil sector management. Documents reviewed by the Observatory include (i) the new procurement code and its secondary legislation, (ii) the Governance Diagnostic Study; (iii) the Governance and Anti-Corruption Action Plan and the Anti Corruption Law, including a review of implementation during the first 3 months after its adoption, (iv) the SNPC audits for 2006 and 2007, (v) the action plan on Oil Commercialization and oil commercialization procedures, and (vi) the conflict of interest declarations of SNPC's management. For each of these documents, an official opinion was issued. Going forward, the Observatory will also have responsibility for actively monitoring the application of the procurement code, as well as continuing to review the implementation of the Anti-Corruption action plan by the 
Commission, the application of the Anti-Corruption Law, and the implementation of the oil commercialization action plan by SNPC.

37. The anti-corruption action plan has been implemented satisfactorily. The staffs have verified that: the anti-corruption law is fully in force; the Anti-Corruption Observatory was indeed consulted on specified documents as noted above; and a campaign to sensitize senior government officials and the population in general on anti-corruption issues was undertaken.

\section{Oil Sector Governance}

\section{Audit of SNPC accounts}

Assessment by IDA and IMF staffs, based on successive annual audit opinions by an independent firm of international reputation, and certified by the national anti-corruption committee, that SNPC's internal controls and accounting system are in line with international standards and best practices.

38. Staffs consider this trigger as met, since annual audits have shown improvement in the quality of SNPC's internal controls evidenced by a reduction in the number and severity of reservations pointed out by the auditors. Over the past several years, SNPC has made efforts to eliminate a number of audit reservations in particular, through accurately valuing the assets received from its predecessor company (Hydro-Congo), restructuring its operations to reduce the number of subsidiaries, and the introduction of a new and modern analytical accounting system.

39. The $\mathbf{2 0 0 6}$ and in particular the $\mathbf{2 0 0 7}$ external audits showed improvement and the remaining reservations are mostly technical in nature. The audits of the consolidated accounts of SNPC for both years conducted by an internationally reputed audit firm and certified by the national anti-corruption committee have been completed and are posted on the MEFB website together with SNPC management comments. Compared with previous years, these audit reports show relative progress, but remain qualified. The qualifications relate to accounting standards and procedures, internal controls, management of bank accounts and reporting, mostly in the context of joint-venture operations between SNPC and private operations, as well as financial relations between SNPC and the central government. Also, SNPC clarified previously unsubstantiated legal fees which were paid to resolve litigation involving the government.

40. In the staffs view, the introduction of a new analytical accounting system has addressed most of the remaining audit reservations. The new financial system is now in place and has been used to prepare the 2008 financial statements. This should result in the 2008 audit — which has been launched and is expected to be completed by early 2010 reflecting significant improvement in the quality of financial statements. This improvement 
has already been confirmed in the draft audit report that has been shared with staffs. Efforts to strengthen the internal control system should continue in the period ahead.

\section{Oil commercialization}

Preparation, by an independent firm of international reputation, of a diagnostic study of the practices for the commercialization of oil by SNPC, based on terms of reference prepared in consultation with IDA and IMF staffs. Assessment by IDA and IMF staffs, based on successive audit opinions by an independent firm of international reputation, that the commercialization of oil by SNPC has been brought into line with international best practice on the basis of the recommendations of the diagnostic study, and results in competitive and fair market values to Congo for the oil sold.

\section{Staffs consider this trigger as met, since oil marketing practices and governance} have undergone major improvements since 2005. The settlement with litigating creditors holding validated claims has enabled SNPC's oil trading subsidiary, COTRADE, to return to more transparent and market-driven commercialization practices for the export of Congolese crude oil, and the timely repatriation of oil revenue to the Treasury. It has also removed the threat of legal seizures and eliminated wasteful practices and financial costs to avoid these creditors. In particular, as part of the adoption of measures in line with an action plan agreed with the staffs (see below), the authorities have eliminated the practice of requesting prepayments for cargos alone, which has significantly reduced oil marketing costs, and increased the number of its regular clients from 4 in 2005 to 14 in 2009. In addition, significant improvements were made in the transparency of oil sales: COTRADE and SNPC now transfer revenue on the basis of realized prices rather than the so-called fiscal price, which was an average of sales by international companies extracting oil in Congo. Transfers to the treasury are made within 15 days of receipts. These transfers are reconciled with budget data and certified on a quarterly basis by an international auditing firm and posted on the government's website.

\section{A diagnostic study on oil commercialization was completed in March 2007. This}

study was published on the government's website, and submitted to the IMF and IDA for comments. The government developed an action plan based on this study which initially had failed to address key issues related to commercialization practices. An international expert was recruited to advise the authorities on such matters and an action plan acceptable to the staffs was adopted in May 2009. This version of the plan was also reviewed and accepted by the Anti-Corruption Commission and Observatory as envisaged under this HIPC trigger. The action plan contains measures to be undertaken by SNPC and its subsidiary COTRADE directly, as well as administrative measures and studies that require the assistance of an oiltrading consultant firm.

43. Key actions envisaged in the action plan have been completed. In addition to the above-mentioned use of marketed oil prices for transfer to the Treasury and shortening of the timeline of transfers, these include: 
- The adoption of amendments to current oil marketing procedures, addressing three key recommendations made by an international consulting firm based on the review of COTRADE procedures (the further strengthening of the codification of marketing procedures, tightening client selection procedures, and task separation in the marketing process $)^{5}$;

- Establishment of commercialization database and adoption of measures to strengthen it as a tool for decision-making and modeling of Congolese crude oil prices;

- $\quad$ Adoption of a formal internal reporting system and a training program; and

- Integration of the COTRADE as department into the national oil company, ensuring that the significant improvements in SNPC's accounting and control systems carry over to its oil commercialization department.

\section{Staffs have undertaken a statistical analysis of price differentials to ascertain} whether Congolese oil sold by government trades at competitive and fair market prices. While the above-mentioned oil commercialization database needs to be further populated with transaction-related information, staffs — on the basis of the available data and information - are able to observe that prices received by SNPC for oil sold (Djeno and Nkossa) on behalf of the government are broadly in line with those obtained by international oil companies active in Congo (and selling oil on their own behalf). Such price data may not reflect fully competitive sales as these international oil companies could sell to their affiliates, but it does provide the closest benchmark. Staffs were able to compare SNPC's realizations with prices officially posted for Cabinda and Bonny Light, which show that SNPC's sales were broadly within or not far off the trading bandwidth of these proxies. The limitations of these proxies must be recognized, since unobserved differences in quality, traded volumes, and marketing between these proxies and Congolese oil are likely to impact their relative prices. Also the analysis shows a general improvement in the price differentials between Congolese oil and Brent since 2006, which is consistent with the trend observed for crude oil sold by international oil companies active in Congo.

\section{It should be noted that oil marketing is a dynamic process of learning based on testing different marketing channels and improving data collection on oil sales. Over} time and building on the sound and competitive procedures now in place, Congo could gain additional information to allow it to further adapt its trading techniques and strategies to changes in the international markets, which could allow it to further improve the prices it obtains for the oil sold.

\footnotetext{
${ }^{5}$ This review was based on observations by an international expert firm, the Bank and the Anti-Corruption observatory.
} 
Declaration of interests by members of the SNPC board and management

Adoption and application by the government, certified by the national Anti-Corruption Commission, during the completion of the audits referenced in 5(i) and 5(ii), of a legal text stipulating:

- compulsory declaration, to the National Auditing Office (Cour des Comptes), by the members of the Executive Board of SNPC and those having a management mandate within SNPC and its subsidiaries, at the moment of their nomination and annually thereafter, of their participation or other interests in companies having business relations with SNPC or its subsidiaries as well as the verification and annual publication of the aforementioned declarations by the National Auditing Office (Cour des Comptes).

- $\quad$ divestiture by the members of the Executive Board of SNPC and by those having management responsibilities within SNPC or any of its subsidiaries of such participations and/or other interests, within a time period of 6 months after their nomination and prohibition of the taking of any interest in companies having business relations with SNPC during the period of their mandate.

46. Staffs consider that this trigger has been met since 2006, when the government issued a decree on the prevention and resolution of conflicts of interest involving members of the Board and senior managers of SNPC (Decree No. 2006-32).

Subsequently, all board members and managers have presented declarations to the National Auditing Office (Cour des Comptes) confirming that they do not have any share or interest in any company that has relations with SNPC. The National Auditing Office has acknowledged the receipt of these declarations, and in an extension of its core functions assessed the potential for conflict of interest of all SNPC board members and senior managers. The Office reports for 2007, 2008 and 2009 have confirmed that there are no cases of conflict of interest.

Forestry sector governance

Review of forestry sector management and legislation with IDA assistance; adoption by the government of measures recommended by the review to promote competition, transparency, and sustainable development in this sector.

47. Staffs consider this trigger as met since the government has completed a comprehensive and participatory forest and environmental sector review, and began implementation of some of its major recommendations. This includes the adoption of a package of legal and regulatory instruments to improve sector transparency and social and environmental performance. More specifically, the following presidential decrees have been adopted in September 2009 and assessed satisfactory by IDA and IMF staffs:

- A decree on forest concessions, which allows for greater competition and transparency in their award; 
- A decree on social and environmental impact assessment, which provides full environmental and social assessment of projects to be implemented in forest areas;

- A decree on gazetting forest lands, which enhances this process, including through local consultations; and

- $\quad$ A decree on contradictory use of forest lands, which will help address cases where concessions or other permits have been issued for conflicting use of forest lands (i.e., cases where mining permits were awarded in national parks).

48. Measures also include the submission to Parliament of a legal package on forest taxation (passed as an amendment to the Forest Law), aimed at improving sustainability of the forest resource basis and fiscal revenue, in addition to improving the sector's economic performance. The changes to the relevant legislation include:

- A change of the basis of the export tax assessment, from free-on-board to an exworks or free-on-truck basis to take into account the transport costs and to facilitate the diversification of harvests (enlargement of the range of species to refrain from high-grading or "creaming" of the highest value species) in the concessions facing high transport costs due to their geographic location.

- An indexing of the forest concession area tax on the productive surface as set by an agreed forest management plan. Forest concessions without an agreed management plan will have to pay the tax for the full granted area.

- The transferability of log export rights ("quotas") between forest enterprises on the basis of the initial allocation of 85/15 ( 85 percent of the log production should be transformed in Congo, 15 percent can be exported as raw logs).

In addition to the above amendments, the 'surtaxe' (surcharge) for companies exporting more than the 15 percent of log export rights allocated by an administrative act, has also been removed.

49. Finally, a measure was taken to correct inconsistencies between the article regulating the surface tax in the Forestry Law (2002) and legislation of 2004 creating the Roads Fund (Fond Routier). The 2002 Forestry Law was modified to stipulate that 50 percent of the surface tax is allocated to the Roads Fund rather than local governments, as envisaged in the Forestry Law. However, it is questionable that the allocation to the Road Fund meets the need to finance decentralized development, as stipulated in the Forestry Law. While this is an issue that needs to be addressed in future discussions, it does not constitute an impediment to moving ahead with the HIPC completion point. 


\section{F. Structural Reforms}

Review and adoption of a regulatory framework for the telecommunications sector establishing competition at the level of international gateways and the wireless local loop.

50. Staffs consider the trigger related to telecom reforms as met, since the necessary legal reforms were adopted and implemented. The authorities had agreed with IDA and IMF staff on the following actions to meet the trigger: (i) the full and unambiguous repeal of Decree no 2004-466, which reserved international gateway services and the wireless local loop to be the exclusive preserve of SOTELCO, the public operator; and (ii) the complete revision of the telecommunications package and the adoption of new sectoral telecommunications/postal laws to set up an independent telecommunications regulatory authority and ensure clear and transparent regulatory regime.

\section{The first part of the trigger was met when two Presidential Decrees were} published in March 2008. These decrees, respectively (i) set conditions of management of frequency spectrum consistent with best international practice, and (ii) repealed unambiguously an earlier decree (466 of October 2004), and restored monopoly powers on international gateway.

52. The second part of the trigger was satisfactorily completed with the adoption by Parliament of a new legal framework for the postal and telecom sectors in August 2009. With the help of an international consultant, the government prepared: (i) a law instituting a regulatory agency for the sector, (ii) a law on the regulation of the electronic communications sector and, (iii) a law on the regulation of the Postal Sector. In the process, comments by IDA staff on the draft laws were incorporated.

\section{G. Social Sector Reforms}

\section{Education sector}

Implementation during 2006 of a strategy to eliminate fictitious workers from the education budget and increase teacher staff by, at least, 1,000 each year in basic education until 2007.

53. Staffs consider the triggers in this area to have been met. The first element in this area concerns increasing the number of primary school teachers. Since 2007, the authorities have recruited 1,618 primary school teacher and the recruitment of a further 2,000 is projected for this year, of which 561 had been recruited through September. The total recruitment therefore already exceeds the 2,000 teachers to be hired as per the definition of the trigger.

54. The second element concerns the elimination of ghost workers from the education budget. The census of the education sector conducted in 2006 and subsequent verification uncovered 5,163 ghost workers, equivalent to about 22 percent of total staff. Out 
of this total number, 3,717 were identified as either working at other state institutions and the remaining 1,446 unidentified staff were removed from the wage bill as envisaged. The removal of these ghost workers has created openings for new teachers, which the authorities are actively trying to recruit.

\section{HIV/AIDS}

Increase in the number of voluntary AIDS counseling and testing centers with associated measures (staff, equipment, and awareness campaigns) from 4 at present to, at least, 10 in 2006 and 15 in 2007.

55. Staffs consider this trigger as met. The trigger required that the number of voluntary testing centers should increase to 10 in 2006, and to 15 in 2007. This target has been substantially exceeded, as the number of centers providing reliable and standardized testing and counseling services has increased from two in 2004, to 59 in 2008. It is anticipated that the number of centers will increase to 99 in 2012.

\section{Health sector}

Increase to, at least, 60 percent the share of generic drugs in total expenditures on drugs by the central purchasing agency.

\section{Staffs consider this trigger as met, as the budget has included a separate} allocation for generic drugs to be purchased through the Central Drug Purchasing Authority (COMEG) since 2008. However, while the 2009 budget continues this practice, the disbursement of the budgetary allocation for the purchase of medicines through COMEG has been relatively low. The disbursement is about CFAF 747 million for the purchase of anti-retroviral drugs, compared with the budgeted allocation of CFAF 3 billion. For other drugs, there has only been a single disbursement of CFAF 500 million in mid-September 2009, compared with about CFAF 7 billion allocated to this line item in the 2009 budget. Two COMEG requests for payment (the first and second quarter 2009 titles) are currently pending at the Ministry of Finance, due to perceived problems in the inventory management system and procedures for purchases of pharmaceuticals.

\section{In this regard, the government plans to launch a general audit of the COMEG} with the objective of streamlining the budgetary resources allocated to this structure, as well as to enhance inventory management systems. This aims at preventing a repetition of the situation in 2008 , when a large quantity of drugs had to be destroyed as they were past their expiry date. Also, if disbursements are not made on time, there is a serious risk of generic medicines and anti-retroviral drugs running out of stock. From this perspective, it is imperative that the government takes immediate measures to resolve this problem until the situation can be improved on the basis of the audit recommendations. 


\section{H. Debt Management}

Publication of the quarterly external debt data and projections on a government website; and centralization of all information on debt, including collateralized debt, in the government's debt agency (CCA).

58. Staffs consider that the debt management triggers are met. Data concerning the external debt stock and debt service projections have been provided on the Ministry of Finance, Budget, and Public Portfolio's website with quarterly frequency, including the latest information through end-September 2009. This information is being produced by the Caisse Congolaise d'Amortissement (CCA), the unit in charge of managing Congo's internal and external debt, using a computerized debt management system (DEMFAS). The second part of the trigger is also complied with, as all external debt contracted by government entities, including the SNPC and other state enterprises, are now included in the debt data registered and monitored by the CCA.

59. That being said, an ambitious program is underway to further enhance debt management in Congo, and move to a more strategic approach to borrowing. Those efforts are based on a debt management diagnosis prepared with technical assistance from the World Bank and the BEAC. They also draw on a national debt strategy, which is being prepared in line with CEMAC regional guidelines. These reform efforts have two main objectives: (i) to further strengthen basic debt management functions, like collection, filing, presentation of debt data, and strengthening the internal and external control environment; and (ii) to move gradually toward a more strategic approach to debt management, which would include the issue of Treasury bills.

\section{UPDATEd DEBT RELIEF AND DEBT SUSTAINABILITY ANALYSIS}

\section{A. Data Reconciliation}

60. The debt stock at end-December 2004 has been revised downward relative to the decision point estimate. Together with the authorities, the staffs have reconciled more than 80 percent of the debt stock at end-2004 against creditor statements and other supplemental sources of information. The revised nominal debt stock at end-2004 has declined from US\$ 9.3 billion to US\$ 9.2 billion and the NPV of debt after delivery of traditional debt relief has decreased by US\$ 105 million to US\$ 5.1 billion (Table 1). Central government revenue reported at end-2004 (used to calculate the HIPC assistance at the decision point) has not been revised because there was no data revision since the decision point.

61. Part of the revisions to the end-2004 debt data reflect data discrepancies and new information presented during the debt reconciliation exercise. The main results of this exercise by type of creditors are described as follows: 
- Multilateral creditors. There were no significant revisions to the decision point database for multilateral creditors.

- $\quad$ Paris Club creditors. The NPV of debt of the Paris Club has been revised downward slightly to reflect changes in the information provided more recently for Brazil, Germany, Italy, and Spain. ${ }^{6}$ As of end-December 2004 the NPV of the Paris Club debt now stands at US\$ 4.9 billion (54.6 percent of the NPV of total external debt), compared with the decision point estimate of US\$ 5 billion. The primary Paris Club creditors at completion point would be France (33.8 percent of the NPV of total external debt) and Spain (3.8 percent of the NPV of total external debt).

- Other bilateral creditors. As of end-December 2004 the NPV of debt owed to nonParis Club creditors was US\$ 291 million (equivalent to 3 percent of the NPV of total external debt). This amount was revised upward (by US\$ 10 million in 2004 NPV terms) from the decision point estimate mainly due to changes in the principal arrears to Angola.

- Commercial creditors. As of end-December 2004 the NPV of debt owed to commercial creditors was US\$ 3.4 billion (38 percent of the NPV of total external debt), of which the London Club creditors held US $\$ 1.8$ billion. This information has been revised to reflect that some of these loans were sold to non-London Club creditors, and were not included in the 2007 London Club agreement with Congo. These loans went into litigation. The total outstanding loans held by commercial creditors remained the same, although some of the holders were changed from London Club creditors to non London Club creditors.

\section{The HIPC assistance calculated at decision point will be revised at completion} point owing to a decline in the common reduction factor. The downward revision of the end-December $2004 \mathrm{NPV}$ of debt after traditional debt relief from US\$ 5.2 billion to US $\$ 5.1$ billion results in a common reduction factor of 31.1 percent, compared with 32.4 percent committed by creditors at decision point. The recalculation of assistance is in line with existing policy rules and is above the minimum threshold (a change in the US dollar amount of HIPC relief of 1 percent of the targeted NPV of debt after HIPC relief) for adjusting the common reduction factor in response to new information. ${ }^{7}$ Consequently, the staffs recommend that debt relief under the HIPC Initiative estimated at US\$1,679 million in NPV terms at the decision point be reduced to US\$ 1,575 million (Table 2).

\footnotetext{
${ }^{6}$ At the time of the decision point, the values for some of the loans for Germany and Spain were incorrect; for Brazil and Italy, the late interest calculations have been revised.

${ }^{7}$ The targeted NPV of debt is that needed to bring the NPV of debt-to-revenue ratio to 250 percent after traditional and HIPC debt relief.
} 


\section{B. Status of Creditor Participation in the Enhanced HIPC Initiative}

63. Congo has received financing assurances of participation in the enhanced HIPC Initiative from creditors holding 80.6 percent of the NPV of HIPC assistance estimated at the decision point. Multilateral and Paris Club creditors have confirmed their participation in the HIPC Initiative while some non-Paris Club official bilateral and commercial creditors including the London Club creditors, have already signed agreements in the interim period providing their share of debt relief. The staffs have encouraged the authorities to use concerted effort toward securing the participation of the remaining creditors (Table 4).

64. Congo is expected to receive about US\$ 1.575 billion of total HIPC debt relief in end-December 2004 NPV terms at the completion point. Bilateral creditors are the largest contributors, accounting for 57 percent, followed by commercial creditors ( 36 percent) and multilateral creditors ( 7 percent).

\section{The total amount of HIPC assistance committed by Congo's multilateral} creditors at the decision point was US\$ 117.7 million in end-2004 NPV terms, which has been revised downwards to US\$ 112.9 (which represents about 7.2 percent of HIPC debt relief) (Table 4). IDA, the IMF, and the European Union provided interim HIPC assistance, amounting to US\$24.1 million in nominal terms through end-2009.

\section{Debt relief from IDA would amount to US\$ 47 million in end-2004 NPV terms,} revised downward from US\$ $\mathbf{4 9}$ million as determined at the decision point (Table 4 and Table 11). Of this amount, IDA is delivering US\$ 13.1 million in NPV terms (US\$ 14.4 million in nominal terms) via a 50 percent reduction of debt service falling due during the interim period through February 2010. Upon reaching the completion point, IDA would provide the remaining portion of its assistance, amounting to US\$33.9 million in end-2004 NPV terms through a 50 percent reduction of debt service on eligible debt through the end of 2020.

67. At the decision point, the IMF committed HIPC Initiative assistance of SDR 5.637 million (equivalent to about US\$ 8.971 million) in NPV terms. As a result of the downward revision in the total amount of HIPC assistance, there will be a marginal revision in the IMF's HIPC assistance to SDR 5.395 million (equivalent to about US\$ 8.586 million) in NPV terms at the decision point. The IMF has already provided SDR 0.9 million (equivalent to about US\$1.4 million) in the form of interim HIPC assistance in two tranches in December 2008 and December 2009. At the completion point, the IMF will provide the remaining amount of its share of HIPC assistance through a stock-of-debt operation estimated at SDR 4.5 million in NPV terms (equivalent to about SDR 5.4 million in nominal terms) (Table 10).

68. The AfDB Group committed to provide US\$ 42 million in end-2004 NPV terms in assistance at the decision point. More than the full amount of relief committed under the 
HIPC Initiative was provided via a cancellation of arrears in 2004-05, and as a consequence, the AfDB Group is not obligated to provide additional HIPC relief at the completion point. ${ }^{8}$

\section{The EU committed to providing US\$ 9.4 million in end-2004 NPV terms at the} decision point, and provided approximately US\$ 9 million in NPV terms, or about US\$ 10.6 million of relief during the interim period. Owing to the downward revision of the common reduction factor, the EU's share of HIPC relief was also revised downwards by about US\$ 0.4 million in NPV terms.

70. Other multilateral creditors have also already contributed to debt relief. The Arab Bank for Economic Development in Africa (BADEA) and the OPEC Fund for International Development (OFID) provided a proportion of their respective shares of relief via concessional restructurings and rescheduling of existing debt, and will provide the balance of their commitments at the completion point. The International Fund for Agricultural Development (IFAD) will provide debt relief only at completion point (see Table 4 for further details).

71. Paris Club Creditors have agreed in principle to provide their share of assistance under the Initiative amounting to about US\$ 3.0 billion in end-2004 NPV terms. ${ }^{9}$ Paris Club creditors are expected to deliver their share of relief through a stock-of-debt reduction under Cologne terms. The bilateral agreements implementing the December 2008 Paris Club minutes with all Paris Club creditors have been signed with the exception of Brazil, UK and Russia. Congo has a single Official Development Assistance (ODA) loan administered by IDA that has been re-scheduled with the provision that it will be cancelled on reaching completion point. ${ }^{10}$

\section{Non-Paris Club bilateral creditors are assumed to provide HIPC relief in terms} comparable to that of Paris Club creditors. The authorities have signed bilateral agreements in the interim period with Bulgaria, China, Cuba, Libya, and Romania. ${ }^{11}$ Negotiations are still ongoing with Kuwait, UAE, Saudi Arabia, Angola, and Algeria.

\footnotetext{
${ }^{8}$ Under the guidelines for the enhanced HIPC Initiative, a creditor receives credit against the required provision of debt relief for contributions to an arrears-clearance operation in a HIPC country.

${ }^{9}$ The assistance from Paris Club Creditors consists of the traditional relief of US\$ 2,177 million, and the HIPC relief of US\$ 837 million in 2004 NPV terms.

${ }^{10}$ This loan was originally a bilateral loan from a Paris Club creditor, which clarifies its qualification under the Paris Club.

${ }^{11}$ Bulgaria, Libya and Romania have canceled approximately 78-80 percent of their claims and Congo has paid off the remaining balance. China has provided 100 percent debt relief on some of its claims in the interim period. Loans from Cuba were repaid (with no relief provided).
} 
73. Congo negotiated a commercial debt restructuring agreement with London Club creditors in November 2007. The principal of total eligible debt as of November 2007 was US\$ 310 million and creditors holding 92 percent of this eligible debt participated in this agreement. This agreement included the issuance of US\$ 477 million of Eurobonds maturing in 2029, which is comparable to debt relief offered by Paris Club creditors.

\section{Some of non-London Club commercial creditors have also provided HIPC} comparable debt relief. Commercial creditors holding US\$282 million of external debt as of end-December 2004 NPV terms have provided debt relief by cancellations and rescheduling. Their participation in the HIPC Initiative was critical because this group of creditors holds approximately 20 percent of total debt in the end-2004 NPV term, which is high compared with other HIPC countries.

\section{Congo settled a long-standing dispute at the end of 2008 with litigating creditors} holding claims validated by the courts, through payments (including legal fees and court-imposed penalties) totaling US\$ 939 million (about 9 percent of GDP). ${ }^{12}$ At this point, there are three outstanding litigating creditors with claims calculated by the authorities totaling US\$ 393 million. The settlement at end-2008 was on terms significantly less favorable than those of HIPC, with a discount factor calculated at 37 percent down from an estimated 79 percent reported incorrectly by the authorities earlier. The lower discount factor was attributed to the inclusion of some debts covered by the London Club agreement as part of claims held by litigating creditors. After correcting the error, the outstanding debt was revised downward, but the total settlement to those creditors remained the same. The error on the discount factor and reconciled data was reported immediately to the staffs and the Paris Club, and the authorities have identified a number of actions to prevent such mistakes in future. These actions include restructuring of the debt unit by separating tasks for entry/recoding and verification of data, training in risk management to improve the security and control of the data, conducting regular audits of information/data to ensure accuracy, and creating a legal affairs unit.

\section{Debt Outlook after HIPC Assistance and Consideration for Exceptional Topping-Up of HIPC Assistance}

\section{Congo's nominal stock of external debt reached US\$ 5,610 million at end-} December 2008, compared with US\$ 9,248 million at end-December 2004. Multilateral creditors accounted for 8.3 percent of total debt and bilateral and commercial creditors accounted for 91.7 percent (Table 5). IDA, France, Brazil, Spain and the London Club creditors are Congo's largest creditors, accounting for 5.3 percent, 28.1 percent, 6.9 percent, 7.8 percent, and 8.1 percent, respectively, of total outstanding debt.

\footnotetext{
${ }^{12}$ Due to a confidentiality clause in the agreement, the authorities have not provided source information that would allow the staff to reconcile the related debt information and the discount factor.
} 
77. The NPV of Congo's public and publicly guaranteed external debt at endDecember 2008, after full delivery of the assistance committed under the HIPC Initiative at the decision point, is estimated at US\$ 3.5 billion, equivalent to 63 percent of fiscal revenue (excluding grants) and 48.6 percent of three-year average of exports. Of this amount, US\$253 million is owed to multilateral creditors, US\$1,890 million to Paris Club creditors, and US\$ 343 million to other bilateral creditors, and US\$ 993 million to commercial creditors (all numbers in end-2008 NPV terms).

78. The staffs are of the view that Congo does not meet the requirements for toppingup assistance under the Initiative. Topping-up could be provided only if debt ratios have deteriorated relative to the decision point projections. Congo does not qualify in this regard, since its NPV of debt-to-revenue ratio after HIPC and additional bilateral relief is far below the HIPC threshold of 250 percent. This ratio was estimated at about 38 percent in $2008 .{ }^{13}$

\section{The NPV of debt-to-revenue ratio declined in large part due to a significant} increase in oil revenue (Text Table 4). Total revenue in 2008 was US\$ 5,523 million, compared with US\$1,586 million projected at the decision point. The increase in oil revenue reflected three main factors: i) relatively high world oil prices; ii) higher than projected production, and iii) an increase in the government's share of oil output (which rises as oil prices increase, as stipulated in its production sharing contracts with private operators).

80. To summarize, the decline in the ratio of the NPV of debt-to-revenue more than offset the increase in the ratio caused by the delay in interim assistance delivery (Text Table 4). The Fund-supported program went off-track in the latter half of 2006. In response, the Paris Club stopped its interim assistance for almost two years until a new three-year PRGF arrangement was approved by the Fund's Executive Board in December 2008. Only after this date did the Paris Club reached understandings on further debt rescheduling.

\footnotetext{
${ }^{13}$ The Enhanced HIPC Initiative framework allows for the provision, on an exceptional basis, of additional debt relief (or "topping-up") at the completion point. Additional debt relief is provided if a country's actual debt burden indicators have deteriorated compared to the decision point projection, and this deterioration is primarily attributable to a fundamental change in a country's economic circumstances due to exogenous factors (The Enhanced HIPC Initiative - Completion Point Considerations). Additional debt relief may case be provided to bring a country's debt ratio to the relevant HIPC threshold at the completion point. To date, six countries have received topping-up assistance under the enhanced HIPC Initiative: Burkina Faso, Ethiopia, Rwanda, Malawi, Niger and Sao Tome and Principe.
} 
Text Table 4. Republic of Congo: Breakdown of the increase of NPV of Debt-to-Revenue Ratio, end-December $2008^{1}$

\begin{tabular}{|c|c|c|}
\hline & $\begin{array}{r}\text { Percentage } \\
\text { Points }\end{array}$ & $\begin{array}{r}\text { Percent of Total } \\
\text { Increase }\end{array}$ \\
\hline NPV of debt-to-revenue ratio (as projected at the Decision Point) & 122.9 & \\
\hline NPV of debt-to-revenue ratio (actual) & 63.0 & \\
\hline Unanticipated change in the ratio & -59.9 & 100.0 \\
\hline 1. Due to changes in the parameters & 0.5 & -0.9 \\
\hline Of which: due to changes in the discount rates & -0.1 & 0.2 \\
\hline Of which: due to changes in the exchange rates & 0.7 & -1.1 \\
\hline 2. Due to unanticipated new borrowing & 1.4 & -2.4 \\
\hline Of which: due to higher than expected disbursements & 0.1 & -0.1 \\
\hline Of which: due to lower concessionality of the loans & 1.4 & -2.3 \\
\hline 3. Due to unanticipated changes in revenue & -151.3 & 252.6 \\
\hline 4. Due to changes in HIPC relief and other factors ${ }^{2}$ & 89.4 & -149.3 \\
\hline NPV of debt-to-revenue ratio (actual) & 63.0 & \\
\hline Bilateral debt relief beyond HIPC & -24.6 & \\
\hline $\begin{array}{l}\text { NPV of debt-to-revenue ratio after full delivery of HIPC assistance and } \\
\text { bilateral debt relief beyond HIPC (actual) }\end{array}$ & 38.4 & \\
\hline Sources: Staff estimates & & \\
\hline
\end{tabular}

\section{Creditor Participation in the Multilateral Debt Relief Initiative}

\section{Contingent upon approval of the completion point, Congo would qualify for} additional debt relief under the MDRI from the AfDF, IDA, and the IMF. MDRI debt relief (net of HIPC assistance) would imply an additional cancellation of principal payments owed to participating creditors of US\$ 177.7 million in nominal terms, and would save Congo US\$201.3 million in total debt service through 2043.

82. AfDF. The AfDF would provide debt relief in addition to the HIPC Initiative already delivered, amounting to a reduction in Congo's debt stock of US\$ 9.1 million. This is equivalent to a reduction in debt service of about US\$ 9.7 million between 2010 and 2039.

83. IDA. IDA would provide debt relief in addition to the HIPC Initiative under the MDRI amounting to a reduction in principal payments of US\$ 161.2 million, by irrevocably canceling payment obligations for credits disbursed before end-2003 and still outstanding on January 1, 2010 (Table 11). MDRI debt relief from IDA would imply average debt service savings (net of HIPC assistance) of US\$ 5.4 million per year through 2043, or the equivalent of US\$ 184.0 million in total debt service.

84. IMF. The IMF would provide MDRI debt relief amounting to estimated at SDR 4.8 million (equivalent to about US\$ 7.4 million) covering the full stock of debt owed to the 
IMF at end-2004 that is still outstanding at the completion after full delivery of HIPC debt relief (Table 10). ${ }^{14}$

\section{E. Debt Sustainability Outlook, 2009-28}

85. The baseline macroeconomic framework for the debt sustainability analysis takes into account recent developments. Key macroeconomic assumptions for the completion point DSA using the HIPC methodology are summarized in Text Table 5 and Box 2. Longterm growth assumptions are broadly similar to those used in the decision point debt sustainability analysis. However, near- and medium-term growth is now assumed to be somewhat weaker, reflecting the adverse impact of the global financial crisis. Meanwhile, fiscal revenue is expected to rise to over 100 percent of non-oil GDP, which is significantly higher than the projections made at decision point, reflecting higher world oil prices and oil production. The current assumption also indicates that external borrowing will be minimal given Congo's large increased oil wealth.

Text Table 5. Republic of Congo: Long-term Macroeconomic Assumptions, 2009-29

\begin{tabular}{|c|c|c|c|c|}
\hline & $2009-13$ & 2014-18 & $2019-23$ & $2024-29$ \\
\hline & (Annual per & ge change & Otherwise & ted) \\
\hline \multicolumn{5}{|l|}{ National income and prices } \\
\hline GDP at constant prices & 6.1 & 3.0 & 4.7 & 4.9 \\
\hline Oil & 7.1 & -9.7 & -9.5 & -9.5 \\
\hline Non-oil & 5.9 & 6.9 & 6.5 & 5.7 \\
\hline Consumer prices (end-of-period) & 3.0 & 3.0 & 3.0 & 3.0 \\
\hline \multicolumn{5}{|l|}{ External sector } \\
\hline Exports of goods and services & 6.8 & -6.1 & -3.8 & -0.8 \\
\hline Oil & 7.1 & -8.4 & -8.0 & -7.6 \\
\hline Non-oil & 5.0 & 8.6 & 8.0 & 7.3 \\
\hline Imports of goods and services & 4.7 & 1.2 & 3.3 & 5.4 \\
\hline Oil & 3.7 & -8.5 & -7.8 & -7.5 \\
\hline Non-oil & 6.1 & 6.3 & 6.2 & 6.9 \\
\hline \multicolumn{5}{|l|}{ Current account balance } \\
\hline Central government & \multicolumn{4}{|c|}{ (In percent of non-oil GDP unless otherwise indicated) } \\
\hline Total revenue and grants & 130.1 & 97.7 & 60.6 & 45.4 \\
\hline Total expenditure & 63.1 & 45.9 & 36.2 & 31.5 \\
\hline Non-oil primary basice balance & -30.4 & -18.2 & -10.6 & -5.3 \\
\hline Overall balance & 67.0 & 51.8 & 24.4 & 13.9 \\
\hline \multicolumn{5}{|l|}{ National income } \\
\hline Nominal GDP (in CFAF billion) & 5.7 & 6.3 & 7.4 & 10.2 \\
\hline Oil & 3.6 & 2.9 & 1.8 & 1.1 \\
\hline Non-oil & 2.1 & 3.4 & 5.5 & 9.1 \\
\hline Nominal GDP (in US $\$$ billion) & 12.1 & 13.2 & 15.5 & 21.3 \\
\hline
\end{tabular}

Sources: Congolese authorities; and Fund estimates and projections.

${ }^{14}$ As defined in the MDRI-II Trust Instrument. 


\section{Box 2. Republic of Congo: Baseline Macroeconomic Assumptions}

Real GDP growth: Average annual overall real GDP growth for 2009-29 is projected at 4.7 percent, slightly higher than the 3.6 percent averaged for 1999-2008 owing to higher oil production. For 2009-29 economic growth is expected to be led by the non-oil sector; average real oil growth is projected to be around -5.5 percent as production is expected to diminish over time, and real non-oil growth is expected to reach 6.2 percent.

World oil price and production: Oil production is expected to peak in 2011 at 137 million barrels per year and then gradually decline to 24 million barrels per year in 2029. The Congolese oil export price is projected to increase slightly more than international oil prices in the long term, owing to oil marketing reform.

Inflation: Inflation is projected to decline to 3.2 percent by the end of 2009 and hold at 3 percent thereafter, reflecting BEAC's objective of low inflation. This is in line with the Central African Economic and Monetary Community (CEMAC) convergence criterion of 3 percent.

Current account balance: The current account balance is expected to turn to a surplus of 1.8 percent of GDP in 2010, rising to around 5 percent for 2011-2016, but may swing into deficit in 2017 because of declining oil production. By 2029, the deficit is expected to reach over 15 percent of GDP, which will be financed by foreign direct investment (FDI) and from oil revenue savings deposited in the oil stabilization account at the BEAC. FDI in the non-oil sector is projected to grow by around 10 percent annually as Congo bolsters the investment environment. The share of the non-oil sector in FDI is projected to increase to over 80 percent in 2029 from about 10 percent in 2009.

Government balance: The government is expected to continue with its fiscal consolidation efforts, with the goal of ensuring steady progress toward long-term sustainability consistent with a permanent income hypothesis model. The non-oil primary basic balance is expected to reach the sustainable level of 4-6 percent of non-oil GDP by 2026. The overall fiscal balance is projected to continue to record a surplus, but it will decline to about 10 percent of non-oil GDP in 2029, from 70-90 percent in 2010-2012 - again a result of the projected decline in oil production.

External assistance: Grants, mainly in the form of technical assistance, are assumed to remain at around 1 percent of GDP annually through 2029. New loans are expected from the French Development Agency (AFD), Arab Bank for Economic and Development in Africa (BADEA), IDA, and China. From 2019, Congo is expected to obtain limited amounts of non-concessional loans from the IBRD.

Domestic borrowing: No new domestic borrowing is assumed for the entire projection period given Congo's abundant oil wealth. It is assumed that domestic arrears will be fully repaid by 2014 .

86. After reaching the decision point in March 2006, the authorities negotiated debt relief agreements with major creditor groups. Paris Club creditors provided flow relief on the basis of Cologne terms. The authorities also negotiated a commercial debt restructuring agreement with the London Club which was finalized in November 2007. Several non-Paris Club creditors and commercial creditors settled their claims with Congo with HIPC comparable terms in the interim period. The Congolese have also eliminated a large portion of their commercial debt under litigation at the end of 2008, which corresponds to about 5 percent of total debt outstanding in the 2004 NPV terms.

87. Thanks to these efforts, after the full delivery of relief under the enhanced HIPC Initiative, the NPV of debt-to-revenue ratio (including new borrowing) is estimated to fall from 250 percent at end-2004 to 66 percent in 2010 (Figure 2 and Table 8). The staffs' projections indicate that-assuming continued modest real income growth and total 
revenue - the ratio would remain well below the HIPC threshold of 250 percent over the entire projection period, reaching about 15 percent by 2029 .

88. External debt service as a ratio of revenue after the full delivery of HIPC debt relief is expected to remain below 10 percent over the projection period (Figure 2 and Table 8). This ratio in 2010 is estimated at 5 percent and projected to decline gradually in the long term.

89. Full delivery of HIPC and MDRI debt relief at the completion point would significantly reduce Congo's external public debt. In end-December 2008 NPV terms, the stock of debt would decline to US\$ 3.7 billion at end-2010 (Table 6). Nominal debt service relief over the projected period would amount to US\$ 4.6 billion, of which US\$ 201 million would be related to the MDRI (Table 7).

\section{F. Sensitivity Analysis}

90. Two alternative scenarios were carried out to simulate the trajectory of Congo's external debt burden indicators after assuming full delivery of enhanced HIPC assistance, additional bilateral assistance, and debt relief under the MDRI (Figure 3 and Table 9). These scenarios replicate those used at decision point to illustrate the vulnerability of Congo's debt dynamics to various types of exogenous shocks.

\section{Alternative Scenario 1: Lower oil price}

91. This scenario assumes that the Congolese oil price is lower than the baseline scenario by 25 percent. Lower Congolese oil prices may materialize if the international oil market deteriorates and/or reforms on oil commercialization fail to reduce the differential between international prices and Congolese prices. Lower oil prices would result in lower fiscal revenue and lower exports (in value terms). In order to achieve the long-term sustainability in line with the permanent income model, the government would need to reduce public investment to some extent, which could cause weaker non-oil growth. The ratio of the NPV of external debt-to-revenue rises; over the period 2009-29 the ratio is on average higher by about 8 percentage points per year relative to the baseline scenario.

\section{Alternative Scenario 2: Lower non-oil economic growth}

92. This scenario assumes that non-oil economic growth is lower than the baseline scenario by 2 percentage points. Lower non-oil growth may result from an adverse external environment, slow implementation of structural reforms and consequently further erosion in the business environment, which would hamper private sector development. Lower non-oil growth would have an adverse impact on non-oil fiscal revenues and non-oil exports. The government would need to reduce expenditures, including public investment in infrastructure in order to safeguard fiscal resources, which itself could result in a further weakening of nonoil growth. The impact of this shock, while not as pronounced over the medium term as the oil price effect, would increase over time as the share of the non-oil sector increases. The 
NPV of external debt-to-revenue over the period 2009-29 is higher by about 1.5 percentage points per year relative to the baseline scenario. Under both scenarios, the NPV of debt-to revenue ratio remains below the 250-percent threshold over the simulation period.

\section{The sensitivity analysis indicates that Congo is moderately vulnerable to shocks} after the substantial debt relief it is expected to receive at the completion point. ${ }^{15}$ Debt indicators deteriorate under alternative scenarios compared to the baseline scenario, but stay below the HIPC threshold of 250 percent of fiscal revenue for the entire projected period. The debt relief expected at the completion point would strengthen the resilience of the country's debt indicators to shocks. It is still important that the government continues to strengthen debt management and maintain a conservative borrowing policy. At the same time, the government's commitment to maintain fiscal discipline and increase non-oil revenue, together with structural reform in key areas, would help to safeguard long-term debt sustainability.

\section{Conclusion}

\section{In the view of the staffs of IDA and IMF, Congo has met the requirements} established in March 2006 for reaching the completion point under the enhanced HIPC initiative. Staffs of IDA and the IMF consider that Congo's performance in implementing the conditions specified for reaching the completion point has been satisfactory. It has introduced the required measures to meet the objectives laid out under the eight triggers, and moved decisively to implement reforms in public investment management, procurement, governance and oil sector management as envisaged. The main elements of the HIPC reform program have been satisfactorily implemented.

\section{Revisions to the end-2004 debt data have resulted in a downward adjustment in} the amount of HIPC debt relief. Consequently, the common reduction factor has declined from 32.4 percent to 31.1 percent. The amount of HIPC debt relief required to reduce the NPV of debt-to-revenue ratio to 250 percent on the basis of end-December 2004 data has been lowered from US\$1,679 million estimated at the decision point to US\$1,575 million. Financing assurances have been received regarding participation in the enhanced HIPC Initiative from creditors representing more than 80 percent of the NPV of debt at end-2004, after traditional debt relief mechanisms have been applied.

\section{Full delivery of HIPC debt relief, and additional bilateral assistance beyond} HIPC and MDRI, would considerably reduce Congo's external public debt. In end-2008 NPV terms, the stock of debt would decline to US\$2,014 million at the completion point.

\footnotetext{
${ }^{15}$ This result is different from that in LIC DSA because of different borrowing assumption. Please see Appendix II LIC DSA for detailed explanation.
} 
97. In light of the above, the staffs of IDA and IMF recommend that the Executive Directors determine that Congo has reached the completion point under the enhanced HIPC Initiative.

\section{ISSUES FOR DISCUSSION}

98. Executive Directors may wish to consider this report based on the following issues for discussion:

- Completion point. Do Directors agree that Congo has reached the completion point under the enhanced HIPC Initiative, considering the emphasis in the decision point document on the need to establish a track record of sustained performance?

- Data Revision. Do Directors agree with staffs' recommendation that the revenue data and the updated stock of debt in end-2004 NPV terms warrant a revision in the proposed amount of HIPC assistance?

- Creditor Participation. Do Directors agree that Congo's creditors have given sufficient assurances to irrevocably commit HIPC Initiative assistance to the Congo?

- $\quad$ HIPC assistance from the IMF. Do IMF Directors agree with the downward revision in IMF HIPC assistance from SDR 5.637 million to SDR 5.395 million?

- $\quad$ MDRI/HIPC debt relief. Do IMF Directors agree that Congo qualifies for debt relief from the IMF equal to about SDR 10.9 million, of which an estimated SDR 4.8 million would be financed from the MDRI-II Trust, and the rest from Congo's HIPC Umbrella sub-account? 
Figure 1. Republic of Congo: Composition of the Stock of External Debt by Creditor Group, end-November 2004 and 2008 (in percent)

\section{End December-2004}

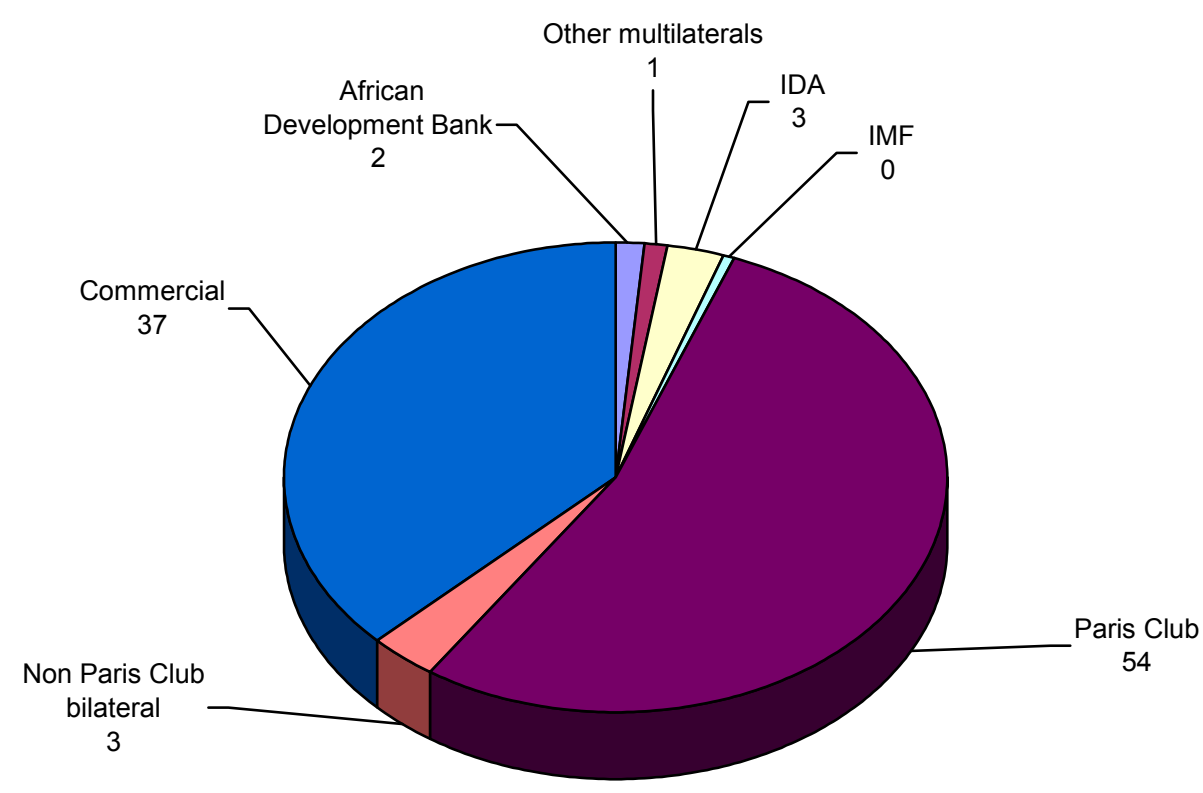

\section{End December-2008}

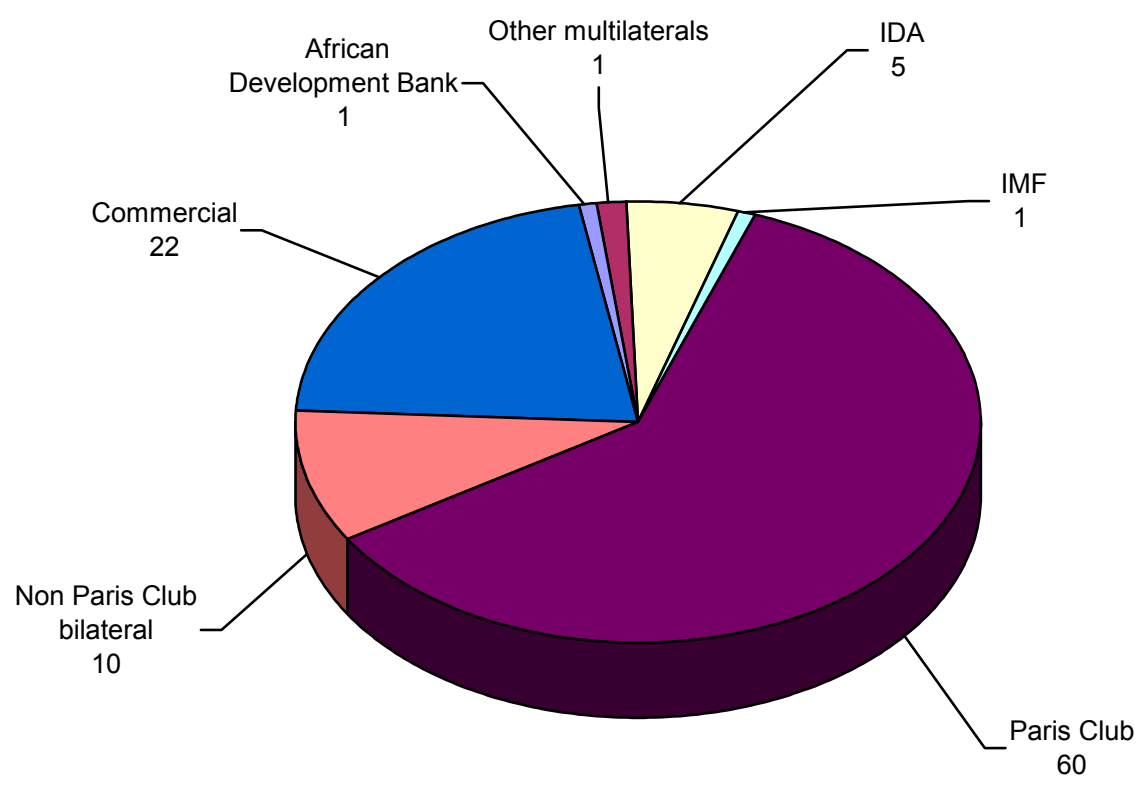

Sources: Congolese authorities; and World Bank and Fund staff estimates. 
Figure 2. Republic of Congo: External Debt and Debt Service Indicators for Medium- and Long-Term Public Sector Debt, 2009-28

Net Present Value of External Debt-to-Revenue (in percent)



Debt Service-to-Revenue (in percent)

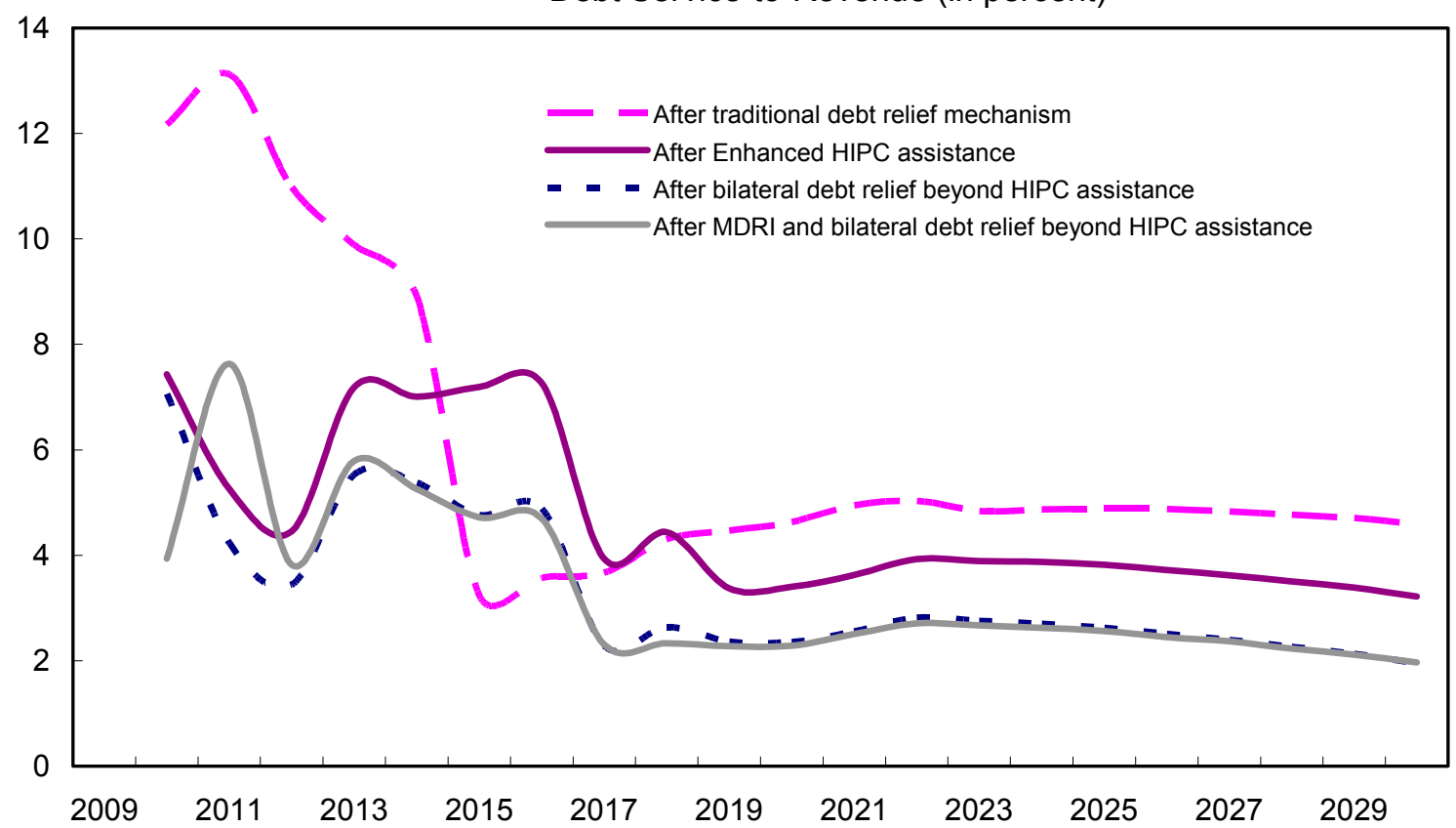

Sources: Congolese authorities; and World Bank and Fund staff estimates. 
Figure 3. Republic of Congo: Sensitivity Analysis, 2009-28

Net Present Value of External Debt-to-Revenue (in percent)

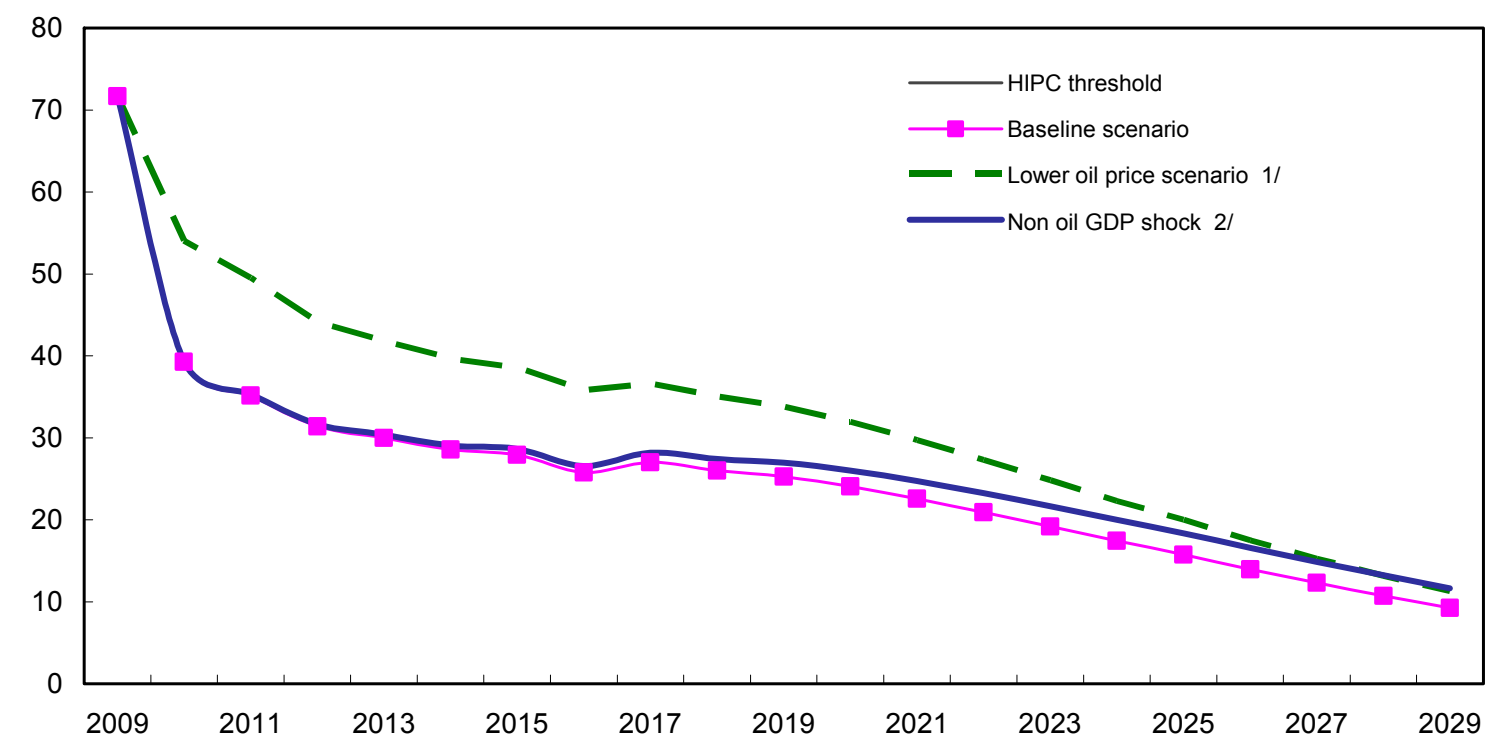

Debt Service-to-Revenue (in percent)

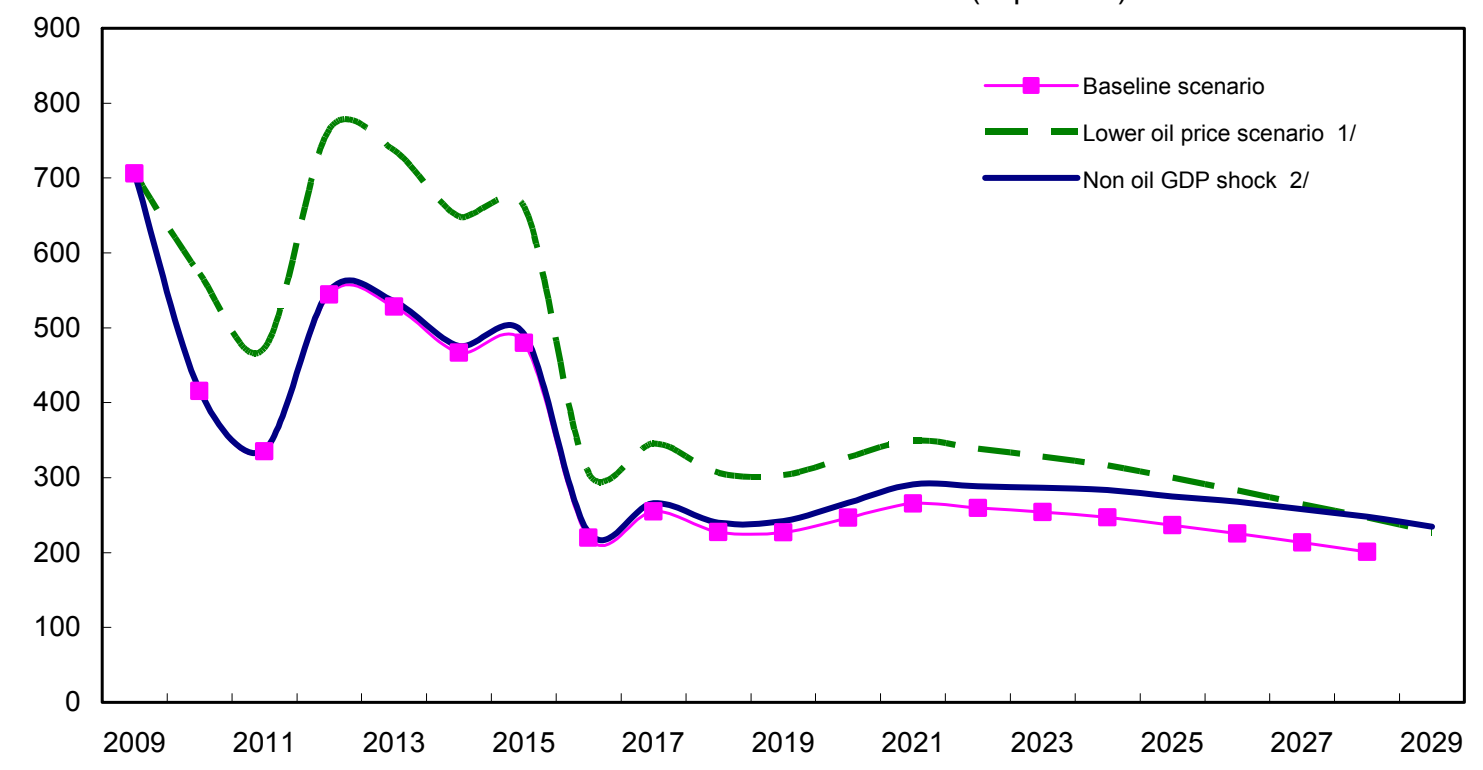

Sources: Congolese authorities; and staff estimates.

${ }^{1} 25$ percent lower than baseline scenario.

${ }^{2} 2$ percentage points lower than baseline scenario. 
Table 1. Republic of Congo: Revised Nominal Stocks and Net Present Value of Debt at Decision Point by Creditor Groups as of end-December $2004^{1}$

\begin{tabular}{|c|c|c|c|c|c|c|c|c|c|c|c|c|}
\hline & \multicolumn{4}{|c|}{$\begin{array}{c}\text { Nominal Debt Stock } \\
\text { at End-December, } 2004\end{array}$} & \multicolumn{4}{|c|}{ NPV of Debt Before Rescheduling ${ }^{2}$} & \multicolumn{4}{|c|}{ NPV of Debt After Rescheduling ${ }^{2,3}$} \\
\hline & \multicolumn{2}{|c|}{ At Decision Point } & \multicolumn{2}{|c|}{$\begin{array}{c}\text { Revised At } \\
\text { Completion Point }\end{array}$} & \multicolumn{2}{|c|}{ At Decision Point } & \multicolumn{2}{|c|}{$\begin{array}{c}\text { Revised At } \\
\text { Completion Point }\end{array}$} & \multicolumn{2}{|c|}{ At Decision Point } & \multicolumn{2}{|c|}{$\begin{array}{c}\text { Revised At } \\
\text { Completion Point }\end{array}$} \\
\hline & $\begin{array}{c}\text { US\$ } \\
\text { million }\end{array}$ & $\begin{array}{l}\text { Percent } \\
\text { of total }\end{array}$ & $\begin{array}{c}\text { US\$ } \\
\text { million }\end{array}$ & $\begin{array}{l}\text { Percent } \\
\text { of total }\end{array}$ & $\begin{array}{l}\text { US\$ } \\
\text { million }\end{array}$ & $\begin{array}{l}\text { Percent } \\
\text { of total }\end{array}$ & $\begin{array}{c}\text { US\$ } \\
\text { million }\end{array}$ & $\begin{array}{l}\text { Percent } \\
\text { of total }\end{array}$ & $\begin{array}{c}\text { US\$ } \\
\text { million }\end{array}$ & $\begin{array}{l}\text { Percent } \\
\text { of total }\end{array}$ & $\begin{array}{c}\text { US\$ } \\
\text { million }\end{array}$ & $\begin{array}{l}\text { Percent } \\
\text { of total }\end{array}$ \\
\hline Total & $9,248.3$ & 100 & 9,177 & 100 & 9,007 & 100 & 8,925 & 100 & 5,176 & 100 & 5,071 & 100 \\
\hline Multilateral & 524 & 6 & 524 & 6 & 363 & 4 & 363 & 4 & 363 & 7 & 363 & 7 \\
\hline African Development Bank & 138 & 1 & 138 & 2 & 121 & 1 & 121 & 1 & 121 & 2 & 121 & 2 \\
\hline African Development Fund & 12 & 0 & 12 & 0 & 8 & 0 & 8 & 0 & 8 & 0 & 8 & 0 \\
\hline BADEA & 21 & 0 & 21 & 0 & 16 & 0 & 16 & 0 & 16 & 0 & 16 & 0 \\
\hline European Union & 40 & 0 & 40 & 0 & 29 & 0 & 29 & 0 & 29 & 1 & 29 & 1 \\
\hline IFAD & 0 & 0 & 0 & 0 & 0 & 0 & 0 & 0 & 0 & 0 & 0 & 0 \\
\hline IDA & 270 & 3 & 271 & 3 & 151 & 2 & 152 & 2 & 151 & 3 & 152 & 3 \\
\hline IMF & 29 & 0 & 29 & 0 & 25 & 0 & 25 & 0 & 25 & 0 & 25 & 0 \\
\hline Official bilateral and commercial & 8,725 & 94 & 8,652 & 94 & 8,645 & 96 & 8,561 & 96 & 4,813 & 93 & 4,708 & 93 \\
\hline Paris Club & 5,048 & 55 & 4,936 & 54 & 4,994 & 55 & 4,872 & 55 & 2,815 & 54 & 2,696 & 53 \\
\hline Belgium & 81 & 1 & 81 & 1 & 85 & 1 & 84 & 1 & 36 & 1 & 36 & 1 \\
\hline Brazil & 309 & 3 & 315 & 3 & 291 & 3 & 287 & 3 & 102 & 2 & 104 & 2 \\
\hline Canada & 69 & 1 & 68 & 1 & 68 & 1 & 67 & 1 & 37 & 1 & 37 & 1 \\
\hline Denmark & 2 & 0 & 2 & 0 & 1 & 0 & 1 & 0 & 0 & 0 & 0 & 0 \\
\hline France & 2,942 & 32 & 2,956 & 32 & 3,002 & 33 & 3,016 & 34 & 1,729 & 33 & 1,731 & 34 \\
\hline Germany & 301 & 3 & 282 & 3 & 308 & 3 & 289 & 3 & 138 & 3 & 134 & 3 \\
\hline Ireland & 0 & 0 & 0 & 0 & 0 & 0 & 0 & 0 & 0 & 0 & 0 & 0 \\
\hline Italy & 255 & 3 & 270 & 3 & 256 & 3 & 270 & 3 & 142 & 3 & 151 & 3 \\
\hline Netherlands & 0 & 0 & 0 & 0 & 0 & 0 & 0 & 0 & 0 & 0 & 0 & 0 \\
\hline Russia & 159 & 2 & 159 & 2 & 104 & 1 & 104 & 1 & 104 & 2 & 104 & 2 \\
\hline Spain & 494 & 5 & 364 & 4 & 464 & 5 & 335 & 4 & 315 & 6 & 187 & 4 \\
\hline Switzerland & 25 & 0 & 25 & 0 & 24 & 0 & 24 & 0 & 9 & 0 & 9 & 0 \\
\hline United Kingdom & 346 & 4 & 348 & 4 & 332 & 4 & 335 & 4 & 164 & 3 & 165 & 3 \\
\hline United States & 65 & 1 & 66 & 1 & 59 & 1 & 59 & 1 & 38 & 1 & 38 & 1 \\
\hline Angola & 60 & 1 & 71 & 1 & 60 & 1 & 71 & 1 & 20 & 0 & 23 & 0 \\
\hline Bulgaria & 2 & 0 & 1 & 0 & 2 & 0 & 1 & 0 & 1 & 0 & 0 & 0 \\
\hline China & 47 & 1 & 50 & 1 & 39 & 0 & 40 & 0 & 34 & 1 & 35 & 1 \\
\hline Cuba & 1 & 0 & 1 & 0 & 1 & 0 & 1 & 0 & 1 & 0 & 1 & 0 \\
\hline Saudi Arabia & 64 & 1 & 63 & 1 & 64 & 1 & 63 & 1 & 51 & 1 & 47 & 1 \\
\hline Kuwait & 49 & 1 & 49 & 1 & 49 & 1 & 49 & 1 & 41 & 1 & 41 & 1 \\
\hline Libya & 28 & 0 & 28 & 0 & 28 & 0 & 28 & 0 & 9 & 0 & 9 & 0 \\
\hline Luxembourg $^{4}$ & 1 & 0 & 1 & 0 & 1 & 0 & 1 & 0 & 0 & 0 & 0 & 0 \\
\hline Romania & 1 & 0 & 1 & 0 & 1 & 0 & 1 & 0 & 1 & 0 & 1 & 0 \\
\hline United Arab Emirates & 17 & 0 & 17 & 0 & 17 & 0 & 17 & 0 & 15 & 0 & 15 & 0 \\
\hline Commercial & 3,388 & 37 & 3,416 & 37 & 3,370 & 37 & 3,398 & 38 & 1,819 & 35 & 1,832 & 36 \\
\hline of which: London Club ${ }^{5}$ & 2,177 & 24 & 1,825 & 20 & 2,177 & 24 & 1,825 & 20 & 879 & 17 & 721 & 14 \\
\hline
\end{tabular}

Sources: Congolese authorities; and World Bank and Fund staff estimates.

${ }^{1}$ Information based on end-December 2004 data available at completion point before signing bilateral agreements referred to in the December 2004 Paris Club agreement.

${ }^{2}$ Includes a stock-of-debt operation on Naples terms at end-December 2004; and comparable action by other official bilateral creditors on eligible debt (precutoff and non-ODA).

${ }^{3}$ The increase in the NPV of debt for the official bilateral creditors depends on the better documentation available at completion point.

${ }^{4}$ Claims from Luxembourg are a part of the European Union loan that is administered by IDA.

${ }^{5}$ Revised to indicate the claims of the creditors who have participated in the 2007 London Club agreement. 
Table 2. Republic of Congo: Estimated Assistance at Decision Point (Amended) ${ }^{1}$

(In millions of U.S. dollars in end-December 2004 NPV terms, unless otherwise indicated) ${ }^{2}$

\begin{tabular}{|c|c|c|c|c|c|}
\hline & Total & Multilaterals & Bilaterals & Commercial & $\begin{array}{r}\text { Common } \\
\text { Reduction } \\
\text { Factor }^{3} \\
\text { (Percent) }\end{array}$ \\
\hline NPV of debt-to-exports target (in percent) & 250 & & & & \\
\hline Assistance (decision point document) & 1,679 & 118 & 971 & 590 & 32.45 \\
\hline Assistance (revised) & 1,575 & 113 & 893 & 569 & 31.05 \\
\hline \multicolumn{6}{|l|}{ Memorandum items: } \\
\hline Revised NPV of debt at end-2004 ${ }^{4}$ & 5,071 & 363 & 2,875 & 1,832 & \\
\hline Central government revenues at end-2004 ${ }^{5}$ & 1,399 & & & & \\
\hline Revised NPV of debt-to-revenue ratio (percent) ${ }^{6}$ & 363 & & & & \\
\hline
\end{tabular}

Sources: Congolese authorities; and World Bank and Fund staff estimates and projections.

${ }^{1}$ Assumes proportional burden-sharing after full application of traditional debt relief mechanisms.

2 Using six-month backward-looking discount rates at end-December 2004 and end-December 2004 exchange rates.

${ }^{3}$ Each creditor's NPV reduction in percent of its exposure at the decision point (after hypothetical Naples stock at the end of the base year).

${ }^{4}$ Includes traditional debt relief; a hypothetical stock-of-debt on Naples terms with comparable treatment from non Paris Club creditors.

${ }^{5}$ Based on the latest annual data at the completion point on the end of period 2004 fiscal revenue excluding grants.

${ }^{6}$ After a hypothetical stock-of-debt operation on Naples terms at end December-2004. 
Table 3. Republic of Congo: Comparison of Discount Rate and Exchange Rate Assumptions

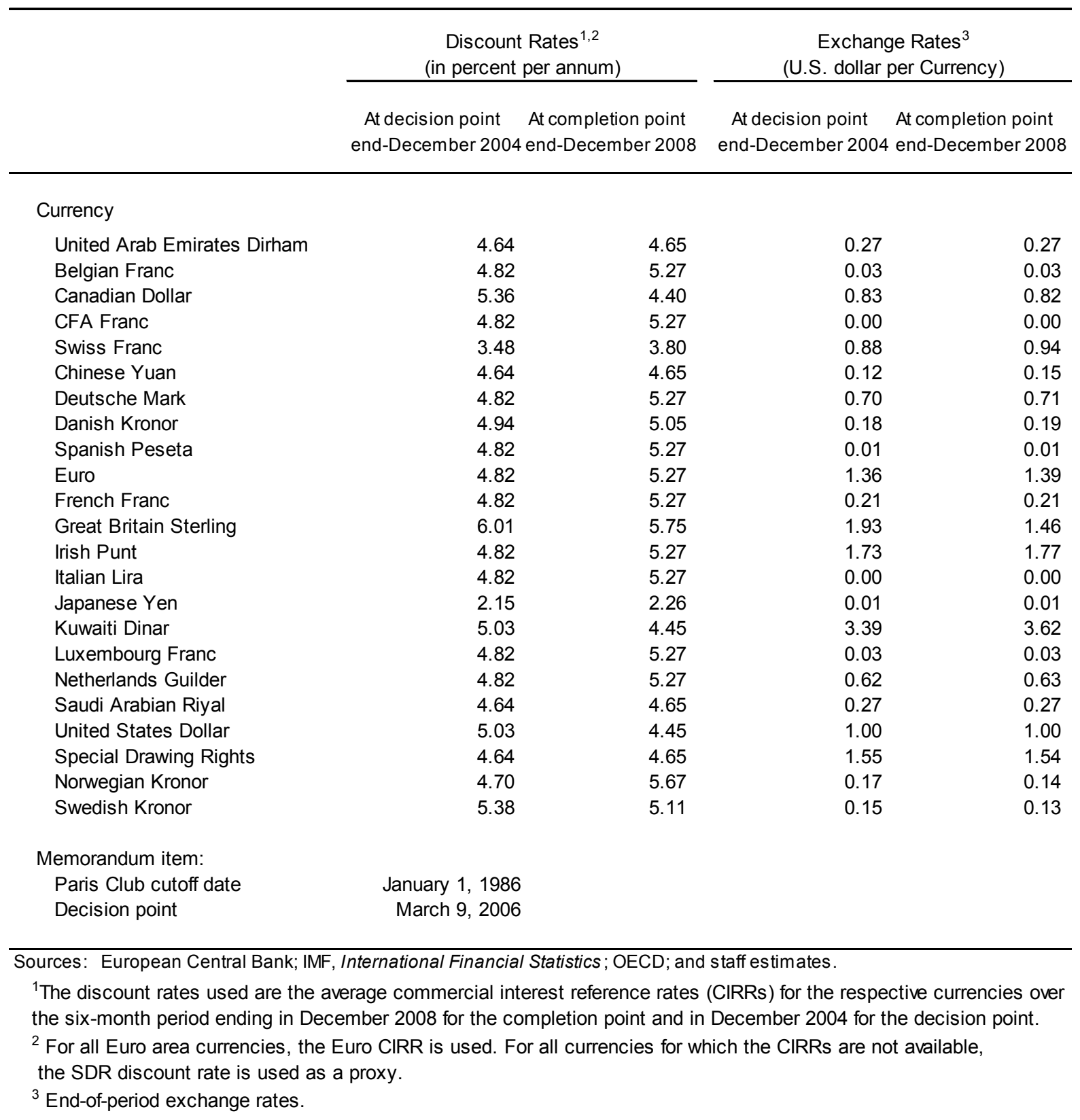


Table 4. Republic of Congo: Status of Creditor Participation Under the Enhanced HIPC Initiative

\begin{tabular}{|c|c|c|c|c|c|}
\hline & $\begin{array}{l}\text { Debt Relief } \\
\text { in NPV } \\
\text { Terms } \\
\text { (US\$ mil.) }\end{array}$ & $\begin{array}{l}\text { Percentage } \\
\text { of Total } \\
\text { Assistance }\end{array}$ & $\begin{array}{l}\text { Satisfactory } \\
\text { Reply to } \\
\text { Participate } \\
\text { in Initiative }\end{array}$ & $\begin{array}{l}\text { Percentage } \\
\text { of Total } \\
\text { Assistance } \\
\text { Participating } \\
\text { the Initiative }\end{array}$ & Modalities to Deliver Debt Relief \\
\hline African Development Bank & 37.6 & 2.4 & yes & 2.4 & $\begin{array}{l}\text { The AfDB Group's total debt relief under the HIPC Initiative } \\
\text { was estimated at } \$ 41.9 \text { million in end- } 2004 \text { NPV terms at the } \\
\text { decision point. This was more than covered by the } 2004-05 \\
\text { arrears clearance agreement. }^{1}\end{array}$ \\
\hline African Development Fund & 2.4 & 0.2 & yes & 0.2 & See above. \\
\hline BADEA & 5.0 & 0.3 & yes & 0.3 & $\begin{array}{l}\text { BADEA provided HIPC relief via the concessional element of } \\
\text { an arrears restructuring agreement in } 2001 \text {, which was } \\
\text { further revised in } 2003 \text {, leaving about } \$ 2.4 \text { million in end- } \\
2004 \text { NPV terms to be delivered at the completion point. }\end{array}$ \\
\hline European Union & 9.0 & 0.6 & yes & 0.6 & $\begin{array}{l}\text { The EU's share of debt relief under the HIPC Initiative was } \\
\text { estimated at } \$ 9.4 \text { million in end- } 2004 \text { NPV terms at the } \\
\text { decision point, which was revised downward to } \$ 9.0 \text { million } \\
\text { at the completion point owing to revisions of the debt stock } \\
\text { and the common reduction factor. }\end{array}$ \\
\hline IFAD & 0.1 & 0.0 & yes & 0.0 & $\begin{array}{l}\text { The IFAD's share of HIPC relief amounts to } \$ 91 \text { thousand in } \\
\text { end-2004 NPV terms, to be delivered at the completion point. }\end{array}$ \\
\hline IDA & 47.0 & 3.0 & yes & 3.0 & $\begin{array}{l}\text { IDA's remaining share of HIPC relief amounts to } \$ 33.9 \\
\text { million in end-2004 NPV terms to be delivered at the } \\
\text { completion point. }\end{array}$ \\
\hline IMF & 7.7 & 0.5 & yes & 0.5 & $\begin{array}{l}\text { The IMF's remaining share of HIPC relief amounts to US } \$ 9.6 \\
\text { million to be delivered at the completion point. }\end{array}$ \\
\hline OFID & 3.9 & 0.2 & yes & 0.2 & $\begin{array}{l}\text { The OPEC Fund for International Development provided } \\
\text { HIPC relief via a concessional arrears restructuring, leaving } \\
\text { about US } \$ 4.1 \text { million to be delivered at the completion point. }\end{array}$ \\
\hline Total multilateral & 112.9 & 7.2 & yes & 7.2 & \\
\hline Paris Club creditors & 837.0 & 53.2 & yes & 53.2 & $\begin{array}{l}\text { Paris Club creditors will provide relief based on Cologne } \\
\text { terms. The UK, Brazil and Russia are yet to sign bilateral } \\
\text { agreements. }\end{array}$ \\
\hline Non-Paris Club creditors ${ }^{2}$ & 55.8 & 3.5 & & 0.6 & \\
\hline Algeria & 2.0 & 0.1 & no & - & No agreement has been signed. \\
\hline Angola & 7.3 & 0.5 & no & - & No agreement has been signed. Negotiations are ongoing. \\
\hline Bulgaria & 0.1 & 0.0 & yes & 0.0 & $\begin{array}{l}\text { Signed an agreement in June } 2008 \text { that cancelled } 77 \% \text { of the } \\
\text { claims. Congo has paid the remaining. }\end{array}$ \\
\hline China & 11.0 & 0.7 & yes & 0.4 & $\begin{array}{l}\text { China has provided } 100 \% \text { cancellations only on some of its } \\
\text { claims in the interim period. }\end{array}$ \\
\hline Cuba & 0.4 & 0.0 & no & - & All loans with Cuba have been repaid. \\
\hline Saudi Arabia & 14.6 & 0.9 & no & - & No agreement has been signed. Negotiations are ongoing. \\
\hline Kuwait & 12.7 & 0.8 & no & - & No agreement has been signed. Negotiations are ongoing. \\
\hline Libya & 2.9 & 0.2 & yes & 0.2 & $\begin{array}{l}\text { Signed an agreement in April } 2008 \text { that cancelled } 80 \% \text { of the } \\
\text { claims. Congo has paid the remaining. }\end{array}$ \\
\hline Romania & 0.2 & 0.0 & yes & 0.0 & $\begin{array}{l}\text { Signed an agreement in June } 2008 \text { that cancelled } 77.7 \% \text { of } \\
\text { the claims. Congo has paid the remaining. }\end{array}$ \\
\hline United Arab Emirates & 4.6 & 0.3 & no & - & No agreement has been signed. Negotiations are ongoing. \\
\hline Total bilateral & 892.8 & 56.7 & & & \\
\hline Total commercial & 568.9 & 36.1 & & 19.7 & \\
\hline of which: London Club & 223.8 & 14.2 & yes & 14.2 & $\begin{array}{l}\text { Signed an agreement in November } 2007 \text { which lead to the } \\
\text { issuance of Euro bonds worth } \$ 477 \text { million to be paid over } \\
22 \text { years. }\end{array}$ \\
\hline of which: non-London Club ${ }^{3}$ & 345.2 & 21.9 & no & 5.5 & $\begin{array}{l}\text { A few commercial creditors have provided debt relief in terms } \\
\text { of cancellations and reschedulings that are HIPC }\end{array}$ \\
\hline Total & 1574.6 & 100.0 & & 80.6 & \\
\hline
\end{tabular}

Sources: Congolese authorities, and World Bank and Fund staff estimates.

${ }^{1}$ Under the HIPC Initiative guidelines, a creditor receives credit against the required provision of debt relief for contributions to an arrears clearance operation in a HIPC country.

${ }^{2}$ Non-Paris Club creditors holding $0.59 \%$ of the NPV of external debt after traditional debt relief have provided HIPC relief.

${ }^{3}$ Non-London Club creditors holding $5.49 \%$ of the NPV of external debt after traditional debt relief have provided HIPC relief. 
Table 5. Republic of Congo: Nominal and Net Present Value of External Debt Outstanding at End-December $2008^{1}$ (In millions of US\$, unless otherwise indicated)

\begin{tabular}{|c|c|c|c|c|c|c|c|}
\hline & \multicolumn{4}{|c|}{ Legal Situation $^{2}$} & \multicolumn{3}{|c|}{ Net Present Value of Debt ${ }^{3}$} \\
\hline & $\begin{array}{l}\text { Nominal } \\
\text { Debt }\end{array}$ & $\begin{array}{l}\text { Percent } \\
\text { of total }\end{array}$ & $\begin{array}{l}\text { NPV of } \\
\text { debt }\end{array}$ & $\begin{array}{l}\text { Percent } \\
\text { of total }\end{array}$ & $\begin{array}{c}\text { After } \\
\text { enhanced } \\
\text { HIPC relief }\end{array}$ & $\begin{array}{c}\text { After additional } \\
\text { bilateral relief }\end{array}$ & $\begin{array}{l}\text { After additional } \\
\text { bilateral relief }\end{array}$ \\
\hline & & & & & & & $\begin{array}{l}\text { (in percent of } \\
\text { total debt) }\end{array}$ \\
\hline Total & $5,610.3$ & 100.0 & $5,051.3$ & 100.0 & $3,479.0$ & $2,118.5$ & 100.0 \\
\hline Multilateral institutions & 465.3 & 8.3 & 313.9 & 6.2 & 253.3 & 253.3 & 12.0 \\
\hline African Development Bank & 50.7 & 0.9 & 53.2 & 1.1 & 53.2 & 53.2 & 2.5 \\
\hline African Development Fund & 21.5 & 0.4 & 10.8 & 0.2 & 10.8 & 10.8 & 0.5 \\
\hline BADEA & 12.3 & 0.2 & 10.8 & 0.2 & 7.9 & 7.9 & 0.4 \\
\hline European Union & 30.7 & 0.5 & 22.1 & 0.4 & 20.2 & 20.2 & 1.0 \\
\hline IFAD & 8.0 & 0.1 & 4.0 & 0.1 & 3.9 & 3.9 & 0.2 \\
\hline IDA & 296.4 & 5.3 & 174.5 & 3.5 & 132.2 & 132.2 & 6.2 \\
\hline IMF & 38.2 & 0.7 & 31.0 & 0.6 & 22.8 & 22.8 & 1.1 \\
\hline OFID & 7.4 & 0.1 & 7.4 & 0.1 & 2.3 & 2.3 & 0.1 \\
\hline Official bilateral and commercial & 5145.0 & 91.7 & 4737.5 & 93.8 & 3225.7 & 1865.2 & 50.5 \\
\hline Paris Club ${ }^{4}$ & 3395.4 & 60.5 & 3148.8 & 62.3 & 1889.9 & 737.0 & 34.8 \\
\hline Post-cutoff date & 261.5 & 4.7 & 255.8 & 5.1 & $\ldots$ & $\ldots$ & $\ldots$ \\
\hline Pre-cutoff date & 3133.8 & 55.9 & 2893.0 & 57.3 & $\ldots$ & $\ldots$ & $\ldots$ \\
\hline ODA & 339.3 & 6.0 & 239.5 & 4.7 & $\ldots$ & $\ldots$ & $\ldots$ \\
\hline Non-ODA & 2794.5 & 49.8 & 2653.5 & 52.5 & $\ldots$ & $\ldots$ & $\ldots$ \\
\hline \multicolumn{8}{|l|}{ by country: } \\
\hline Belgium & 75.9 & 1.4 & 62.6 & 1.2 & $\ldots$ & $\ldots$ & $\ldots$ \\
\hline Brazil & 388.0 & 6.9 & 377.2 & 7.5 & $\ldots$ & $\ldots$ & $\ldots$ \\
\hline Canada & 30.5 & 0.5 & 30.6 & 0.6 & $\ldots$ & $\ldots$ & $\ldots$ \\
\hline Denmark & 0.0 & 0.0 & 0.0 & 0.0 & $\ldots$ & $\ldots$ & $\ldots$ \\
\hline France & 1573.7 & 28.1 & 1453.4 & 28.8 & $\ldots$ & $\ldots$ & $\ldots$ \\
\hline Germany & 312.3 & 5.6 & 300.7 & 6.0 & $\ldots$ & $\cdots$ & $\ldots$ \\
\hline Ireland & 0.0 & 0.0 & 0.0 & 0.0 & $\ldots$ & $\ldots$ & $\ldots$ \\
\hline Italy & 188.3 & 3.4 & 182.1 & 3.6 & $\ldots$ & $\ldots$ & $\ldots$ \\
\hline Netherlands & 0.0 & 0.0 & 0.0 & 0.0 & $\ldots$ & $\ldots$ & $\ldots$ \\
\hline Russia & 161.3 & 2.9 & 120.0 & 2.4 & $\ldots$ & $\ldots$ & $\ldots$ \\
\hline Spain & 440.0 & 7.8 & 418.4 & 8.3 & $\ldots$ & $\ldots$ & $\ldots$ \\
\hline Switzerland & 17.4 & 0.3 & 16.6 & 0.3 & $\ldots$ & $\ldots$ & $\ldots$ \\
\hline United Kingdom & 170.4 & 3.0 & 152.7 & 3.0 & $\ldots$ & $\ldots$ & $\ldots$ \\
\hline United States & 37.5 & 0.7 & 34.5 & 0.7 & $\cdots$ & $\cdots$ & $\ldots$ \\
\hline Other official bilateral & 542.4 & 9.7 & 480.5 & 9.5 & 342.9 & 333.1 & 15.7 \\
\hline Post-cutoff date & 297.6 & 5.3 & 235.7 & 4.7 & 235.7 & 235.7 & 11.1 \\
\hline Pre-cutoff date & 244.8 & 4.4 & 244.8 & 4.8 & 107.2 & 97.4 & 4.6 \\
\hline ODA & 143.0 & 2.5 & 143.0 & 2.8 & 80.2 & 76.8 & 3.6 \\
\hline Non-ODA & 101.8 & 1.8 & 101.8 & 2.0 & 27.0 & 20.5 & 1.0 \\
\hline \multicolumn{8}{|l|}{ by country: } \\
\hline Algeria & 21.6 & 0.4 & 21.6 & 0.4 & 4.4 & 4.4 & 0.2 \\
\hline Angola & 80.2 & 1.4 & 80.2 & 1.6 & 16.1 & 16.1 & 0.8 \\
\hline Bulgaria $^{5}$ & 0.0 & 0.0 & 0.0 & 0.0 & 0.3 & 0.0 & 0.0 \\
\hline China $^{6}$ & 297.6 & 5.3 & 235.7 & 4.7 & 238.4 & 235.7 & 11.1 \\
\hline $\mathrm{Cuba}^{7}$ & 0.0 & 0.0 & 0.0 & 0.0 & 0.0 & 0.0 & 0.0 \\
\hline Saudi Arabia & 67.9 & 1.2 & 67.9 & 1.3 & 33.0 & 33.0 & 1.6 \\
\hline Kuwait & 56.8 & 1.0 & 56.8 & 1.1 & 33.5 & 33.5 & 1.6 \\
\hline Libya $^{8}$ & 0.0 & 0.0 & 0.0 & 0.0 & 6.3 & 0.0 & 0.0 \\
\hline Luxembourg & 0.0 & 0.0 & 0.0 & 0.0 & 0.0 & 0.0 & 0.0 \\
\hline Romania $^{9}$ & 0.0 & 0.0 & 0.0 & 0.0 & 0.4 & 0.0 & 0.0 \\
\hline United Arab Emirates & 18.3 & 0.3 & 18.3 & 0.4 & 10.3 & 10.3 & 0.5 \\
\hline Commercial $^{10}$ & 1207.2 & 21.5 & 1108.1 & 21.9 & 992.8 & 795.1 & 37.5 \\
\hline of which: London Club ${ }^{11}$ & 453.9 & 8.1 & 357.5 & 7.1 & 554.5 & 357.5 & 16.9 \\
\hline
\end{tabular}

${ }^{1}$ Information based on latest end December 2008 data available at completion point before signing bilateral agreements referring to the December 2008 Paris Club agreement .

2 Includes Naples flows, as well as Cologne flow and cancellations in the interim period from Paris Club creditors. The debt stock as of

December 2008 is (based on data available at completion point) before signing bilateral agreements referring to December 2008 Paris Club agreement.

${ }^{3}$ Assumes full delivery of HIPC assistance as of end-December 2008.

${ }^{4}$ Paris Club creditors deliver their share of assistance as a group. Actual delivery modalities are defined on a case-by-case basis. The bilateral agreements have been signed with all Paris Club creditors with the exception of Brazil, the UK and Russia.

${ }^{5}$ An agreement cancelling 77 percent of the claims was signed in 2008 and remaining claims have been paid.

${ }^{6}$ Congo has contracted that only one new loan from China in the interim period. A loan that was signed with China in 2003 was disbursed only after 2004

${ }^{7}$ All the claims have been paid in 2006 without any provision of relief.

${ }^{8}$ An agreement cancelling 80 percent of the claims was signed in 2008 and remaining claims have been paid.

${ }_{9}^{9}$ An agreement cancelling 77.7 percent of the claims was signed in 2008 and remaining claims have been paid.

${ }^{10}$ HIPC comparable cancellations and reschedulings have been provided by some commercial creditors. In December 2008 the Republic of Congo also settled all of its claims to litigating creditors by paying a total amount of US $\$ 939$ million.

${ }^{11}$ A commercial debt restructuring agreement with the London Club was finalized in November 2007. The agreement entailed the issuance of US $\$ 477$ million of Eurobonds maturing in 2029 with 5 percent paid at signing. Creditors holding 92 percent of this eligible debt participated in this agreement. 
Table 6. Republic of Congo: Net Present Value of External Debt (In millions of U.S. dollars, unless otherwise indicated)



Sources: Congolese authorities; and World Bank and Fund staff estimates and projections.

${ }^{1}$ Refers to public and publicly guaranteed external debt only and is discounted on the basis of the average commercial interest reference rate for the respective currency, derived over the six-month period prior to the latest date for which actual data are available (September 2008).

${ }^{2}$ Assumes a stock-of-debt operation on Naples terms (67 percent NPV reduction) as of end December-2008, and at least comparable action by other official bilateral and commercial creditors.

${ }^{3}$ For 2008 only, figure represents NPV of total Multilateral debt after conditional delivery of HIPC assistance through end-December 2009. From 2009 onwards, figures reflect full HIPC delivery.

${ }^{4} \mathrm{NPV}$ of total debt assuming the entire HIPC Initiative assistance is fully delivered as of end December-2008.

${ }^{5}$ Includes additional debt relief provided on a voluntary basis by the Paris Club beyond the requirements of the enhanced HIPC framework as specified on Table 12

${ }^{6}$ This corresponds to the situation after additional bilateral relief for Paris Club Creditors. 
Table 7. Republic of Congo: External Debt Service After Full Implementation of Debt-Relief Mechanisms (In millions of U.S. dollars, unless otherwise indicated)

\begin{tabular}{|c|c|c|c|c|c|c|c|c|c|c|c|}
\hline & \multirow[b]{2}{*}{2009} & \multirow[b]{2}{*}{2010} & \multirow[b]{2}{*}{2011} & \multirow[b]{2}{*}{2012} & \multirow[b]{2}{*}{2013} & \multirow[b]{2}{*}{2018} & \multirow[b]{2}{*}{2023} & \multirow[b]{2}{*}{2028} & \multirow[b]{2}{*}{2029} & \multicolumn{2}{|c|}{ Annual Average } \\
\hline & & & & & & & & & & 2009-2018 & 2019-2029 \\
\hline \multicolumn{12}{|l|}{ After traditional debt-relief mechanisms ${ }^{1}$} \\
\hline Total debt service including new borrowing & 374.3 & 740.8 & 706.4 & 676.2 & 606.1 & 289.9 & 349.9 & 421.0 & 433.2 & 439.3 & 368.2 \\
\hline Total debt service on outstanding debt & 371.3 & 737.2 & 702.0 & 666.0 & 591.0 & 202.6 & 210.7 & 282.4 & 298.7 & 407.6 & 234.5 \\
\hline Multilateral & 26.8 & 28.5 & 30.8 & 33.6 & 31.8 & 15.6 & 16.6 & 15.6 & 12.8 & 25.3 & 15.5 \\
\hline African Development Bank & 11.8 & 11.2 & 10.6 & 10.0 & 9.5 & 0.0 & 0.0 & 0.0 & 0.0 & 6.2 & 0.0 \\
\hline BADEA & 2.3 & 2.4 & 2.5 & 2.6 & 2.5 & 0.0 & 0.0 & 0.0 & 0.0 & 1.2 & 0.0 \\
\hline European Union & 2.2 & 2.2 & 2.2 & 2.2 & 2.2 & 1.7 & 1.7 & 0.4 & 0.4 & 2.1 & 1.1 \\
\hline IFAD & 0.1 & 0.1 & 0.1 & 0.1 & 0.1 & 0.3 & 0.3 & 0.3 & 0.3 & 0.2 & 0.3 \\
\hline IDA & 7.6 & 7.4 & 7.9 & 8.8 & 9.6 & 12.6 & 14.0 & 14.0 & 11.2 & 10.3 & 13.4 \\
\hline IMF & 0.1 & 2.6 & 5.0 & 7.4 & 7.4 & 0.4 & 0.0 & 0.0 & 0.0 & 3.9 & 0.0 \\
\hline OFID & 2.2 & 2.1 & 2.0 & 1.9 & 0.0 & 0.0 & 0.0 & 0.0 & 0.0 & 0.8 & 0.0 \\
\hline Official bilateral & 189.2 & 401.6 & 385.4 & 367.5 & 356.6 & 134.3 & 121.0 & 162.3 & 173.3 & 237.3 & 138.2 \\
\hline Paris Club & 152.9 & 363.1 & 346.9 & 329.7 & 319.3 & 110.0 & 109.9 & 150.7 & 161.2 & 201.2 & 126.6 \\
\hline Commercial & 155.3 & 307.0 & 285.8 & 264.9 & 202.6 & 52.7 & 73.1 & 104.5 & 112.6 & 145.0 & 80.8 \\
\hline \multicolumn{12}{|l|}{ After enhanced HIPC assistance } \\
\hline Total debt service including new borrowing & 228.5 & 296.8 & 286.4 & 491.4 & 476.7 & 218.8 & 278.1 & 302.6 & 303.3 & 354.8 & 277.1 \\
\hline Total debt service on outstanding debt & 225.5 & 293.2 & 282.0 & 481.2 & 461.6 & 131.4 & 139.0 & 164.0 & 168.8 & 323.0 & 143.4 \\
\hline Multilateral & 21.2 & 19.5 & 20.8 & 24.5 & 26.5 & 10.0 & 16.6 & 15.6 & 12.8 & 18.6 & 14.5 \\
\hline African Development Bank & 11.8 & 11.2 & 10.6 & 10.0 & 9.5 & 0.0 & 0.0 & 0.0 & 0.0 & 6.2 & 0.0 \\
\hline African Development Fund & 0.5 & 0.6 & 0.6 & 0.6 & 0.6 & 0.7 & 0.6 & 0.9 & 0.8 & 0.6 & 0.7 \\
\hline BADEA & 2.3 & 0.0 & 1.6 & 2.6 & 2.5 & 0.0 & 0.0 & 0.0 & 0.0 & 0.9 & 0.0 \\
\hline European Union & 0.2 & 2.2 & 2.2 & 2.2 & 2.2 & 1.7 & 1.7 & 0.4 & 0.4 & 1.9 & 1.1 \\
\hline IFAD & 0.1 & 0.0 & 0.0 & 0.1 & 0.1 & 0.3 & 0.3 & 0.3 & 0.3 & 0.2 & 0.3 \\
\hline IDA & 4.0 & 3.9 & 4.2 & 4.8 & 5.3 & 7.0 & 14.0 & 14.0 & 11.2 & 5.7 & 12.4 \\
\hline IMF & 0.1 & 1.6 & 1.6 & 4.1 & 6.4 & 0.4 & 0.0 & 0.0 & 0.0 & 2.9 & 0.0 \\
\hline OFID & 2.2 & 0.0 & 0.0 & 0.2 & 0.0 & 0.0 & 0.0 & 0.0 & 0.0 & 0.2 & 0.0 \\
\hline Official bilateral & 109.4 & 135.4 & 136.8 & 346.0 & 334.5 & 86.0 & 91.0 & 117.8 & 125.5 & 197.5 & 97.5 \\
\hline Paris Club & 77.4 & 102.8 & 103.8 & 313.0 & 301.5 & 63.9 & 82.3 & 109.6 & 116.9 & 165.0 & 88.6 \\
\hline \multicolumn{12}{|l|}{ After bilateral debt relief beyond HIPC ${ }^{2}$} \\
\hline Total debt service including new borrowing & 217.2 & 238.6 & 221.2 & 378.0 & 365.4 & 153.4 & 193.9 & 190.5 & 183.9 & 256.2 & 186.6 \\
\hline Total debt service on outstanding debt & 214.3 & 235.0 & 216.8 & 367.9 & 350.3 & 66.1 & 54.7 & 51.9 & 49.4 & 224.5 & 53.0 \\
\hline Multilateral & 21.2 & 19.5 & 20.8 & 24.5 & 26.5 & 10.0 & 16.6 & 15.6 & 12.8 & 18.6 & 14.7 \\
\hline Official bilateral & 109.1 & 81.9 & 76.6 & 237.9 & 228.9 & 22.0 & 8.1 & 7.1 & 7.4 & 126.0 & 8.2 \\
\hline Paris Club & 77.4 & 49.6 & 43.9 & 205.2 & 196.1 & 0.2 & 0.0 & 0.0 & 0.0 & 93.8 & 0.0 \\
\hline Other official bilateral & 31.8 & 32.3 & 32.7 & 32.7 & 32.7 & 21.7 & 8.1 & 7.1 & 7.4 & 32.2 & 8.2 \\
\hline Commercial & 84.0 & 133.7 & 119.4 & 105.4 & 94.9 & 34.1 & 30.1 & 29.3 & 29.2 & 79.9 & 30.1 \\
\hline After MDRI assistance and bilateral debt & ef beyor & d HIPC & ssistan & & & & & & & & \\
\hline Total debt service including new borrowing & 217.2 & 234.8 & 215.6 & 372.1 & 359.5 & 147.6 & 182.5 & 179.5 & 175.7 & 251.1 & 176.5 \\
\hline Total debt service on outstanding debt & 214.3 & 231.1 & 211.2 & 362.0 & 344.4 & 60.3 & 43.4 & 40.9 & 41.2 & 219.3 & 42.9 \\
\hline Multilateral & 21.2 & 15.6 & 15.2 & 18.7 & 20.6 & 4.2 & 5.2 & 4.6 & 4.5 & 13.4 & 4.6 \\
\hline African Development Bank & 11.8 & 11.2 & 10.6 & 10.0 & 9.5 & 0.0 & 0.0 & 0.0 & 0.0 & 6.2 & 0.0 \\
\hline African Development Fund & 0.5 & 0.3 & 0.1 & 0.1 & 0.1 & 0.2 & 0.2 & 0.4 & 0.4 & 0.2 & 0.3 \\
\hline BADEA & 2.3 & 0.0 & 1.6 & 2.6 & 2.5 & 0.0 & 0.0 & 0.0 & 0.0 & 0.9 & 0.0 \\
\hline European Union & 0.2 & 2.2 & 2.2 & 2.2 & 2.2 & 1.7 & 1.7 & 0.4 & 0.4 & 1.9 & 1.2 \\
\hline IFAD & 0.1 & 0.0 & 0.0 & 0.1 & 0.1 & 0.3 & 0.3 & 0.3 & 0.3 & 0.2 & 0.3 \\
\hline IDA & 4.0 & 1.8 & 0.6 & 0.8 & 1.3 & 1.7 & 3.1 & 3.4 & 3.4 & 1.7 & 2.8 \\
\hline IMF & 0.1 & 0.1 & 0.1 & 2.6 & 4.9 & 0.4 & 0.0 & 0.0 & 0.0 & 2.2 & 0.0 \\
\hline OFID & 2.2 & 0.0 & 0.0 & 0.2 & 0.0 & 0.0 & 0.0 & 0.0 & 0.0 & 0.2 & 0.0 \\
\hline Official bilateral $^{2}$ & 109.1 & 81.9 & 76.6 & 237.9 & 228.9 & 22.0 & 8.1 & 7.1 & 7.4 & 126.0 & 8.2 \\
\hline Commercial & 84.0 & 133.7 & 119.4 & 105.4 & 94.9 & 34.1 & 30.1 & 29.3 & 29.2 & 79.9 & 30.1 \\
\hline Memorandum items: & & & & & & & & & & & \\
\hline Debt service of new borrowing & 3.0 & 3.6 & 4.4 & 10.2 & 15.1 & 87.3 & 139.1 & 138.6 & 134.5 & 31.8 & 133.7 \\
\hline Nominal debt relief & & & & & & & & & & & \\
\hline Under the enhanced HIPC initiative & 145.8 & 444.0 & 420.0 & 184.8 & 129.4 & 71.2 & 71.7 & 118.4 & 129.9 & 84.5 & 91.1 \\
\hline Under the MDRI & 0.0 & 3.9 & 5.6 & 5.9 & 6.0 & 5.8 & 11.3 & 11.0 & 8.2 & 5.1 & 9.9 \\
\hline
\end{tabular}

Sources: Congolese authorities; and World Bank and Fund staff estimates and projections.

${ }^{1}$ Assumes a stock-of-debt operation on Naples terms (67 percent NPV reduction) as of end December-2008, and at least comparable action by other official bilateral creditors.

${ }^{2}$ Includes additional debt relief provided on a voluntary basis by the Paris Club beyond the requirements of the enhanced HIPC framework. 
Table 8. Republic of Congo: Key External Debt Indicators, 2008-28 (in percent, unless otherwise indicated)

\begin{tabular}{|c|c|c|c|c|c|c|c|c|c|c|c|c|}
\hline & \multirow{2}{*}{$\begin{array}{c}\text { Actual } \\
2008\end{array}$} & \multicolumn{9}{|c|}{ Estimate } & \multicolumn{2}{|c|}{ Annual Averages } \\
\hline & & 2009 & 2010 & 2011 & 2012 & 2013 & 2018 & 2023 & 2028 & 2029 & $\begin{array}{r}2008 \text { - } \\
2018 \\
\end{array}$ & $\begin{array}{r}2019 \\
2029 \\
\end{array}$ \\
\hline \multicolumn{13}{|l|}{ After traditional debt relief } \\
\hline NPV of debt-to-GDP ratio & 44 & 58 & 38 & 32 & 29 & 28 & 27 & 17 & 8 & 6 & 33 & 16 \\
\hline NPV of debt-to-exports ratio ${ }^{2,5}$ & 67 & 70 & 56 & 48 & 38 & 35 & 47 & 48 & 32 & 27 & 46 & 45 \\
\hline NPV of debt-to-exports ratio (existing debt only) ${ }^{2,5}$ & 67 & 66 & 51 & 41 & 31 & 26 & 31 & 31 & 19 & 14 & 36 & 28 \\
\hline NPV of debt-to-revenues ratio ${ }^{5}$ & 86 & 161 & 81 & 66 & 58 & 54 & 56 & 41 & 20 & 16 & 70 & 38 \\
\hline Debt service-to-revenue ratio ${ }^{3}$ & $\ldots$ & 12 & 13 & 11 & 10 & 9 & 4 & 5 & 5 & 5 & 7 & 5 \\
\hline \multicolumn{13}{|l|}{ After enhanced HIPC assistance } \\
\hline NPV of debt-to-GDP ratio & 44 & 54 & 31 & 29 & 27 & 27 & 21 & 14 & 7 & 6 & 28 & 13 \\
\hline NPV of debt-to-exports ratio ${ }^{2,5}$ & 67 & 66 & 46 & 43 & 35 & 34 & 37 & 39 & 29 & 26 & 40 & 36 \\
\hline NPV of debt-to-exports ratio (existing debt only) ${ }^{2,5}$ & 67 & 62 & 40 & 36 & 28 & 25 & 21 & 21 & 15 & 13 & 29 & 20 \\
\hline NPV of debt-to-revenues ratio ${ }^{5}$ & 86 & 152 & 67 & 59 & 53 & 52 & 44 & 33 & 18 & 15 & 61 & 31 \\
\hline Debt service-to-export ratio ${ }^{5}$ & $\ldots$ & 4 & 3 & 3 & 5 & 5 & 3 & 5 & 5 & 5 & 4 & 5 \\
\hline Debt service-to-revenue ratio ${ }^{3}$ & $\cdots$ & 7 & 5 & 4 & 7 & 7 & 3 & 4 & 3 & 3 & 6 & 4 \\
\hline NPV of debt-to-GDP ratio & 42 & 52 & 19 & 18 & 17 & 16 & 13 & 9 & 4 & 4 & 20 & 8 \\
\hline NPV of debt-to-exports ratio ${ }^{2,5}$ & 63 & 63 & 28 & 27 & 22 & 21 & 23 & 24 & 18 & 16 & 27 & 22 \\
\hline NPV of debt-to-exports ratio (existing debt only) ${ }^{2,5}$ & 63 & 59 & 23 & 20 & 14 & 11 & 7 & 7 & 4 & 3 & 17 & 6 \\
\hline NPV of debt-to-revenues ratio ${ }^{5}$ & 81 & 146 & 41 & 37 & 33 & 32 & 28 & 20 & 11 & 10 & 43 & 19 \\
\hline Debt service-to-export ratio ${ }^{5}$ & $\ldots$ & 3 & 2 & 2 & 4 & 4 & 2 & 3 & 3 & 3 & 3 & 3 \\
\hline Debt service-to-revenue ratio ${ }^{3}$ & $\cdots$ & 7 & 4 & 3 & 6 & 5 & 2 & 3 & 2 & 2 & 4 & 3 \\
\hline \multicolumn{13}{|l|}{ After MDRI ${ }^{5}$} \\
\hline NPV of debt-to-GDP ratio & 41 & 51 & 18 & 17 & 16 & 15 & 12 & 8 & 4 & 3 & 19 & 8 \\
\hline NPV of debt-to-exports ratio ${ }^{2,5}$ & 61 & 62 & 27 & 25 & 21 & 20 & 22 & 23 & 17 & 16 & 26 & 21 \\
\hline NPV of debt-to-exports ratio (existing debt only) ${ }^{2,5}$ & 61 & 57 & 22 & 18 & 13 & 10 & 6 & 5 & 3 & 2 & 15 & 5 \\
\hline NPV of debt-to-revenues ratio ${ }^{5}$ & 80 & 142 & 39 & 35 & 31 & 30 & 26 & 19 & 11 & 9 & 41 & 18 \\
\hline Debt service-to-export ratio ${ }^{5}$ & $\ldots$ & 3 & 2 & 2 & 3 & 4 & 2 & 3 & 3 & 3 & 3 & 3 \\
\hline Debt service-to-revenue ratio ${ }^{3}$ & $\ldots$ & 7 & 4 & 3 & 5 & 5 & 2 & 3 & 2 & 2 & 4 & 2 \\
\hline Memorandum items: & \multicolumn{12}{|c|}{ (in millions of U.S. dollars) } \\
\hline NPV of debt after traditional debt relief & 4,777 & 4,948 & 4,591 & 4,263 & 3,944 & 3,680 & 3,622 & 2,962 & 1,829 & 1,530 & 4,024 & 2,793 \\
\hline Debt service after HIPC assistance & $\ldots$ & 228 & 297 & 286 & 491 & 477 & 219 & 278 & 303 & 303 & 355 & 274 \\
\hline NPV of debt after additional bilateral relief & 4,496 & 4,476 & 2,326 & 2,370 & 2,255 & 2,147 & 1,790 & 1,458 & 996 & 904 & 2,319 & 1,400 \\
\hline Debt service after additional bilateral relief & $\ldots$ & 217 & 239 & 221 & 378 & 365 & 153 & 194 & 191 & 184 & 256 & 187 \\
\hline NPV of debt after MDRI and additional bilateral relief ${ }^{4}$ & 4,391 & 4,368 & 2,216 & 2,260 & 2,147 & 2,039 & 1,689 & 1,379 & 958 & 873 & 2,213 & 1,326 \\
\hline Debt service after MDRI and additional bilateral relief ${ }^{4}$ & $\ldots$ & 217 & 235 & 216 & 372 & 359 & 148 & 183 & 180 & 176 & 251 & 177 \\
\hline GDP & 10,774 & 8,596 & 12,062 & 13,305 & 13,470 & 13,166 & 13,610 & 17,064 & 23,367 & 25,029 & 12,648 & 18,035 \\
\hline Exports of goods and services ${ }^{5}$ & 8,470 & 6,391 & 9,676 & 10,753 & 10,646 & 9,924 & 7,218 & 5,945 & 5,620 & 5,652 & 8,827 & 6,025 \\
\hline Exports of goods and services (3-year mvg. avg.) ${ }^{2,5}$ & 7,152 & 7,081 & 8,179 & 8,940 & 10,358 & 10,441 & 7,632 & 6,129 & 5,630 & 5,630 & 8,869 & 6,198 \\
\hline Government revenue $^{3}$ & 5,523 & 3,076 & 5,646 & 6,433 & 6,837 & 6,804 & 6,490 & 7,185 & 8,939 & 9,432 & 6,244 & 7,482 \\
\hline
\end{tabular}

Sources: Congolese authorities; and World Bank and Fund staff estimates and projections.

${ }^{1}$ All debt indicators refer to public and publicly guaranteed (PPG) debt and are defined after rescheduling, unless otherwise indicated.

${ }^{2}$ Based on a three-year average of exports on the previous year (e.g., export average over 2005-07 for NPV of debt-to-exports ratio in 2007).

${ }^{3}$ Revenues are defined as central government revenues, excluding grants.

${ }^{4}$ Assumes delivery of MDRI relief by IDA and IADB.

${ }^{5}$ As defined in IMF, Balance of Payments Manual, 5th edition, 1993. 
Table 9. Republic of Congo: Sensitivity Analysis, 2009-28 ${ }^{1}$

(In percent, unless otherwise indicated)

\begin{tabular}{|c|c|c|c|c|c|c|c|c|c|c|c|}
\hline & \multicolumn{9}{|c|}{ Projections } & \multicolumn{2}{|c|}{ Average } \\
\hline & 2009 & 2010 & 2011 & 2012 & 2013 & 2018 & 2023 & 2028 & 2029 & $\begin{array}{r}2008- \\
2018\end{array}$ & $\begin{array}{r}2019- \\
2029\end{array}$ \\
\hline \multicolumn{12}{|l|}{ A. Baseline Scenario } \\
\hline NPV of debt-to-revenue ratio ${ }^{2}$ & 72 & 39 & 35 & 31 & 30 & 26 & 19 & 11 & 9 & 34 & 18 \\
\hline Debt service-to-export ratio & 3 & 2 & 2 & 3 & 4 & 2 & 3 & 3 & 3 & 3 & 3 \\
\hline Debt service-to-revenue ratio & 7 & 4 & 3 & 5 & 5 & 2 & 3 & 2 & 2 & 4 & 2 \\
\hline \multicolumn{12}{|l|}{ Memorandum items (in millions of U.S. dollars) } \\
\hline of which: new debt & 303 & 449 & 614 & 779 & 947 & 1,248 & 1,060 & 786 & 733 & 927 & 1,025 \\
\hline Debt service & 217 & 235 & 216 & 372 & 359 & 148 & 183 & 180 & 176 & 251 & 177 \\
\hline of which: new debt & 3 & 4 & 4 & 10 & 15 & 87 & 139 & 139 & 135 & 32 & 134 \\
\hline Exports of goods and services, three year average & 7,081 & 8,179 & 8,940 & 10,358 & 10,441 & 7,632 & 6,129 & 5,630 & 5,630 & 8,869 & 6,198 \\
\hline Exports of goods and services ${ }^{3}$ & 6,391 & 9,676 & 10,753 & 10,646 & 9,924 & 7,218 & 5,945 & 5,620 & 5,652 & 8,827 & 6,025 \\
\hline Government revenue & 3,076 & 5,646 & 6,433 & 6,837 & 6,804 & 6,490 & 7,185 & 8,939 & 9,432 & 6,244 & 7,482 \\
\hline \multicolumn{12}{|l|}{ B. Sensitivity Analysis } \\
\hline NPV of debt-to-revenue ratio ${ }^{2}$ & 72 & 54 & 50 & 44 & 42 & 35 & 25 & 13 & 11 & 45 & 24 \\
\hline Debt senvice-to-export ratio & 3 & 3 & 3 & 5 & 5 & 3 & 4 & 4 & 3 & 4 & 3 \\
\hline Debt senvice-to-revenue ratio & 7 & 6 & 5 & 8 & 7 & 3 & 3 & 2 & 2 & 6 & 3 \\
\hline \multicolumn{12}{|l|}{ Memorandum items (in millions of U.S. dollars) } \\
\hline NPV of debt & 2,205 & 2,216 & 2,260 & 2,147 & 2,039 & 1,689 & 1,379 & 958 & 873 & 1,997 & 1,326 \\
\hline of which: new debt & 303 & 449 & 614 & 779 & 947 & 1,248 & 1,060 & 786 & 733 & 927 & 1,025 \\
\hline Debt senvice & 217 & 235 & 216 & 372 & 359 & 148 & 183 & 180 & 176 & 251 & 177 \\
\hline of which: new debt & 3 & 4 & 4 & 10 & 15 & 87 & 139 & 139 & 135 & 32 & 134 \\
\hline Exports of goods and services, three year average & 7,081 & 7,416 & 7,325 & 7,912 & 7,995 & 6,048 & 5,109 & 4,974 & 5,030 & 7,179 & 5,191 \\
\hline Exports of goods and services ${ }^{3}$ & 6,391 & 7,386 & 8,199 & 8,152 & 7,635 & 5,771 & 5,014 & 5,021 & 5,103 & 6,987 & 5,106 \\
\hline Government revenue & 3,076 & 4,102 & 4,563 & 4,866 & 4,878 & 4,819 & 5,560 & 7,270 & 7,730 & 4,598 & 5,843 \\
\hline \multicolumn{12}{|l|}{ B-2. Non oil GDP shock 5} \\
\hline NPV of debt-to-revenue ratio ${ }^{2}$ & 72 & 39 & 35 & 32 & 30 & 27 & 22 & 13 & 12 & 35 & 21 \\
\hline Debt senvice-to-export ratio & 3 & 2 & 2 & 4 & 4 & 2 & 3 & 4 & 4 & 3 & 3 \\
\hline Debt senvice-to-revenue ratio & 7 & 4 & 3 & 5 & 5 & 2 & 3 & 2 & 2 & 4 & 3 \\
\hline \multicolumn{12}{|l|}{ Memorandum items (in millions of U.S. dollars) } \\
\hline NPV of debt & 2,205 & 2,216 & 2,260 & 2,147 & 2,039 & 1,689 & 1,379 & 958 & 873 & 1,997 & 1,326 \\
\hline of which: new debt & 3 & 4 & 4 & 10 & 15 & 87 & 139 & 139 & 135 & 32 & 134 \\
\hline Exports of goods and services, three year average & 7,081 & 8,175 & 8,927 & 10,332 & 10,403 & 7,498 & 5,803 & 4,982 & 4,898 & 8,817 & 5,825 \\
\hline Exports of goods and services ${ }^{3}$ & 6,391 & 9,664 & 10,727 & 10,605 & 9,878 & 7,055 & 5,568 & 4,891 & 4,830 & 8,759 & 5,597 \\
\hline Government revenue & 3,076 & 5,629 & 6,397 & 6,775 & 6,712 & 6,156 & 6,367 & 7,242 & 7,497 & 6,111 & 6,531 \\
\hline
\end{tabular}

Sources: Congolese authorities; and World Bank and Fund staff estimates and projections.

${ }^{1}$ All debt indicators refer to public and publicly guaranteed debt after full delivery of debt relief (including debt relief beyond the HIPC Initiative and MDRI relief).

${ }^{2}$ Based on the end of period fiscal revenues excluding grants

${ }^{3}$ Exports of goods and services as defined in IMF, Balance of Payments Manual, 5th edition, 1993.

${ }^{4} 25 \%$ lower than main scenario.

${ }^{5} 2$ percentage points lower than main scenario. 
Table 10. Republic of Congo: Delivery of IMF Assistance under the Enhanced HIPC Initiative and the MDRI, 2006-15

(In millions of SDRs, unless otherwise indicated)

\begin{tabular}{|c|c|c|c|c|c|c|c|c|c|c|c|}
\hline & \multirow{2}{*}{$\begin{array}{r}2006 \\
\text { Mar-Dec }\end{array}$} & \multirow[t]{2}{*}{2007} & \multirow[t]{2}{*}{2008} & \multirow[t]{2}{*}{2009} & \multicolumn{2}{|c|}{2010} & \multirow[t]{2}{*}{2011} & \multirow[t]{2}{*}{2012} & \multirow[t]{2}{*}{2013} & \multirow[t]{2}{*}{2014} & \multirow[t]{2}{*}{2015} \\
\hline & & & & & Jan & Feb-Dec & & & & & \\
\hline \multicolumn{12}{|l|}{ I. Pre-MDRI Debt relief (under the HIPC Initiative only) ${ }^{2}$} \\
\hline $\begin{array}{l}\text { HIPC-eligible debt service due on IMF obligations }{ }^{3} \\
\text { Principal } \\
\text { Interest }\end{array}$ & $\begin{array}{l}1.5 \\
1.4 \\
0.1\end{array}$ & $\begin{array}{l}0.1 \\
- \\
0.1\end{array}$ & $\begin{array}{l}0.1 \\
- \\
0.1\end{array}$ & $\begin{array}{l}0.1 \\
- \\
0.1\end{array}$ & $\begin{array}{l}- \\
- \\
-\end{array}$ & $\begin{array}{l}1.6 \\
1.6 \\
0.1\end{array}$ & $\begin{array}{l}3.2 \\
3.1 \\
0.1\end{array}$ & $\begin{array}{l}3.2 \\
3.1 \\
0.0\end{array}$ & $\begin{array}{l}3.2 \\
3.1 \\
0.0\end{array}$ & $\begin{array}{l}3.2 \\
3.1 \\
0.0\end{array}$ & $\begin{array}{l}1.6 \\
1.6 \\
0.0\end{array}$ \\
\hline $\begin{array}{l}\text { HIPC assistance--deposits into member's Umbrella Account } \\
\text { Interim assistance } \\
\text { Completion point disbursement } \\
\text { Completion point assistance }{ }^{4} \\
\text { Completion point interest }^{5}\end{array}$ & & & 0.1 & 0.8 & $\begin{array}{l}5.4 \\
4.5 \\
0.9\end{array}$ & & & & & & \\
\hline $\begin{array}{l}\text { IMF assistance--drawdown schedule from member's Umbrella Account } \\
\text { IMF assistance without interest } \\
\text { Estimated interest earnings }{ }^{5}\end{array}$ & $\begin{array}{l}- \\
-\end{array}$ & $\begin{array}{l}- \\
-\end{array}$ & $\begin{array}{l}0.04 \\
0.04 \\
-\end{array}$ & $\begin{array}{r}0.08 \\
0.08 \\
0.0\end{array}$ & $\begin{array}{l}- \\
- \\
-\end{array}$ & $\begin{array}{l}0.5 \\
0.4 \\
0.1\end{array}$ & $\begin{array}{l}1.3 \\
1.0 \\
0.4\end{array}$ & $\begin{array}{l}1.4 \\
1.0 \\
0.4\end{array}$ & $\begin{array}{l}1.4 \\
1.1 \\
0.3\end{array}$ & $\begin{array}{l}1.4 \\
1.3 \\
0.1\end{array}$ & $\begin{array}{l}0.6 \\
0.6 \\
0.1\end{array}$ \\
\hline Debt service due on current IMF obligations after IMF assistance & 1.5 & 0.1 & 0.04 & 0.001 & - & 1.1 & 1.9 & 1.8 & 1.8 & 1.8 & 1.0 \\
\hline Delivery schedule of IMF assistance (in percent of the total assistance; on a flow basis) & - & - & 0.7 & 1.4 & - & 7.3 & 17.6 & 17.6 & 21.0 & 24.0 & 10.3 \\
\hline Share of debt service due on IMF obligations covered by HIPC assistance (in percent) & - & - & 49.3 & 99.1 & - & 33.0 & 41.6 & 43.0 & 44.0 & 43.8 & 39.2 \\
\hline $\begin{array}{l}\text { Proportion (in percent) of each repayment falling due during the period to be paid } \\
\text { by HIPC assistance from the principal deposited in Umbrella Account }\end{array}$ & - & - & 98.0 & 99.1 & - & 25.2 & 30.2 & 30.2 & 36.1 & 41.1 & 35.3 \\
\hline II. Post-MDRI Debt relief (under both MDRI and HIPC Initiatives) & & & & & 10.9 & & & & & & \\
\hline Projected pre MDRI cutoff date debt at completion point ${ }^{6}$ & & & & & 7.9 & & & & & & \\
\hline $\begin{array}{l}\text { Delivery of debt relief (on stock basis): } \\
\text { from the MDRI-II Trust }{ }^{7} \\
\text { from the HIPC Umbrella Account }{ }^{8}\end{array}$ & & & & & $\begin{array}{l}4.8 \\
3.1\end{array}$ & & & & & & \\
\hline Delivery of remaining HIPC assistance for post MDRI cutoff date debt (on stock basis): & & & & & 3.1 & & & & & & \\
\hline III. Debt service due to the IMF after HIPC and MDRI debt relief ${ }^{9}$ & 1.5 & 0.1 & 0.1 & 0.05 & - & 0.1 & 0.1 & 1.7 & 3.2 & 3.5 & 3.7 \\
\hline
\end{tabular}

Source: Fund staff estimates and projections.

1 Total IMF assistance under the enhanced HIPC Initiative is SDR 5.395 million in NPV terms calculated on the basis of data available at the decision point, excluding interest earned on Republic of Congo's account and on committed but undisbursed amounts as described in footnote 5. IMF assistance committed at the decision point is adjusted downwards from SDR 5.637 million to SDR 5.395 million owing to data revisions. and on committed but undisbursed amounts as described in footnote 5. IMF a

2 Estimated delivery of HIPC assistance in the absence of MDRI decision.
3 Data as of decision point. Interest obligations exclude net SDR charges and assessments which are not eligible for HIPC assistance.

${ }^{4} \mathrm{~A}$ final disbursement of SDR 4.5 million will be deposited into Republic of Congo's Umbrella Account at the completion point in January 2010.

5 Includes estimated interest earnings on: (a) amounts held in Republic of Congo's Umbrella Account; and (b) up to the completion point, amounts committed but not yet disbursed. The projected interest earnings are estimated based on assumed interest rates which are gradually rising to 4.5 percent in 2015; actual interest earnings may be higher or lower.

are estimated based on assumed interest rates which are gradually
${ }^{6}$ Associated with disbursements made prior to December $31,2004$.

7 Credit outstanding at end-2004 that has not been repaid by the member or with HIPC assistance at the completion point and is not scheduled to be repaid by HIPC assistance, as defined in the MDRI-II Trust Instrument.

$8 \mathrm{It}$ is estimated that 50 percent of the completion point HIPC assistance would be used for financing of the MDRI-eligible debt.

${ }^{9}$ Estimates as of end-August 2009 
Table 11. Republic of Congo: Delivery of World Bank HIPC Assistance and MDRI, 2006 to 2044 /1

(In millions of U.S. dollars, unless otherwise indicated)

\begin{tabular}{|c|c|c|c|c|c|c|c|c|c|c|c|c|c|c|c|c|c|c|c|c|c|c|c|}
\hline \multirow[b]{3}{*}{ 1. Relief under the Enhanced HIPC Initiative } & \multicolumn{4}{|c|}{ Actual } & \multicolumn{17}{|c|}{ Projection } & \multirow{2}{*}{\multicolumn{2}{|c|}{$\begin{array}{c}\text { Averages } \\
2006-202 \\
2025204\end{array}$}} \\
\hline & 2006 & 2007 & 2008 & 2009 & 201 & 102 & 2011 & 2012 & 2013 & 2014 & 2015 & 2016 & 2017 & 2018 & 2019 & 2020 & 2025 & 2030 & 2035 & 52040 & 2044 & & \\
\hline & & & & & & & & & & & & & & & & & & & & & & & \\
\hline World Bank debt service before HIPC relief & 7.3 & 7.3 & 7.3 & 7.2 & & 7.4 & 7.9 & 8.8 & 9.6 & 11.1 & 12.8 & 12.7 & 12.6 & 12.6 & 12.5 & 12.4 & 14.3 & 7.9 & 6.5 & $5 \quad 6.2$ & $2 \quad 0.7$ & 10.9 & \\
\hline Principal & 5.3 & 5.3 & 5.3 & 5.3 & & 5.2 & 5.7 & 6.7 & 7.5 & 9.1 & 10.9 & 10.9 & 10.9 & 10.9 & 10.9 & 10.9 & 13.3 & 7.3 & 6.1 & 16.1 & $\begin{array}{ll}1 & 0.7\end{array}$ & 9.2 & \\
\hline Interest & 2.0 & 2.0 & 2.0 & 1.9 & & 2.2 & 2.1 & 2.1 & 2.0 & 2.0 & 1.9 & 1.8 & 1.7 & 1.7 & 1.6 & 1.5 & 1.0 & 0.6 & 0.3 & $\begin{array}{lll}3 & 0.1 & \end{array}$ & 0.0 & 1.7 & \\
\hline World Bank debt service after HIPC relief & 4.7 & 3.7 & 3.7 & 3.6 & & 3.9 & 4.2 & 4.8 & 5.3 & 6.1 & 7.1 & 7.1 & 7.1 & 7.0 & 7.0 & 6.9 & 14.3 & 7.9 & 6.5 & $5 \quad 6.2$ & $2 \quad 0.7$ & 7.5 & \\
\hline World Bank assistance ${ }^{2}$ & 2.7 & 3.6 & 3.6 & 3.6 & & 3.5 & 3.7 & 4.0 & 4.3 & 5.0 & 5.7 & 5.6 & 5.6 & 5.6 & 5.5 & 5.5 & 0.0 & 0.0 & 0.0 & $\begin{array}{ll}0 & 0.0\end{array}$ & 0.0 & 3.4 & \\
\hline
\end{tabular}

2. Relief under the MDRI $^{3}$

Projected stock of IDA credits outstanding at implementation date ${ }^{4}$

291.1

Debt stock reduction on eligible credits ${ }^{5}$

Due to HIPC relief ${ }^{6}$

Remaining IDA credits after MDRI relief

207.3

46.2

83.7

IDA debt service relief under the MDRI

$\begin{array}{llllllllllllllll}2.1 & 3.6 & 3.9 & 4.0 & 4.7 & 5.4 & 5.4 & 5.4 & 5.3 & 5.3 & 5.2 & 10.8 & 4.5 & 3.2 & 3.0 & 0.0\end{array}$

$6.5 \quad 4.2$

Debt service due to IDA after HIPC relief and the MDRI

$\begin{array}{llllllllllllllll}1.8 & 0.6 & 0.8 & 1.3 & 1.4 & 1.7 & 1.7 & 1.7 & 1.7 & 1.7 & 1.7 & 3.5 & 3.4 & 3.3 & 3.2 & 0.7\end{array}$

\section{Memorandum item:}

\section{Debt relief}

Debt service to IDA covered by HIPC (in percent)

Debt service to IDA covered by HIPC and MDRI (in percent)

Interim Assistance ${ }^{8}$

Interim relief as percent of total ${ }^{8}$

IDA debt service relief under the MDRI (in millions of SDR ${ }^{9}$

Sources: IDAstaff estimates

${ }^{1}$ For the 2006-2009 period, debt service and debt relief is estimated on debt outstanding as of end-December 2004, using end-2004 exchange rates. For the projection period beginning in 2010, debt service is ${ }^{2}$ Total HIPC debt relief amounts to US $\$ 47$ million in NPV terms, using end-2004 discount and exchange rates.

${ }^{3}$ Stock of debt and debt service denominated in SDRs are converted into U.S. dollar by applying the end-2008 exchange rate.

${ }^{4}$ Stock of debt outstanding as of end-December 2008.

${ }^{5}$ Debt disbursed as of end-December 2003 and still outstanding as of end-December 2008.

${ }^{6} \mathrm{HIPC}$ relief is assumed to proportionally reduce repayments of principal and charges on IDA credits disbursed as of end-December 2004 and still outstanding as of end-December 2008.

${ }^{7}$ Using end-2008 exchange rates.

${ }^{8}$ In end-2004 net present value (NPV) terms.

${ }^{9}$ For SDR-denominated IDA credits, debt relief under the MDRI is estimated as 100 percent of SDR-based debt service minus USD-based debt relief under the Enhanced HIPC Initiative. HIPC debt relief is

equivalent amounts by applying the foreign exchange reference rate of 1.52448 agreed by donors under the latest regular IDA replenishment. For USD-denominated IDA credits, debt relief under the MDRI is

percent of USD-based debt service minus USD-based debt relief under the Enhanced HIPC Initiative. The resulting MDRI debt relief amounts are converted into SDR equivalent amounts by applying the foreign

reference rates agreed by donors under the latest regular IDA replenishment. 
Table 12. Paris Club Creditors' Delivery of Debt Relief Under Bilateral Initiatives Beyond the HIPC Initiative ${ }^{1}$

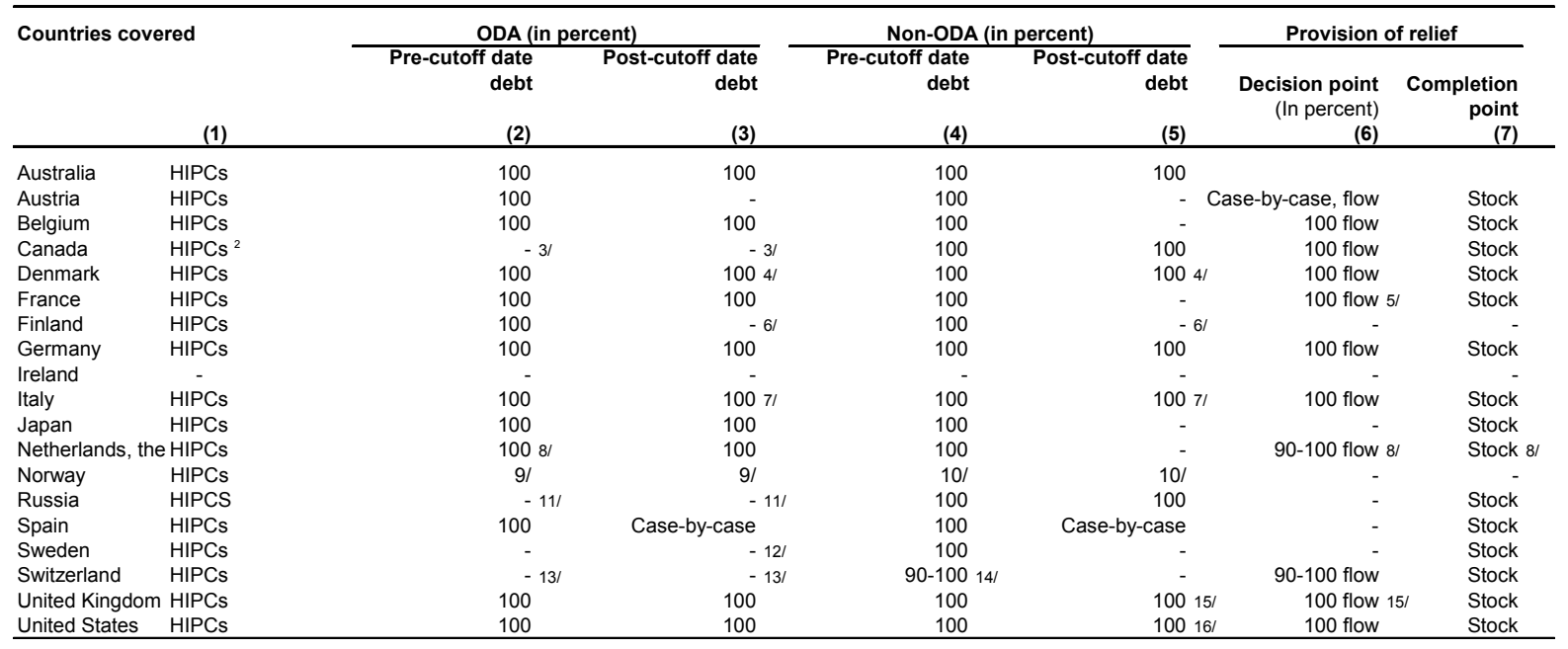

Source: Paris Club Secretariat.

${ }^{1}$ Columns (1) to (7) describe the additional debt relief provided following a specific methodology under bilateral initiatives and need to be read as a whole for each creditor In column (1), "HIPCs" stands for eligible countries effectively qualifying for the HIPC process. A "100 percent" mention in the table indicates that the debt relief provided under the enhanced HIPC Initiative framework will be topped up to 100 percent through a bilateral initiative.

${ }^{2}$ Canada: including Bangladesh. Canada has granted a moratorium of debt service as of January 2001 on all debt disbursed before end-March 1999 for 13 out of 17 HIPI with debt service due to Canada. Eligible countries are Benin, Bolivia, Cameroon, Dem. Rep. Of Congo, Ethiopia, Ghana, Guyana, Honduras, Madagascar, Rwanda, Sen Tanzania, and Zambia. $100 \%$ cancellation will be granted at completion point. As of July 2004, Canada has provided completion point stock of debt cancellation for Benin, Bolivia, Guyana, Senegal and Tanzania.

${ }^{3} 100$ percent of ODA claims have already been cancelled on HIPCs, with the exception of Myanmar's debt to Canada.

${ }^{4}$ Denmark provides 100 percent cancellation of ODA loans and non-ODA credits contracted and disbursed before September 27,1999

${ }^{5}$ France: cancellation of 100 percent of debt service on pre-cutoff date commercial claims on the government as they fall due starting at the decision point. Once countries have reached their completion point, debt relief on ODA claims on the government will go to a special account and will be used for specific development projects ${ }^{6}$ Finland: no post-COD claims

${ }^{7}$ Italy: cancellation of 100 percent of all debts (pre- and post-cutoff date, ODA and non-ODA) incurred before June 20, 1999 (the Cologne Summit). At decision point, cancellation of the related amounts falling due in the interim period. At completion point, cancellation of the stock of remaining debt.

${ }^{8}$ The Netherlands: 100 percent ODA (pre- and post-cutoff date debt will be cancelled at decision point); for non-ODA: in some particular cases (Benin, Bolivia, Burkina Faso, Ethiopia, Ghana, Mali, Mozambique, Nicaragua, Rwanda, Tanzania, Uganda and Zambia), the Netherlands will write off 100 percent of the consolidated am on the flow at decision point; all other HIPCs will receive interim relief up to 90 percent reduction of the consolidated amounts. At completion point, all HIPCs will receive 100 per cent cancellation of the remaining stock of the pre-cutoff date debt.

${ }^{9}$ Norway has cancelled all ODA claims.

${ }^{10}$ Due to the current World Bank/IMF methodology for recalculating debt reduction needs at HIPC completion point, Norway has postponed the decisions on whether or not to grant $100 \%$ debt reduction until after the completion point.

${ }^{11}$ Russia has no ODA claims

${ }^{12}$ Sweden has no ODA claims.

${ }^{13}$ Switzerland has cancelled all ODA claims

${ }^{14}$ In some particular cases (Central African Republic, Liberia, Republic of Congo, Sierra Leone, Togo), Switzerland will write off 100 percent of the remaining debt stock at completion point; all other HIPCs will receive debt relief according to Paris Club terms.

${ }^{15}$ United Kingdom: "beyond 100 percent" full write-off of all debts of HIPCs as of their decision points, and reimbursement at the decision point of any debt service paid before the decision point.

${ }^{16}$ United States: 100 percent post-cutoff date non-ODA treated on debt assumed prior to June 20, 1999 (the Cologne Summit). 
Table 13. HIPC Initiative: Status of Country Cases Considered Under the Initiative, June 30, 2009

\begin{tabular}{|c|c|c|c|c|c|c|c|c|c|c|c|}
\hline \multirow{4}{*}{ Country } & \multirow{4}{*}{$\begin{array}{r}\text { Decision } \\
\text { Point }\end{array}$} & \multirow{4}{*}{$\begin{array}{r}\text { Completion } \\
\text { Point }\end{array}$} & \multicolumn{2}{|c|}{$\begin{array}{c}\text { Target } \\
\text { NPV of Debt-to- }\end{array}$} & \multicolumn{5}{|c|}{$\begin{array}{c}\text { Assistance Levels } \\
\text { (In millions of U.S. dollars, present value) }\end{array}$} & \multirow{4}{*}{$\begin{array}{r}\text { Percentage } \\
\text { Reduction } \\
\text { in NPV of } \\
\text { Debt }^{2} \\
\end{array}$} & \multirow{4}{*}{$\begin{array}{r}\text { Estimated Total } \\
\text { Nominal Debt } \\
\text { Service Relief } \\
\text { (In millions of } \\
\text { U.S. dollars) }\end{array}$} \\
\hline & & & \multirow{3}{*}{\multicolumn{2}{|c|}{$\begin{array}{cr}\text { Gov. } \\
\text { Exports } & \begin{array}{r}\text { revenue } \\
\text { (in percent) }\end{array} \\
\end{array}$}} & \multirow{3}{*}{\multicolumn{2}{|c|}{$\begin{array}{l}\text { Bilateral and } \\
\text { Total commercial }\end{array}$}} & \multirow{2}{*}{\multicolumn{3}{|c|}{ Multilateral }} & & \\
\hline & & & & & & & & & & & \\
\hline & & & & & & & Total & $\mathrm{IMF}^{3}$ & World Bank & & \\
\hline \multicolumn{12}{|c|}{ Completion point reached under enhanced framework (26) } \\
\hline Benin & Jul. 00 & Mar. 03 & 150 & & 265 & 77 & 189 & 24 & 84 & 31 & 460 \\
\hline Bolivia & & & & & 1,302 & 425 & 876 & 84 & 194 & & 2,060 \\
\hline original framework & Sep. 97 & Sep. 98 & 225 & & 448 & 157 & 291 & 29 & 54 & 14 & 760 \\
\hline enhanced framework & Feb. 00 & Jun. 01 & 150 & & 854 & 268 & 585 & 55 & 140 & 30 & 1,300 \\
\hline Burkina Faso & & & & & 553 & 83 & 469 & 57 & 231 & & 930 \\
\hline original framework & Sep. 97 & Jul. 00 & 205 & & 229 & 32 & 196 & 22 & 91 & 27 & 400 \\
\hline enhanced framework & Jul. 00 & Apr. 02 & 150 & & 195 & 35 & 161 & 22 & 79 & 30 & 300 \\
\hline topping-up & & Apr. 02 & 150 & & 129 & 16 & 112 & 14 & 61 & 24 & 230 \\
\hline Burundi & Aug. 05 & Jan. 09 & 150 & & 833 & 127 & 706 & 28 & 425 & 92 & 1,366 \\
\hline Cameroon & Oct. 00 & Apr. 06 & 150 & & 1,267 & 879 & 322 & 37 & 176 & 27 & 4,917 \\
\hline Central African Rep. & Sept. 07 & Jun. 09 & 150 & & 578 & 186 & 362 & 27 & 207 & 68 & 804 \\
\hline Ethiopia & & & & & 1,982 & 637 & 1,315 & 60 & 832 & & 3,275 \\
\hline enhanced framework & Nov. 01 & Apr. 04 & 150 & & 1,275 & 482 & 763 & 34 & 463 & 47 & 1,941 \\
\hline topping-up & & Apr. 04 & 150 & & 707 & 155 & 552 & 26 & 369 & 31 & 1,334 \\
\hline Gambia, The & Dec. 00 & Dec. 07 & 150 & & 67 & 17 & 49 & 2 & 22 & 27 & 112 \\
\hline Ghana & Feb. 02 & Jul. 04 & 144 & 250 & 2,186 & 1,084 & 1,102 & 112 & 781 & 56 & 3,500 \\
\hline original framework & Dec. 97 & May 99 & 107 & 280 & 256 & 91 & 165 & 35 & 27 & 24 & 634 \\
\hline enhanced framework & Nov. 00 & Dec. 03 & 150 & 250 & 335 & 132 & 202 & 40 & 41 & 40 & 719 \\
\hline Haiti & Nov. 06 & Jun. 09 & 150 & & 140 & 20 & 120 & 3 & 53 & 15 & 213 \\
\hline Honduras & Jul. 00 & Mar. 05 & 110 & 250 & 556 & 215 & 340 & 30 & 98 & 18 & 1,000 \\
\hline Madagascar & Dec. 00 & Oct. 04 & 150 & & 836 & 474 & 362 & 19 & 252 & 40 & 1,900 \\
\hline Malawi & & & & & 1,057 & 171 & 886 & 45 & 622 & & 1,628 \\
\hline enhanced framework & Dec. 00 & Aug. 06 & 150 & & 646 & 164 & 482 & 30 & 333 & 44 & 1,025 \\
\hline topping-up & $\ldots$ & Aug. 06 & 150 & & 411 & 7 & 404 & 15 & 289 & 35 & 603 \\
\hline Mali & & & & & 539 & 169 & 370 & 59 & 185 & & 895 \\
\hline original framework & Sep. 98 & Sep. 00 & 200 & & 121 & 37 & 84 & 14 & 43 & 9 & 220 \\
\hline enhanced framework & Sep. 00 & Mar. 03 & 150 & & 417 & 132 & 285 & 45 & 143 & 29 & 675 \\
\hline Mauritania & Feb. 00 & Jun. 02 & 137 & 250 & 622 & 261 & 361 & 47 & 100 & 50 & 1,100 \\
\hline Mozambique & & & & & 2,023 & 1,270 & 753 & 143 & 443 & & 4,300 \\
\hline original framework & Apr. 98 & Jun. 99 & 200 & & 1,717 & 1,076 & 641 & 125 & 381 & 63 & 3,700 \\
\hline enhanced framework & Apr. 00 & Sep. 01 & 150 & & 306 & 194 & 112 & 18 & 62 & 27 & 600 \\
\hline Nicaragua & Dec. 00 & Jan. 04 & 150 & & 3,308 & 2,175 & 1,134 & 82 & 191 & 73 & 4,500 \\
\hline Niger & & & & & 663 & 235 & 428 & 42 & 240 & & 1,190 \\
\hline enhanced framework & Dec. 00 & Apr. 04 & 150 & & 521 & 211 & 309 & 28 & 170 & 53 & 944 \\
\hline topping-up & $\ldots$ & Apr. 04 & 150 & & 143 & 23 & 119 & 14 & 70 & 25 & 246 \\
\hline Rwanda & & & & & 696 & 65 & 631 & 63 & 383 & & 1,316 \\
\hline enhanced framework & Dec. 00 & Apr. 05 & 150 & & 452 & 56 & 397 & 44 & 228 & 71 & 839 \\
\hline topping-up & & Mar. 07 & 150 & & 25 & 2 & 23 & 1 & 23 & 45 & 49 \\
\hline Senegal & Jun. 00 & Apr. 04 & 133 & 250 & 488 & 212 & 276 & 45 & 124 & 19 & 850 \\
\hline Sierra Leone & Mar. 02 & Dec. 06 & 150 & & 675 & 335 & 340 & 125 & 123 & 81 & 994 \\
\hline Tanzania & Apr. 00 & Nov. 01 & 150 & & 2,026 & 1,006 & 1,020 & 120 & 695 & 54 & 3,000 \\
\hline Uganda & & & & & 1,003 & 183 & 820 & 160 & 517 & & 1,950 \\
\hline original framework & Apr. 97 & Apr. 98 & 202 & & 347 & 73 & 274 & 69 & 160 & 20 & 650 \\
\hline enhanced framework & Feb. 00 & May 00 & 150 & & 656 & 110 & 546 & 91 & 357 & 37 & 1,300 \\
\hline Zambia & Dec. 00 & Apr. 05 & 150 & & 2,499 & 1,168 & 1,331 & 602 & 493 & 63 & 3,900 \\
\hline Decision point reached under er & ed framewo & & & & & & & & & & \\
\hline Afghanistan & Jul. 07 & Floating & 150 & & 571 & 436 & 135 & 0 & 75 & 51 & 1,272 \\
\hline Chad & May. 01 & Floating & 150 & & 170 & 35 & 134 & 18 & 68 & 30 & 260 \\
\hline Cote d'Ivoire & Mar. 09 & Floating & & 250 & 3,005 & 2,311 & 694 & 38 & 402 & 24 & 3,129 \\
\hline Congo, Democratic Rep. of & Jul. 03 & Floating & 150 & & 6,311 & 3,837 & 2,474 & 472 & 831 & 80 & 10,389 \\
\hline Congo Rep. of & Mar. 06 & Floating & & 250 & 1,679 & 1,561 & 118 & 8 & 49 & 32 & 2,881 \\
\hline Guinea & Dec. 00 & Floating & 150 & & 545 & 215 & 328 & 31 & 152 & 32 & 800 \\
\hline Guinea-Bissau & Dec. 00 & Floating & 150 & & 416 & 212 & 204 & 12 & 93 & 85 & 790 \\
\hline Liberia & Mar. 08 & Floating & 150 & & 2,846 & 1,420 & 1,426 & 732 & 375 & 91 & 4,008 \\
\hline $\begin{array}{l}\text { Togo } \\
\text { Total assistance provided/cor }\end{array}$ & ed Nov. 08 & Floating & & 250 & $\begin{array}{r}270 \\
42,690\end{array}$ & $\begin{array}{r}120 \\
21,876\end{array}$ & $\begin{array}{r}150 \\
20,686\end{array}$ & $\begin{array}{r}0 \\
3,407\end{array}$ & $\begin{array}{r}98 \\
9,729\end{array}$ & 19 & $\begin{array}{r}360 \\
71,664\end{array}$ \\
\hline
\end{tabular}

Sources: IMF and World Bank Board decisions, completion point documents, decision point documents, preliminary HIPC documents, and staff calculations. Assistance levels are at countries' respective decision or completion points, as applicable.

${ }^{2}$ In percent of the net present value of debt at the decision or completion point (as applicable), after the full use of traditional debt-relief mechanisms.

${ }^{3}$ Equivalent to SDR 1,698 million at an SDR/USD exchange rate of 0.644524, as of October 4, 2007. 


\section{APpendix I. Republic OF Congo: DebT MANAgEMENT}

1. Debt management in Congo has improved since the decision point was reached in 2006, particularly with respect to debt recording and reporting. Two such issues have also been included as the basis for HIPC completion point triggers (see text Box 1). As several issues remain to be addressed, the authorities have actively sought additional support from the World Bank and other partners in developing a detailed technical assistance and capacity building program to support further reforms and improvements. A technical assistance mission led by the Bank's treasury department has recently conducted an in-depth assessment of capacity building needs.

2. In Congo, debt management functions are undertaken by the Caisse Congolaise d'Amortissement (CCA), which is a quasi-independent agency responsible for undertaking new borrowing on behalf of the central government, and managing debt data and repayments. The CCA's mandate includes responsibilities like the development of debt management strategies, participation in the negotiation of new loans, and analytical functions related to the assessment of the potential costs and risks of new borrowing.

\section{In the area of debt recording, the CCA has completed the installation of the} UNCTAD Debt Management and Financial Analysis system (DMFAS). This system allows the authorities to record and monitor public external debt and on-lending operations. It provides detailed real-time information regarding loans and rates, which allow the CCA to make projections regarding debt service payments and coordinate with the Treasury and the Budget Directorate for the purposes of budget preparation and cash management. The staff of the CCA has received extensive training from UNCTAD in the use of the software.

4. Debt reporting by the government has improved since the decision point. In line with the completion point trigger on debt management, the CCA provides the Ministry of Finance with the data required to produce and publish on the Ministry's website quarterly reports regarding external debt stock, arrears, and quarterly flows. ${ }^{1}$ It is envisioned that this practice will continue in the future.

5. However, capacity constraints and procedural deficiencies have prevented the agency from undertaking many of these functions on a regular basis. A recent serious mistake in reporting on the terms of settlement with litigating creditors at end-2008 to the Paris Club illustrates these remaining capacity challenges. In a first communication to the Paris Club, the authorities indicated an incorrect discount factor of 79 percent for the terms of the settlement. The error was detected during the Bank-Fund debt data reconciliation exercise for HIPC, upon which the authorities correct the discount factor to 37 percent. The error was attributed to the inclusion of some debts covered by the London Club agreement as part of claims held by litigating creditors.

\footnotetext{
${ }^{1}$ http://www.mefb-cg.net/dette ie/dette interieure.html
} 
6. To avoid such mistakes in the future, the authorities have identified a number of key measures to further strengthen debt management capacity in the CCA and beyond. These include measures aimed at developing new procedures on producing annual debt management strategies, mechanisms for coordination between the CCA, the Ministry of Finance, and the regional monetary authorities for the purpose of treasury management and macroeconomic forecasting, debt data security and auditing procedures, as well as the analysis of costs and risks of potential new borrowing. The CCA is closely collaborating with technical assistance providers, most notably the World Bank to implement these measures. 


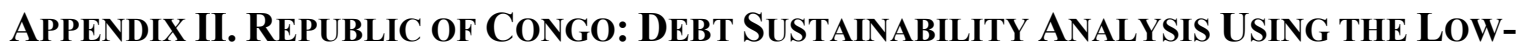 INCOME COUNTRY FRAMEWORK}

Based on the joint IMF-World Bank debt sustainability framework for low-income countries (LICs), the risk of debt distress for Congo will be moderate. This is due to presumed debt relief under the enhanced HIPC Initiative, under which Congo's external and public debt burden indicators will improve significantly. Only under the most extreme scenario, would the debt indicators breach the relevant thresholds. ${ }^{2}$

\section{BACKGROUND}

1. The LIC DSA differs from the HIPC DSA in four main ways: (i) the discount rate for the LIC DSA is fixed at 4 percent, compared to the currency-specific 6-month averages of commercial interest reference rates for the HIPC DSA; (ii) the LIC DSA uses WEO exchange rate projections instead of the actual exchange rates at end-2008 used for the HIPC DSA; and (iii) exports used for various debt distress indicators in the LIC version are the latest annual projections rather than the three-year backward-looking average, and (iv) in the sensitivity analysis, the LIC DSA assumes that additional financing needs in the face of shocks are filled by new borrowing, while the HIPC DSA assumes that additional financing needs are provided from the accumulated oil wealth with no new borrowing.

2. This DSA is based on the stock of debt at the end of 2008. The previous full DSA, carried out during the 2008 Article IV consultation in November 2008, was based on the stock of debt at the end of 2007 and concluded that Congo's debt distress remained high. ${ }^{3}$

3. It is estimated that at the end of 2008 , total public debt including arrears was US\$ 6.6 billion-66 percent of GDP—down from the peak of US\$ 12 billion in 2004. External debt amounted to US\$ 5.6 billion, 57 percent of GDP, of which Paris Club creditors accounted for about 61 percent, followed by non-London Club commercial creditors and non-Paris Club bilateral creditors at 13 percent and 10 percent, respectively. Domestic debt is relatively small, about 10 percent of GDP, and mostly consists of arrears of wages, pensions, and liabilities to public enterprises.

4. Debt relief thus far substantially reduced external arrears, but they still stood at US\$ 939 million at the end of 2008; domestic arrears were US\$ 965 million. Congo has made significant progress in pursuing debt relief across the board and reduced external arrears by 69 percent in 2004-08. The country has (i) concluded debt restructurings with the Paris Club in 2004, 2006, and 2008; (ii) obtained debt relief from London Club creditors in

\footnotetext{
${ }^{2}$ The three-year average of the CPIA index of Congo in 2006-2008 is 2.73. According to the LIC DSF, Congo is classified as a weak performer.

${ }^{3}$ See IMF document Country Report No. 09/74.
} 
2007; (iii) settled a long-standing dispute with litigating creditors holding court-validated claims in 2008; and (iv) received debt reduction from various non-Paris Club bilateral creditors and non-London Club commercial creditors, mostly on HIPC-comparable terms. The remaining external arrears are with non-London Club commercial creditors, mainly suppliers (US\$ 694 million, or 73 percent of total external arrears) and non-Paris Club bilateral creditors (US\$ 245 million, or 26 percent). The government has also cut domestic arrears in half since 2004.

\section{UNDERLYING DSA ASSUMPTIONS}

\section{This LIC DSA incorporates four revisions to the previous DSA:}

- $\quad$ Global economic projections were aligned with the latest World Economic Outlook (WEO), although in both the current and the previous DSA the average oil price in 2009-14 was about the same at around US\$ 78 per barrel.

- The macroeconomic assumptions for Congo were revised as outlined in Box 2 (main text). Because of the global downturn, average real non-oil sector growth in 2009-14 was lowered from the previous 7.3 percent to 6.0 percent. Average real oil sector growth in the same period was raised from the previous 0.4 percent to 4.6 percent, mainly due to the prospects of new oil production from new fields. ${ }^{4,5}$ Major changes have also been made with regard to some components of the balance payments, reflecting the revisions in the authorities' data.

- $\quad$ This DSA uses the latest debt database, reconciled for the HIPC completion point DSA. Debt service projections were revised incorporating the full delivery of HIPC/MDRI debt relief expected at the completion point.

- $\quad$ The external borrowing assumption was revised incorporating newly contracted and prospective loans as described below.

\section{New external borrowing is in line with the PRGF concessionality requirement} until 2019 (minimum grant element of at least 50 percent). It is assumed that over the projection period Congo will receive loans from the French Development Agency (AFD), Arab Bank for Economic and Development in Africa (BADEA), China and the World Bank. Total loan from the AFD amounts to $€ 29$ million, which is projected to be disbursed in $2009 .{ }^{6}$

\footnotetext{
${ }^{4}$ However, assumptions on future oil production remain conservative.

${ }^{5}$ For example, FDI was revised upward by more accurately recording reinvestment of profits by oil companies and imports were revised downward by more accurately capturing oil sector-related goods and services.

${ }^{6}$ The loan is for the Port Authority of Pointe Noire to finance the rehabilitation of the port's facilities. This loan, which precludes any loan guarantee from the government of Congo, forms part of a non-concessional external financing package amount to $€ 67.1$ million. The other creditors include the European Investment Bank (EIB)
} (continued) 
Total from the BADEA amounts to US\$ 10 million, which is assumed to be disbursed in the period of 2010-13. Total Chinese lending is equivalent to US\$ 1.6 billion, which is assumed to be disbursed until 2015 in line with the contract signed in 2008. IDA financing is on "hardened" terms since Congo passed the IDA-only income threshold in 2007. Disbursement is expected to start with US\$ 9 million in 2010 and US\$ 18 million in 2011, and to increase gradually thereafter. Lending terms for both the Chinese and IDA "hardened" loans meet the PRGF concessionality requirement. However, Congo is expected to graduate to IBRD status in 2019 and start borrowing from the IBRD thereafter.

7. It is assumed that all external and domestic arrears remaining will be cleared by 2014 through repayment, cancellation and rescheduling. Congo is committed to continuing its efforts to obtain HIPC-comparable debt relief from its remaining external creditors. It is therefore assumed that roughly a half of external arrears will be cancelled in 2010 , and the rest rescheduled for repayment on various terms. Domestic arrears are projected to be repaid by 2014 , which is incorporated in the government's budget planning.

8. As in the previous DSA, the external DSA is run on a gross basis and the public DSA is run on a net basis in order to examine the impact of oil wealth on debt indicators. Net debt is defined as debt less liquid financial assets. For Congo, liquid financial assets are government deposits at the regional central bank, which mostly consist of oil savings.

\section{EXternal DebT SuStainabiLITY ANALYSIS}

9. In the baseline scenario, all debt indicators remain below the threshold for the entire projection period after the HIPC completion point (Figure 1). Furthermore, despite the projected declining concessionality of new loans and lower oil revenues, all debt indicators trend downward as the size of new borrowing remains relatively small.

\section{The historical scenario appears less favorable than the baseline scenario in the} medium term but more favorable in the long term. In the historical scenario, most debt indicators stay above the baseline scenario until about 2020 because projected oil production, and therefore revenues and exports in the baseline scenario, is much higher than the historical level. In the long run, the situation reverses, and in the historical scenario most debt indicators stay below the baseline scenario. ${ }^{7}$

(€29 million) and the Central African States Development Bank (CASDB) (€9.1 million). Since subsequent loans from the EIB and CASDB have not formally contracted, this LIC DSA includes only the loan from the AFD. The Board on the first review under the PRGF provided a waiver for the non-concessionality of the AFD loan.

${ }^{7}$ The historical scenario shows negative debt ratios over the projection period because oil production under the historical scenario is higher than the baseline after 2020. Under the design of the DSA template, the additional

(continued) 
11. Stress tests indicate Congo is still vulnerable to external shocks. In the most extreme tests, most of debt indicators cross or stay above the threshold. Given its high dependency on the oil sector, Congo is very sensitive to changes in world commodity prices. This result is significantly different from that in the HIPC DSA because of different assumptions on new borrowing as described above.

\section{Public Debt Sustainability Analysis}

12. The public DSA on a net basis paints a very different picture from the external DSA on a gross basis owing to Congo's oil wealth. Most debt indicators for the public DSA on a net basis turn negative as oil savings accumulate rapidly over time (Figure 2). On a gross basis, however, the picture for public DSA is similar to that for external DSA because domestic debt will shrink to less than 0.3 percent of GDP by 2014 , once the government pays back all domestic arrears.

\section{Stress tests for public DSA on a net basis do not suggest any vulnerability.} Rapidly growing oil savings will be a strong buffer against shocks.

\section{CONCLusions}

\section{Congo should be considered at moderate risk of debt distress based on the} results of the external DSA. The external DSA shows that in the baseline scenario debt indicators remain below the policy dependent thresholds, but increase when the country faces shocks. It is important that the government continues to strengthen debt management and maintain a conservative borrowing policy. At the same time, the government's commitment to maintain fiscal discipline and increase non-oil revenue, together with structural reform in key areas, would help to safeguard long-term debt sustainability.

oil revenue is used to pay back debt and once it is expunged, oil wealth accumulates (i.e., shown in the figure as negative debt). 
Figure 1. Republic of Congo: Indicators of Public and Publicly Guaranteed External Debt Under Alternative Scenarios, 2009-29 1/
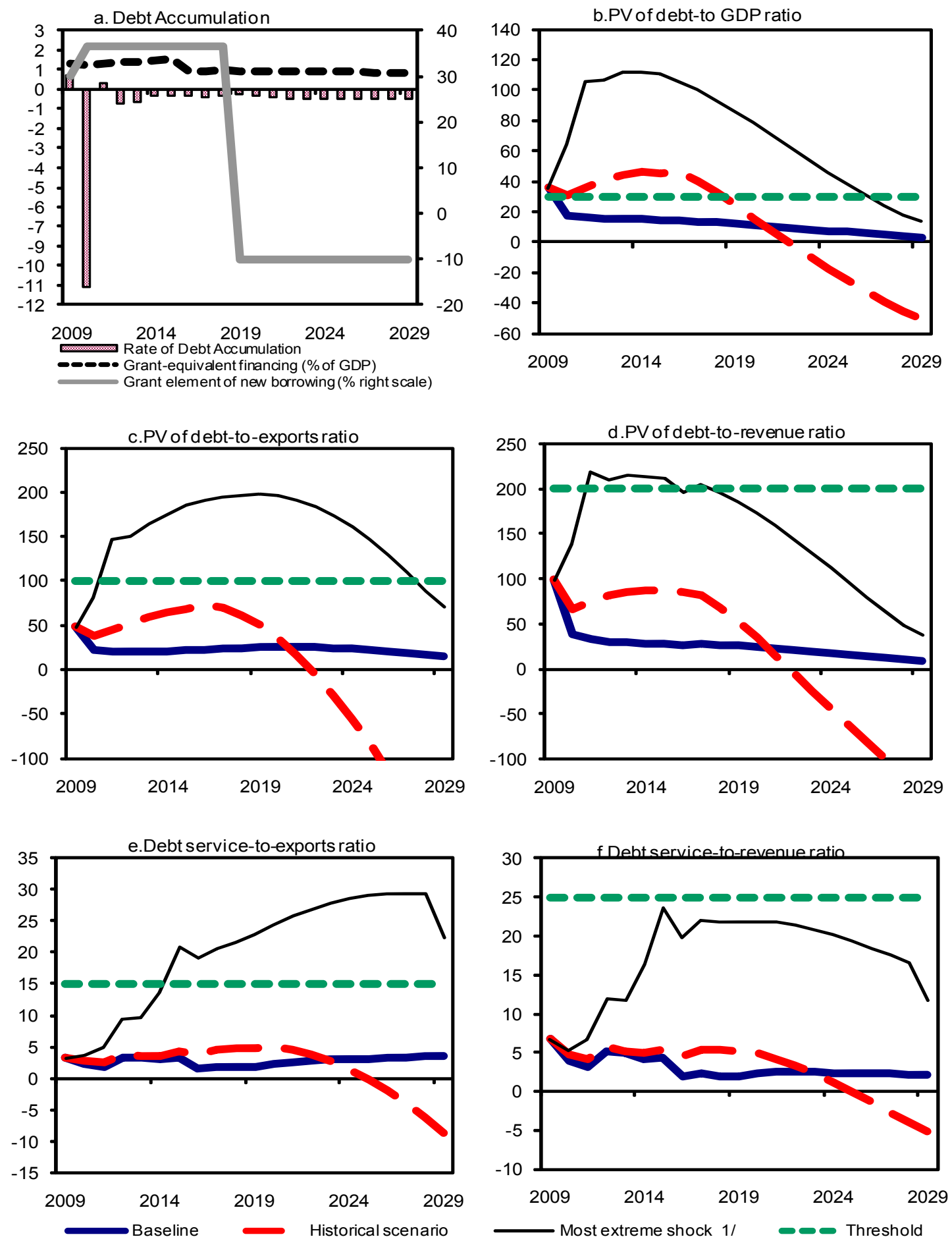

Sources: Congolese authorities; and World Bank and Fund staff estimates and projections. $1 /$ The most extreme stress test is the test that yields the highest ratio in 2019. In figure $\mathrm{b}$. it corresponds to a Combination shock; in c. to a Exports shock; in d. to a Combination shock; in e. to a Exports shock and in picture $\mathrm{f}$. to a Combination shock 
Figure 2. Republic of Congo: Indicators of Public Debt Under Alternative Scenarios, 2009-29
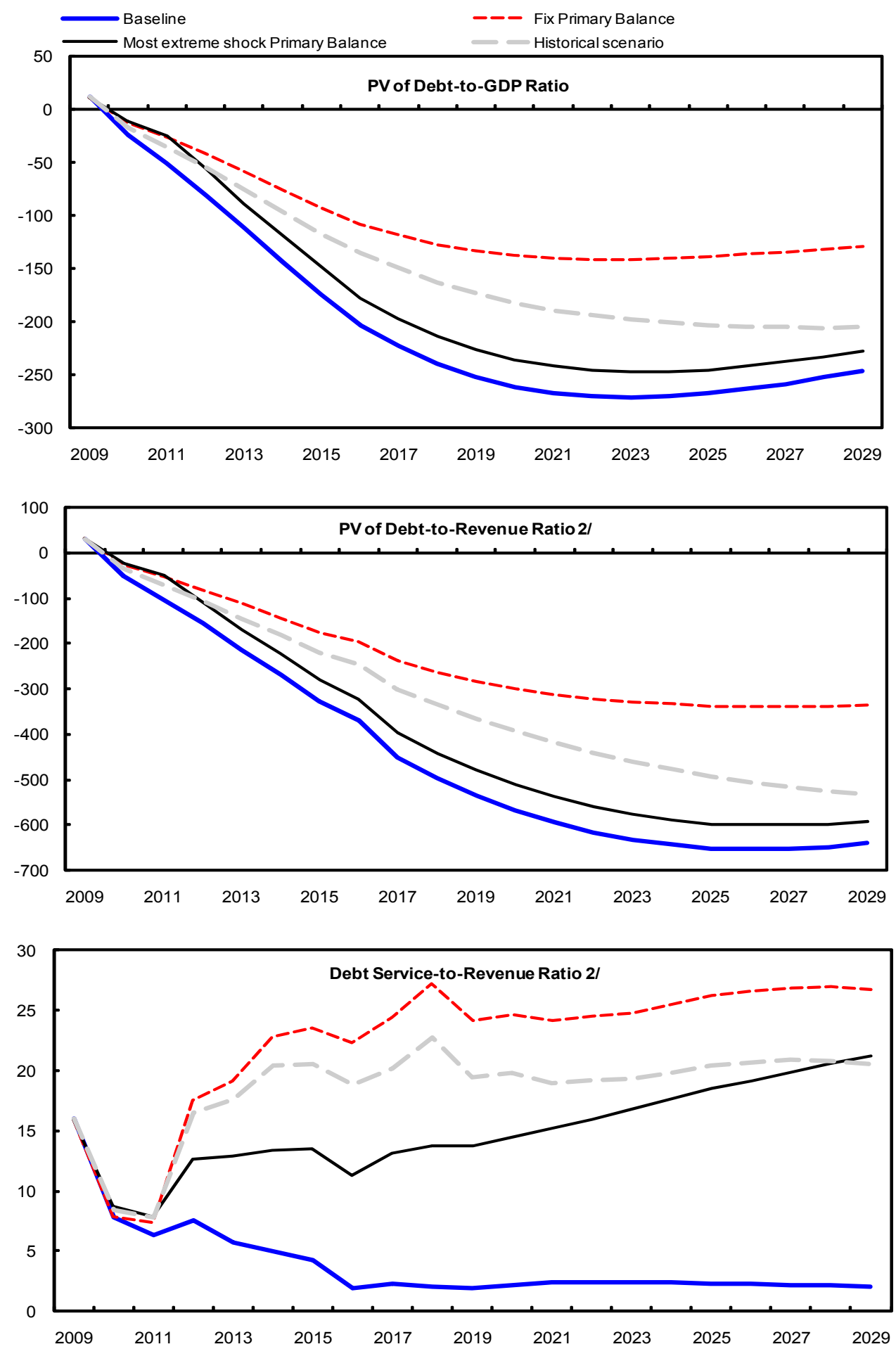

Sources: Congolese authorities; and World Bank and Fund staff estimates and projections. 1/ The most extreme stress test is the test that yields the highest ratio in 2019.

2/ Revenues are defined inclusive of grants. 
Table 1. Republic of Congo: External Debt Sustainability Framework, Baseline Scenario, 2006-29

(In percent of GDP, unless otherwise indicated)

\begin{tabular}{|c|c|c|c|c|c|c|c|c|c|c|c|}
\hline & \multicolumn{3}{|c|}{ Actual } & \multicolumn{6}{|c|}{ Projections } & \multirow[b]{2}{*}{2019} & \multirow[b]{2}{*}{2029} \\
\hline & 2006 & 2007 & 2008 & 2009 & 2010 & 2011 & 2012 & 2013 & 2014 & & \\
\hline External debt (nominal) $1 /$ & 81.6 & 90.9 & 56.6 & 67.7 & 20.2 & 19.2 & 18.5 & 18.6 & 18.7 & 14.8 & 3.4 \\
\hline $\mathrm{o} / \mathrm{w}$ public and publicly guaranteed (PPG) & 81.6 & 90.9 & 56.6 & 67.7 & 20.2 & 19.2 & 18.5 & 18.6 & 18.7 & 14.8 & 3.4 \\
\hline Change in external debt & -26.7 & 9.3 & -34.2 & 11.1 & -47.5 & -1.0 & -0.6 & 0.1 & 0.1 & -1.1 & -0.8 \\
\hline Identified net debt-creating flows & -48.8 & -17.9 & -48.1 & -13.2 & -30.2 & -30.3 & -31.2 & -29.3 & -28.5 & -17.2 & -5.8 \\
\hline Non-interest current account deficit & -5.2 & $\mathbf{7 . 0}$ & -0.1 & 13.7 & -2.4 & -5.3 & -6.9 & -5.3 & -4.3 & 6.5 & 17.8 \\
\hline Deficit in balance of goods and services & -36.0 & -25.0 & -27.2 & -17.3 & -30.8 & -33.3 & -31.4 & -26.5 & -22.0 & 0.9 & 21.1 \\
\hline Exports & 85.3 & 83.4 & 78.6 & 74.3 & 80.2 & 80.8 & 79.0 & 75.4 & 71.8 & 48.8 & 22.6 \\
\hline Imports & 49.4 & 58.4 & 51.4 & 57.0 & 49.4 & 47.5 & 47.6 & 48.9 & 49.8 & 49.7 & 43.7 \\
\hline Net current transfers (negative $=$ inflow) & 0.5 & 0.4 & 0.3 & 0.3 & 0.0 & -0.1 & -0.1 & -0.1 & -0.1 & 0.0 & 0.2 \\
\hline o/w official & 0.0 & -0.3 & -0.3 & -0.4 & -0.5 & -0.6 & -0.7 & -0.7 & -0.8 & -0.9 & -0.9 \\
\hline Other current account flows (negative $=$ net inflow) & 30.3 & 31.6 & 26.9 & 30.7 & 28.4 & 28.2 & 24.6 & 21.3 & 17.7 & 5.5 & -3.5 \\
\hline Net FDI (negative $=$ inflow) & -24.5 & -28.0 & -23.2 & -22.7 & -22.5 & -24.3 & -24.2 & -24.1 & -24.0 & -23.2 & -23.5 \\
\hline Endogenous debt dynamics 21 & -19.1 & 3.1 & -24.8 & -4.2 & -5.3 & -0.7 & -0.1 & 0.2 & -0.2 & -0.5 & -0.1 \\
\hline Contribution from nominal interest rate & 3.9 & 2.2 & 1.5 & 1.2 & 0.6 & 0.5 & 0.4 & 0.4 & 0.3 & 0.1 & 0.1 \\
\hline Contribution from real GDP growth & -5.3 & 1.3 & -3.6 & -5.4 & -5.9 & -1.2 & -0.6 & -0.2 & -0.5 & -0.7 & -0.2 \\
\hline Contribution from price and exchange rate changes & -17.6 & -0.4 & -22.7 & & & & . & & & & \\
\hline Residual (3-4) 3/ & 22.1 & 27.2 & 13.9 & 24.3 & -17.3 & 29.2 & 30.6 & 29.3 & 28.6 & 16.1 & 5.0 \\
\hline o/w exceptional financing & -3.4 & -52.0 & -11.1 & 0.0 & -29.1 & 0.0 & 0.0 & 0.0 & 0.0 & 0.0 & 0.0 \\
\hline PV of external debt $4 /$ & $\ldots$ & $\ldots$ & 27.5 & 35.4 & 17.6 & 16.3 & 15.3 & 15.0 & 14.8 & 12.1 & 3.4 \\
\hline In percent of exports & $\ldots$ & $\ldots$ & 34.9 & 47.7 & 22.0 & 20.2 & 19.4 & 19.9 & 20.6 & 24.8 & 15.0 \\
\hline PV of PPG external debt & $\ldots$ & $\ldots$ & 27.5 & 35.4 & 17.6 & 16.3 & 15.3 & 15.0 & 14.8 & 12.1 & $\mathbf{3 . 4}$ \\
\hline In percent of exports & $\ldots$ & $\ldots$ & 34.9 & 47.7 & 22.0 & 20.2 & 19.4 & 19.9 & 20.6 & 24.8 & 15.0 \\
\hline In percent of government revenues & $\cdots$ & $\cdots$ & 53.6 & $\mathbf{9 9 . 0}$ & 37.7 & 33.7 & 30.3 & 29.1 & 28.2 & 26.2 & 9.0 \\
\hline Debt service-to-exports ratio (in percent) & 13.2 & 10.5 & 5.4 & 3.3 & 2.3 & 1.9 & 3.3 & 3.4 & 3.0 & 1.9 & 3.5 \\
\hline PPG debt service-to-exports ratio (in percent) & 13.2 & 10.5 & 5.4 & 3.3 & 2.3 & 1.9 & $\mathbf{3 . 3}$ & 3.4 & 3.0 & 1.9 & 3.5 \\
\hline PPG debt service-to-revenue ratio (in percent) & 25.3 & 20.6 & $\mathbf{8 . 3}$ & 6.8 & 4.0 & 3.2 & 5.2 & 4.9 & 4.2 & 2.0 & 2.1 \\
\hline Total gross financing need (Billions of U.S. dollars) & -1.4 & -0.9 & -2.0 & -0.6 & -2.8 & -3.7 & -3.8 & -3.5 & -3.4 & -2.2 & -1.2 \\
\hline Non-interest current account deficit that stabilizes debt ratio & 21.5 & -2.2 & 34.1 & 2.6 & 45.1 & -4.2 & -6.3 & -5.3 & -4.4 & 7.6 & 18.6 \\
\hline \multicolumn{12}{|l|}{ Key macroeconomic assumptions } \\
\hline Real GDP growth (in percent) & 6.2 & -1.6 & 5.6 & 7.6 & 12.1 & 6.6 & 2.9 & 1.1 & 2.5 & 4.3 & 4.8 \\
\hline GDP deflator in US dollar terms (change in percent) & 19.5 & 0.5 & 33.3 & -25.8 & 25.1 & 3.5 & -1.7 & -3.3 & -2.9 & -0.9 & 2.2 \\
\hline Effective interest rate (percent) 5/ & 4.5 & 2.7 & 2.3 & 1.6 & 1.2 & 2.8 & 2.3 & 1.9 & 1.5 & 0.9 & 2.1 \\
\hline Growth of exports of G\&S (US dollar terms, in percent) & 30.6 & -3.4 & 32.7 & -24.5 & 51.4 & 11.1 & -1.0 & -6.8 & -5.3 & -4.8 & 0.6 \\
\hline Growth of imports of G\&S (US dollar terms, in percent) & 34.3 & 17.0 & 23.8 & -11.4 & 21.5 & 6.1 & 1.5 & 0.3 & 1.4 & 3.2 & 5.7 \\
\hline Grant element of new public sector borrowing (in percent) & & & & 29.9 & 36.5 & 36.5 & 36.7 & 36.7 & 36.6 & -9.9 & -9.9 \\
\hline Government revenues (excluding grants, in percent of GDP) & 44.3 & 42.7 & 51.3 & 35.8 & 46.8 & 48.3 & 50.7 & 51.6 & 52.4 & 46.3 & 37.5 \\
\hline Aid flows (in Billions of US dollars) $7 /$ & 0.0 & 0.1 & 0.1 & 0.1 & 0.3 & 0.4 & 0.4 & 0.4 & 0.4 & 0.2 & 0.3 \\
\hline o/w Grants & 0.0 & 0.0 & 0.0 & 0.0 & 0.1 & 0.1 & 0.1 & 0.1 & 0.1 & 0.1 & 0.2 \\
\hline o/w Concessional loans & 0.0 & 0.0 & 0.0 & 0.0 & 0.2 & 0.3 & 0.3 & 0.3 & 0.3 & 0.0 & 0.0 \\
\hline Grant-equivalent financing (in percent of GDP) 8/ & $\ldots$ & $\ldots$ & $\ldots$ & 1.4 & 1.3 & 1.4 & 1.5 & 1.5 & 1.6 & 1.0 & 0.9 \\
\hline Grant-equivalent financing (in percent of external financing) 8/ & $\cdots$ & $\ldots$ & $\cdots$ & 40.6 & 51.2 & 53.5 & 54.3 & 54.8 & 55.4 & 82.4 & 82.4 \\
\hline \multirow{5}{*}{$\begin{array}{l}\text { Memorandum items: } \\
\text { Nominal GDP (Billions of US dollars) } \\
\text { Nominal dollar GDP growth } \\
\text { PV of PPG external debt (in Billions of US dollars) } \\
\text { (PVt-PVt-1)/GDPt-1 (in percent) }\end{array}$} & & & & & & & & & & & \\
\hline & 7.7 & 7.7 & 10.8 & 8.6 & 12.1 & 13.3 & 13.5 & 13.2 & 13.1 & 14.1 & 25.0 \\
\hline & 26.9 & -1.1 & 40.7 & -20.2 & 40.3 & 10.3 & 1.2 & -2.3 & -0.5 & 3.4 & 7.1 \\
\hline & & & 3.0 & 3.0 & 2.1 & 2.2 & 2.1 & 2.0 & 1.9 & 1.7 & 0.8 \\
\hline & & & & 0.8 & -10.7 & 0.4 & -0.8 & -0.7 & -0.3 & -0.2 & -0.5 \\
\hline
\end{tabular}

Sources: Congolese authorities; and World Bank and Fund staff estimates and projections.

$1 /$ On a gross basis. Includes only public sector external debt.

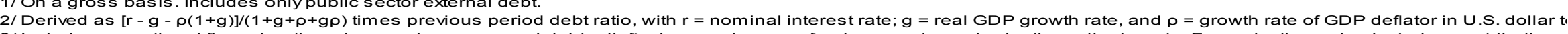

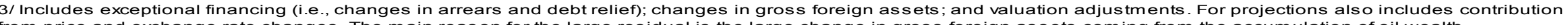
from price and exchange rate changes. The main reason for the large residual is the large change in gross foreign assets coming from the accumulation of oil wealth.

4/ Assumes that PV of private sector debt is equivalent to its face value.

$6 /$ Historical averages and standard deviations are generally derived over the past 10 years, subject to data availability.

6/ Historical averages and standard deviations are generaly

8 / Grant-equivalent financing includes grants provided directly to the government and through new borrowing (difference between the face value and the PV of new debt). 


\begin{tabular}{|c|c|c|c|c|c|c|c|c|c|c|c|}
\hline & \multicolumn{3}{|c|}{ Actual } & \multirow{2}{*}{$\frac{\text { Estimate }}{2009}$} & \multicolumn{7}{|c|}{ Projections } \\
\hline & 2006 & 2007 & 2008 & & 2010 & 2011 & 2012 & 2013 & 2014 & 2019 & 2029 \\
\hline Public sector debt $1 /$ & 84.3 & 81.8 & 43.6 & 44.7 & -21.7 & -47.9 & -77.4 & -108.8 & -139.3 & -249.9 & -245.9 \\
\hline $\mathrm{o} / \mathrm{w}$ foreign-currency denominated & 81.6 & 90.9 & 56.6 & 67.7 & 20.2 & 19.2 & 18.5 & 18.6 & 18.7 & 14.8 & 3.4 \\
\hline Change in public sector debt & -42.3 & -2.5 & -38.2 & 1.1 & -66.4 & -26.2 & -29.5 & -31.5 & -30.4 & -13.0 & 6.6 \\
\hline Identified debt-creating flows & -55.2 & -62.6 & -51.7 & -2.0 & -65.9 & -26.1 & -29.4 & -31.3 & -30.0 & -13.0 & 6.6 \\
\hline Primary deficit & -20.9 & -13.1 & -27.6 & -7.9 & -25.3 & -28.8 & -30.9 & -30.7 & -30.3 & -21.0 & -10.3 \\
\hline Revenue and grants & 44.4 & 43.1 & 51.6 & 36.3 & 47.4 & 49.1 & 51.4 & 52.4 & 53.2 & 47.2 & 38.4 \\
\hline of which: grants & 0.1 & 0.4 & 0.4 & 0.5 & 0.6 & 0.7 & 0.7 & 0.8 & 0.8 & 1.0 & 0.9 \\
\hline Primary (noninterest) expenditure & 23.5 & 30.0 & 24.0 & 28.5 & 22.1 & 20.3 & 20.5 & 21.6 & 22.9 & 26.2 & 28.1 \\
\hline Automatic debt dynamics & -30.8 & 2.5 & -13.0 & 5.9 & -11.5 & 2.7 & 1.5 & -0.5 & 0.3 & 8.0 & 16.9 \\
\hline Contribution from interest rate/growth differential & -8.3 & 1.5 & -2.7 & -6.4 & -1.7 & 3.1 & 0.9 & -1.6 & -0.5 & 7.9 & 16.9 \\
\hline of which: contribution from average real interest rate & -0.9 & 0.1 & 1.6 & -3.3 & 3.2 & 1.7 & -0.5 & -2.4 & -3.2 & -2.0 & 5.4 \\
\hline of which: contribution from real GDP growth & -7.4 & 1.4 & -4.3 & -3.1 & -4.8 & 1.3 & 1.4 & 0.9 & 2.6 & 9.8 & 11.6 \\
\hline Contribution from real exchange rate depreciation & -22.5 & 1.0 & -10.3 & 12.3 & -9.9 & -0.4 & 0.7 & 1.0 & 0.8 & & \\
\hline Other identified debt-creating flows & -3.4 & -52.1 & -11.1 & 0.0 & -29.1 & 0.0 & 0.0 & 0.0 & 0.0 & 0.0 & 0.0 \\
\hline Privatization receipts (negative) & 0.0 & -0.1 & 0.0 & 0.0 & 0.0 & 0.0 & 0.0 & 0.0 & 0.0 & 0.0 & 0.0 \\
\hline Recognition of implicit or contingent liabilities & 0.0 & 0.0 & 0.0 & 0.0 & 0.0 & 0.0 & 0.0 & 0.0 & 0.0 & 0.0 & 0.0 \\
\hline Debt relief (HIPC and other) & -3.4 & -52.0 & -11.1 & 0.0 & -29.1 & 0.0 & 0.0 & 0.0 & 0.0 & 0.0 & 0.0 \\
\hline Other (specify, e.g. bank recapitalization) & 0.0 & 0.0 & 0.0 & 0.0 & 0.0 & 0.0 & 0.0 & 0.0 & 0.0 & 0.0 & 0.0 \\
\hline Residual, including asset changes & 12.9 & 60.1 & 13.6 & 3.1 & -0.5 & -0.1 & -0.2 & -0.2 & -0.4 & 0.0 & 0.0 \\
\hline \multicolumn{12}{|l|}{ Other Sustainability Indicators } \\
\hline PV of public sector debt & 2.7 & -9.1 & 16.7 & 11.5 & -24.2 & -50.7 & -80.5 & -112.4 & -143.2 & -252.6 & -246.0 \\
\hline $\mathrm{o} / \mathrm{W}$ foreign-currency denominated & 0.0 & 0.0 & 29.7 & 34.5 & 17.7 & 16.4 & 15.4 & 15.1 & 14.8 & 12.1 & 3.4 \\
\hline o/w external & $\ldots$ & $\ldots$ & 29.7 & 34.5 & 17.7 & 16.4 & 15.4 & 15.1 & 14.8 & 12.1 & 3.4 \\
\hline PV of contingent liabilities (not included in public sector debt) & ... & $\ldots$ & $\ldots$ & $\ldots$ & & & $\ldots$ & & & & \\
\hline Gross financing need $2 /$ & -6.5 & -1.1 & -20.4 & -2.1 & -21.6 & -25.7 & -27.0 & -27.7 & -27.7 & -20.1 & -9.5 \\
\hline PV of public sector debt-to-revenue and grants ratio (in percent) & 6.1 & -21.0 & 32.3 & 31.6 & -51.2 & -103.3 & -156.6 & -214.5 & -269.1 & -534.8 & -640.5 \\
\hline PV of public sector debt-to-revenue ratio (in percent) & 6.1 & -21.2 & 32.5 & 32.1 & -51.8 & -104.8 & -158.9 & -217.8 & -273.4 & -546.2 & -655.9 \\
\hline o/w external 3/ & & & 57.9 & 96.3 & 37.7 & 33.8 & 30.4 & 29.3 & 28.2 & 26.2 & 9.0 \\
\hline Debt service-to-revenue and grants ratio (in percent) 4/ & 32.4 & 27.7 & 14.1 & 16.0 & 7.8 & 6.3 & 7.6 & 5.7 & 4.9 & 2.0 & 2.1 \\
\hline Debt service-to-revenue ratio (in percent) 4/ & 32.5 & 28.0 & 14.2 & 16.2 & 7.9 & 6.4 & 7.7 & 5.8 & 5.0 & 2.0 & 2.1 \\
\hline Primary deficit that stabilizes the debt-to-GDP ratio & 21.4 & -10.6 & 10.5 & -9.0 & 41.2 & -2.6 & -1.4 & 0.7 & 0.1 & -8.0 & -16.8 \\
\hline \multicolumn{12}{|l|}{ Key macroeconomic and fiscal assumptions } \\
\hline Real GDP growth (in percent) & 6.2 & -1.6 & 5.6 & 7.6 & 12.1 & 6.6 & 2.9 & 1.1 & 2.5 & 4.3 & 4.8 \\
\hline Average nominal interest rate on forex debt (in percent) & 4.5 & 2.7 & 2.3 & 1.6 & 1.2 & 2.8 & 2.3 & 1.9 & 1.5 & 0.9 & 2.1 \\
\hline Average real interest rate on domestic debt (in percent) & -12.6 & 11.1 & -16.8 & 27.8 & -16.6 & -3.8 & $\cdots$ & $\cdots$ & $\ldots$ & $\ldots$ & ... \\
\hline Real exchange rate depreciation (in percent, + indicates depreciat & -21.8 & 1.2 & -11.9 & 23.3 & & $\ldots$ & $\ldots$ & $\ldots$ & $\ldots$ & $\ldots$ & \\
\hline Inflation rate (GDP deflator, in percent) & 18.5 & -7.9 & 24.1 & -20.5 & 22.0 & 4.0 & -0.9 & -2.5 & -2.4 & -0.9 & 2.2 \\
\hline Growth of real primary spending (deflated by GDP deflator, in perc & 0.2 & 0.3 & -0.2 & 0.3 & -0.1 & 0.0 & 0.0 & 0.1 & 0.1 & 0.1 & 0.1 \\
\hline Grant element of new external borrowing (in percent) & $\ldots$ & $\ldots$ & $\ldots$ & 29.9 & 36.5 & 36.5 & 36.7 & 36.7 & 36.6 & -9.9 & -9.9 \\
\hline
\end{tabular}

Sources: Congolese authorities; and World Bank and Fund staff estimates and projections.

$1 /$ Covers the central government on a net basis. The large negative numbers show the accumulation of oil wealth.

$2 /$ Gross financing need is defined as the primary deficit plus debt service plus the stock of short-term debt at the end of the last period.

$3 /$ Revenues excluding grants.

4/ Debt service is defined as the sum of interest and amortization of medium and long-term debt.

5/ Historical averages and standard deviations are generally derived over the past 10 years, subject to data availability. 
Table 3. Republic of Congo: Sensitivity Analysis for Key Indicators of Public and Publicly Guaranteed External Debt, 2006-29 (In percent of GDP, unless otherwise indicated)

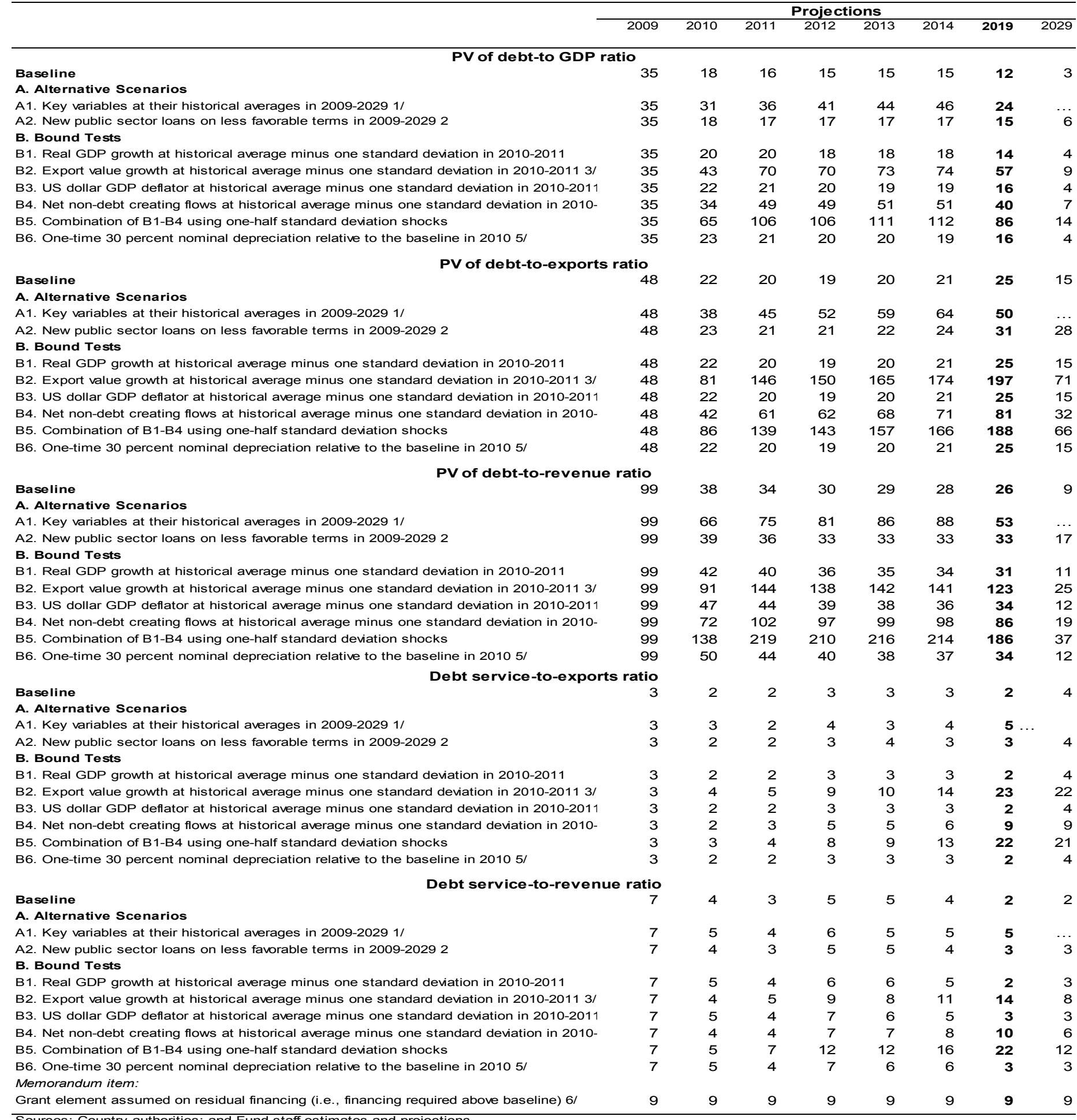
Sources: Country authorities; and Fund staff estimates and projections.

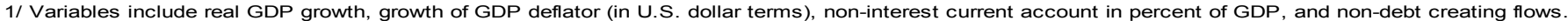



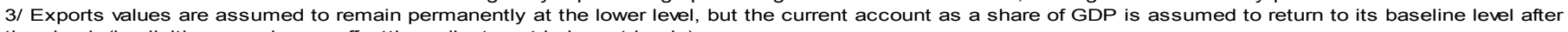
the shock (implicitly assuming an offsetting adjustment in import levels).

4/ Includes official and private transfers and FDI.

5/ Depreciation is defined as percentage decline in dollar/local currency rate, such that it never exceeds 100 percent.

6/ Applies to all stress scenarios except for A2 (less favorable financing) in which the terms on all new financing are as specified in footnote 2. 
Table 4. Republic of Congo: Sensitivity Analysis for Key Indicators of Public Debt, 2006-29 (In percent of GDP, unless otherwise indicated)

PV of Debt-to-GDP Ratio
Baseline
A. Alternative scenarios
A1. Real GDP growth and primary balance are at historical averages
A2. Primary balance is unchanged from 2009
A3. Permanently lower GDP growth $1 /$
B. Bound tests
B1. Real GDP growth is at historical average minus one standard deviations in 2010-20.
B2. Primary balance is at historical average minus one standard deviations in 2010-201.
B3. Combination of B1-B2 using one half standard deviation shocks
B4. One-time 30 percent real depreciation in 2010
B5. 10 percent of GDP increase in other debt-creating flows in 2010

PV of Debt-to-Revenue Ratio 2

\section{Baseline}

$\begin{array}{llllllll}32 & -51 & -103 & -157 & -215 & -269 & -535 & -640\end{array}$

\section{A. Alternative scenarios}

A1. Real GDP growth and primary balance are at historical averages

A2. Primary balance is unchanged from 2009

A3. Permanently lower GDP growth $1 /$

\section{B. Bound tests}

B1. Real GDP growth is at historical average minus one standard deviations in 2010-20.

B2. Primary balance is at historical average minus one standard deviations in 2010-201.

B3. Combination of B1-B2 using one half standard deviation shocks

B4. One-time 30 percent real depreciation in 2010

B5. 10 percent of GDP increase in other debt-creating flows in 2010

$\begin{array}{rrrrrrrr}11 & -23 & -50 & -80 & -111 & -142 & -244 & -212 \\ 11 & -12 & -24 & -55 & -88 & -119 & -227 & -227 \\ 11 & -15 & -31 & -62 & -94 & -125 & -227 & -206 \\ 11 & -3 & -32 & -62 & -94 & -126 & -236 & -236 \\ 11 & -17 & -44 & -75 & -106 & -137 & -246 & -241\end{array}$

\section{Debt Service-to-Revenue Ratio 2/}

Baseline

$\begin{array}{rrrrrrrr}11 & -17 & -35 & -55 & -76 & -97 & -173 & -205 \\ 11 & -12 & -26 & -42 & -59 & -76 & -134 & -129 \\ 11 & -24 & -50 & -81 & -113 & -145 & -259 & -249\end{array}$

\section{A. Alternative scenarios}

A1. Real GDP growth and primary balance are at historical averages

A2. Primary balance is unchanged from 2009

A3. Permanently lower GDP growth $1 /$

\section{B. Bound tests}

B1. Real GDP growth is at historical average minus one standard deviations in 2010-20.

B2. Primary balance is at historical average minus one standard deviations in 2010-201

B3. Combination of B1-B2 using one half standard deviation shocks

B4. One-time 30 percent real depreciation in 2010

B5. 10 percent of GDP increase in other debt-creating flows in 2010

$\begin{array}{rrrrrrrr}32 & -48 & -102 & -155 & -212 & -266 & -515 & -550 \\ 32 & -25 & -50 & -108 & -168 & -223 & -480 & -592 \\ 32 & -31 & -64 & -120 & -180 & -234 & -480 & -535 \\ 32 & -7 & -65 & -121 & -180 & -236 & -500 & -615 \\ 32 & -36 & -90 & -145 & -203 & -258 & -521 & -628\end{array}$

Sources: Country authorities; and Fund staff estimates and projections.

$1 /$ Assumes that real GDP growth is at baseline minus one standard deviation divided by the square root of the length of the projection period.

2/ Revenues are defined inclusive of grants. 